\title{
Understanding relations between pastoralism and its changing natural environment
}
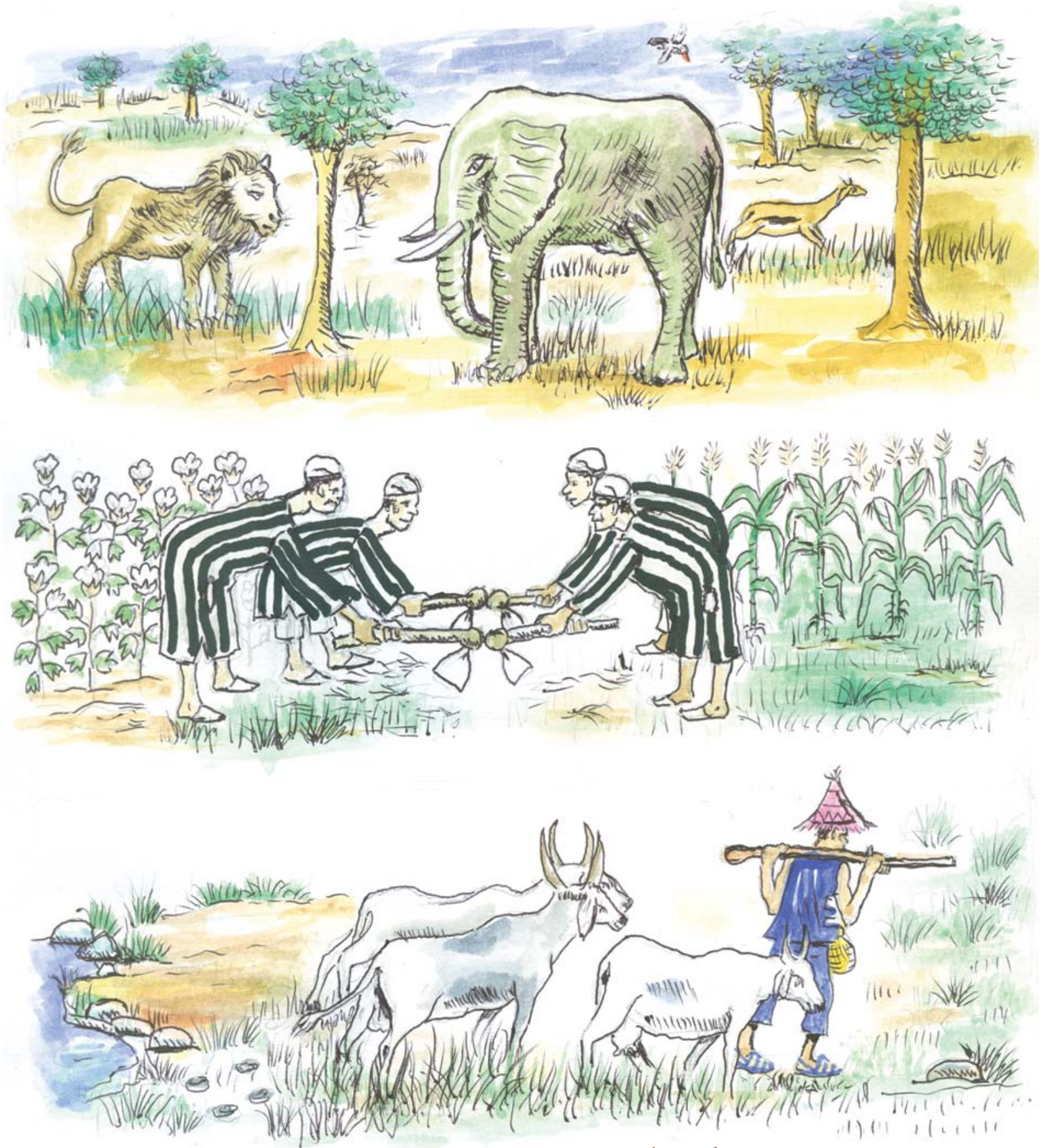

Charles Tamou 


\section{Understanding relations between pastoralism and its changing natural environment}

Charles Tamou 


\section{Thesis committee}

\section{Promotor}

Prof. Dr I.J.M. de Boer

Professor of Animal Production Systems

Wageningen University \& Research

\section{Co-promotors}

Dr S.J. Oosting

Associate professor, Animal Production Systems Group

Wageningen University \& Research

Dr R. Ripoll Bosch

Researcher, Animal Production Systems Group

Wageningen University \& Research

Prof. Dr I. Youssao Aboudou Karim,

Professor of Animal Genetics, Polytechnic School of Animal Production and Health University of Abomey-Calavi

\section{Other members}

Prof. Dr J.W.M. van Dijk, Wageningen University \& Research

Dr I.M.A. Heitkonig, Wageningen University \& Research

Dr M.A. Slingerland, Wageningen University \& Research

Dr A. Ayantunde, ILRI, Burkina Faso

This research was conducted under the auspices of the Graduate School of Wageningen Institute of Animal Sciences (WIAS) 


\title{
Understanding relations between pastoralism and its changing natural environment
}

Charles Tamou

\author{
Thesis \\ submitted in fulfilment of the requirements for the degree of doctor \\ at Wageningen University \\ by the authority of the Rector Magnificus, \\ Prof. Dr A.P.J. Mol, \\ in the presence of the \\ Thesis Committee appointed by the Academic Board \\ to be defended in public \\ on Monday 12 June 2017 \\ at 1.30 p.m. in the Aula.
}


Tamou, Charles

Understanding relations between pastoralism and its changing natural environment 164 pages.

PhD thesis, Wageningen University, Wageningen, the Netherlands (2017)

With references, with summaries in English and Dutch

ISBN 978-94-6343-155-2

DOI 10.18174/411051 
Aisha, the little girl who requested me to pledge the case of the Gah-Béri village from being displaced or burnt by the neighbouring crop farmers of Isséné village, following tension between the two communities in June 2014. 


$$
\text { - }
$$




\section{Abstract}

The competition for land has become an issue of major concern and cause of conflict, especially between pastoralists and crop farmers, but also between pastoralists and nature conservation institutions. The Biosphere Reserve of $\mathrm{W}$ in Benin Republic (WBR) and its surrounding lands are located in the agro-pastoral contact zone in West Africa, enabling competition for land, and affecting the relations between pastoralism and its environment. The general aim of this thesis, therefore, was to understand the relations between pastoralism and its changing natural environment. In terms of land use change, cropland area around WBR expanded, whereas grazing area reduced. Population growth and rising demand for food crops and cash crops were the indirect causes of this loss of grazing lands. Competing claims over land existed between crop farmers and pastoralists, among crop farmers, and among crop farmers, pastoralists, and the WBR authority due to past expropriation, unfair and incomplete implementation of the WBR regulations and the increasing shift of pastoral lifestyle to crop farming. In terms of effects of grazing on plant communities, highly grazed sites had more species diversity than lowly grazed sites. This suggests that the current level of grazing was not damaging plant communities' diversity. Annual species dominated the surveyed vegetation, suggesting that restoration of grazing lands with perennials requires human intervention. Herding involves taking decisions and moving of livestock in search for feed. Herding decisions are based on traditional ecological knowledge (TEK) of soil, forage and livestock. Pastoralists identified five different soils, which they selected for herding at different times of the year. Perennial grasses were perceived of high nutritional quality, whereas annuals were of low nutritional quality. Afzelia africana had high perceived quality for milk production, whereas Khaya senegalensis had the highest perceived quality for meat production, health and strength. In decision making for herding, pastoralists used a holistic approach, combining TEK about soil, vegetation and livestock, in a structured and prioritised reasoning. Changes in the pastoral system can lead to changes in desired livestock traits, which may lead to loss of indigenous breeds. Keteeji was valued for its endurance and tolerance to trypanosomiasis, Bodeeji was highly valued for endurance and Gudali was perceived of high value for meat and milk production, but of low value for endurance. To deal with the changing and unfavourable conditions of their environment, pastoralists preferred cattle breeds performing well on adaptive traits i.e. withstanding hunger, intelligence, and withstanding disease. Our results suggest that pastoralism is under pressure and that its survival depends on policies. In the pessimistic scenario, i.e. without any change, pastoralists will use, likely, the stepping-out strategy in the future. In the optimistic scenario, two possible institutional interventions could help maintaining pastoralism in the region: payments for ecosystem services provided by pastoralism, and association of pastoralism with nature conservation. In practice, however, the implementation of these two interventions is very challenging, which implies an increasing vulnerability of pastoralists and pastoral lifestyle. 


$$
\text { - }
$$




\section{Table of contents}

Chapter 1 General Introduction

Chapter 2 Pastoralists in a changing environment: the competition for grazing land in and around the W Biosphere Reserve, Benin Republic

Chapter 3 Effect of grazing on aboveground vegetation and soil seed banks in the W Biosphere Reserve, Benin Republic

Chapter 4 Traditional ecological knowledge underlying herding decisions of pastoralists

Chapter 5 Understanding roles and functions of cattle breeds for pastoralists in Benin

Chapter 6 General Discussion

Summary

References

Samenvatting

Acknowledgements

About the author

Publication list 


$$
\text { - }
$$




\section{Chapter 1}

\section{General Introduction}

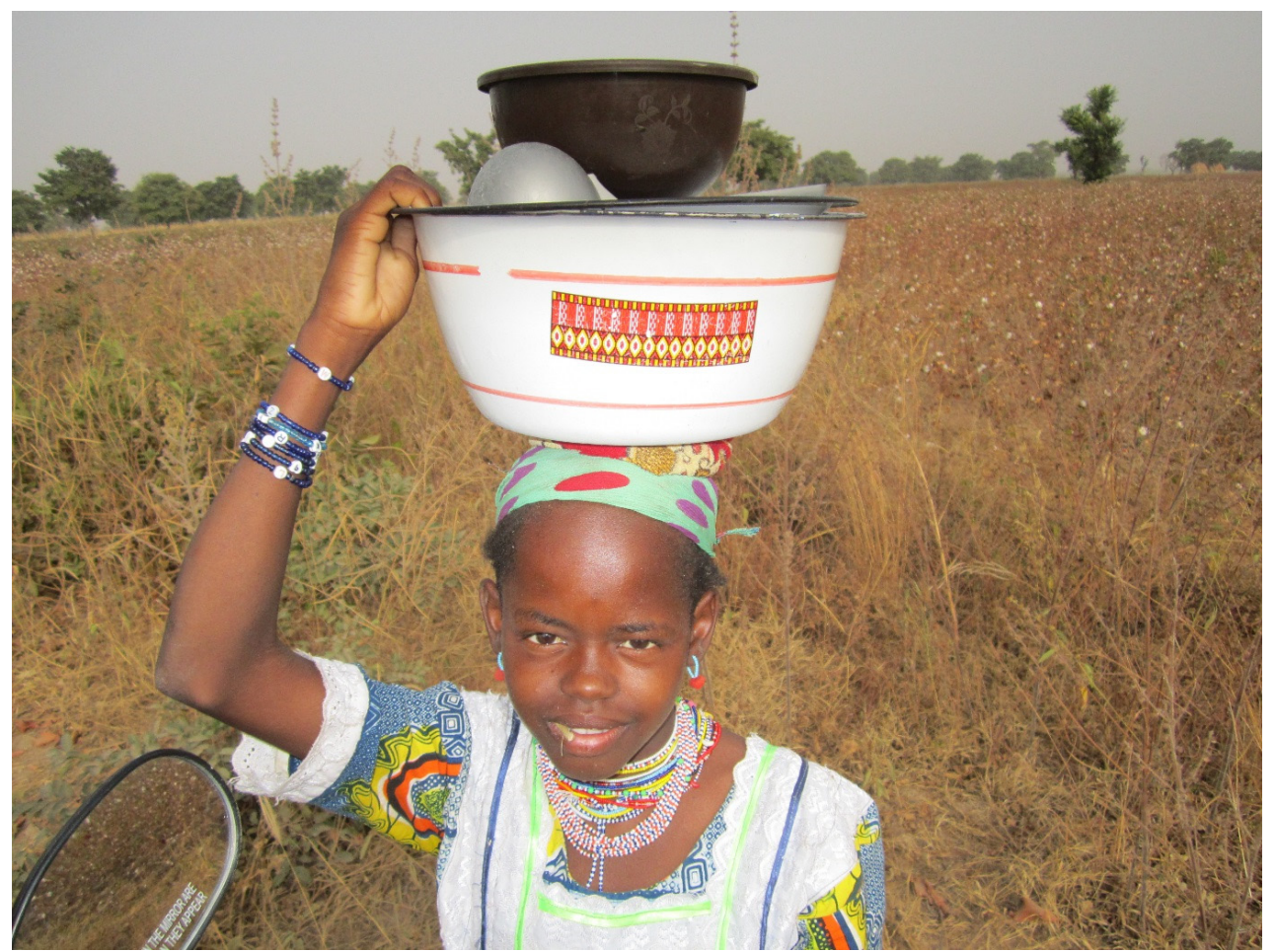

Aisha, a little Fulbe girl who already knows the challenges pastoralists are facing 


\subsection{Background}

Pastoralism is characterised by the movement of herds, in search for feed and water. It, therefore, has three components: people, livestock and natural pastures. Pastoralism is a predominant livelihood in less favoured landscapes, such as drylands, mountains and cold areas, where natural pastures are a primary resource. Drylands are traditionally used and managed by pastoralists, and host nearly one third of the world's human population and about half of the world's livestock (Boval et al., 2016; McDermott et al., 2010). The landscapes used by pastoralists are often less suitable for crop production. Drylands are regions of the world with an Aridity Index (i.e., the ratio of mean annual precipitation to mean annual potential evapotranspiration) below 0.65 (Safriel and Adeel, 2005). The climate in dryland regions, for example, is characterised by unpredictable droughts, and highly variable rainfall (Behnke et al., 1993; Whitford, 2002), with often poor soils (Penning de Vries et al., 1980). As a consequence, crop production is difficult and the availability of pasture resources is highly variable across time and space (Scoones, 1995). Mobility enables pastoralists to exploit this variability in pasture resources across time and space (Behnke et al., 1993; Mortimore, 2010). Pastoralism, therefore, is considered a well-adapted production system in the harsh dryland environment (Behnke et al., 1993). Moreover, livestock grazing is an efficient and reliable way to turn sunlight via vegetation and livestock into human food in the extreme and variable dryland environments (Reid et al., 2008).

Pastoralism takes diverse forms, depending on the location, the degree of livestock mobility, and the gender, ethnicity and wealth of the pastoralist (Ayantunde et al., 2011; Fratkin and Mearns, 2003; Moritz et al., 2009). Depending on the degree of livestock mobility, pastoralism is classified into four main categories: First, there is nomadic pastoralism, which is characterised by constant movement of the herds. Nomadism is for example found in Sudan and Saudi Arabia (Blench, 2001). According to Blench (2001), nomadic pastoralists are exclusive livestock keepers, who grow no crops and simply depend on the sale or exchange of animals and their products to obtain foodstuffs. Second, there is transhumant pastoralism, which involves seasonal (regular or irregular) movement of the herds between well-defined territories. Transhumance is the predominant form of pastoralism in West Africa (Slingerland, 2000; Thébaud and Batterbury, 2001). Transhumant pastoralists often 
General Introduction

have a permanent homestead, at which the older members of the community stay throughout the year. Transhumance is associated also with crops production, although primarily aimed at the herders' own use rather than the market (Blench, 2001). Third, there is transterminant pastoralism, which is characterised by short distance of (daily) movement by settled pastoralists. Transterminant pastoralism is wide spread and generally found in Mediterranean regions (González Álvarez, 2013). And fourth, there is agro-pastoralism, a mixed crop-livestock system with small herd sizes, which are insufficient to sustain the needs of the households. Agropastoralists' subsistence, therefore, is dependent on crop cultivation, providing more than $50 \%$ of the income. In agro-pastoralism, livestock moves in the vicinity of the farms and grazes on communal grazing lands, roadsides, and crop fields after harvest. Some scientists do not consider this fourth category as a form of pastoralism (Ayantunde et al., 2011; Swift, 1988; FAO, 2001), whereas others do (Moritz, 2003; Chang and Koster, 1994) since it involves livestock movement, no matter the size of the herd.

As a livestock production system, pastoralism involves the management, herding and care of domestic animals; generally ruminants, such as cattle, sheep, goats, camels, donkeys, yaks and llamas. Pastoralists keep about 35\% of the world's sheep, $23 \%$ of the goats, and $16 \%$ of the cattle and water buffalos. More than half of the world's pastoralists are found in Africa (55\%), followed by Asia (20\%), the Americas (15\%) and Australia (10\%) (Child et al., 1984). Products directly derived from pastoralists' herds are milk, meat and hides. In developing countries, with a pastoral-based economy, pastoralism contributes significantly to the agricultural gross domestic product (GDP), e.g. 80\% in Sudan, 84\% in Niger, 30\% in Mongolia (Davies and Hatfield, 2007), and, on average, 5.9\% in Benin, between 1995 and 2005 (MAEP, 2011). Pastoralists also contribute indirectly to the economy. Their activities vitalise local economies and result in employment for others. The pastoral system also supplies livestock markets with bulls, oxen, cows and small ruminants. Around livestock markets, other small businesses flourish, such as sale of food (by women), fodder, small equipment for crop farming, veterinary products, and use of trucks to transport livestock to those markets or even sale of bicycles and motorbikes. In addition, the local administration collect tax from livestock markets to support the budget of their municipality (e.g. in Benin, West Africa) (Tamou, 2011). Indirect products and services derived from pastoralists' activities are manure for crop 
Chapter 1

fertilisation and draught animals for ploughing and for transport in crop production. Moreover, pastoralism may also contribute to tourism and nature conservation, in terms of rangelands, and ecosystem processes and services that are enhanced or maintained by pastoralism (Davies and Hatfield, 2007).

With $55 \%$ of the world's pastoralists living there, Africa is the most important continent for pastoralism. The arid and semi-arid zones of sub-Saharan Africa account for $55 \%$ of the continent's area and hold $57 \%$ of domestic ruminants (Rutherford et al., 2006). In sub-Saharan Africa, about 25 million pastoralists and 240 million agro-pastoralists rely on livestock grazing for their livelihoods (Neely et al., 2009). According to the ruminant livestock association, the pastoral system in Benin involves more than 300,000 pastoralists (ANOPER, 2014). Livestock produced from the pastoral system plays an important role in the economy of these countries. For instance, between 1970 and 2000, livestock trade increased from USD 13 to 150 million in West Africa (Nugteren and Le Côme, 2016). Between 2009 and 2012, Nugteren and Le Côme (2016) reported USD 451 million as the total revenue of trade of pastoral livestock in both Mali and Burkina Faso. In Benin, according to (FAOSTAT, 2017), the gross production value of live cattle, sheep and goat, was estimated to be USD 100 million in 2013.

\subsection{Pastoralism as a knowledge system}

In the pastoral system, herders and their livestock access the resources of landscapes, by moving from one place to another. This mobility requires pastoralists to have a broad knowledge about soils, forages, livestock, climatic conditions and their interactions, as well as about social institutions. Pastoralism, therefore, is not only a livestock-based livelihood strategy, but also a recognized lifestyle with socio-cultural norms, beliefs and values, and traditional knowledge revolving around livestock (Davies et al., 2010; Niamir-Fuller, 1999). Through many years of experience in their environment, pastoralists have developed extensive knowledge, that guides a sustainable use and management of their surrounding resources (Blench, 2001). Such knowledge, referred to as traditional ecological knowledge (TEK), is defined as the cumulative body of knowledge, practices, and beliefs regarding the relations of living things to their environment, that evolves by adaptive processes, and is handed down through generations (Berkes et al., 2000). TEK of pastoralists in Africa has been extensively studied. Some studies showed pastoralists' TEK related to grassland 
General Introduction

degradation (Admasu et al., 2010; Behmanesh et al., 2015; Kassahun et al., 2008; Roba and Oba, 2009), others reported knowledge of grassland quality (Dabasso et al., 2012; Oba and Kaitira, 2006), or of botanic species diversity and their palatability for livestock (Ayantunde et al., 2008a; Davis, 2005; Oba and Kaitira, 2006). However, few studies attempt to integrate all this knowledge with regard to pastoralism. It is currently acknowledged that pastoralists' TEK is essential in preserving pastoralism and its cultural heritage. Moreover, policies and interventions related to range- and grassland use could benefit from understanding the TEK of pastoralists (Fratkin and Mearns, 2003).

Pastoralists not only have TEK about rangelands and their use, but also about their indigenous breeds. In the harsh environment of the drylands, pastoralists strive to produce from well adapted indigenous breeds. Pastoralists, therefore, contribute to maintaining animal genetic resources (Köhler-Rollefson et al., 2009; Hoffmann, 2011). In situ conservation of animal genetic resources builds on pastoralists, who are considered the creators and guardians of African livestock breeds (FAO, 2009; Köhler-Rollefson et al., 2009). Pastoralists have developed their indigenous breeds and have knowledge about these breeds. Within their own production systems, especially where environmental conditions are harsh, indigenous breeds are better than exogenous breeds, because of other qualities besides milk and meat production, such as resistance to trypanosomiasis or adaptation to heat stress (Anderson, 2003; Köhler-Rollefson et al., 2009; Ayalew et al., 2003).

\subsection{Competing claims for lands}

Competition for natural resources, especially land, has become an issue of major concern and cause of conflict (De Haan et al., 2016; Young et al., 2016), especially between pastoralists and crop farmers (De Haan et al., 2016; Fratkin and Mearns, 2003). Around the world, one of the major changes in dryland regions is the expansion of crop farming into drier areas over the last few decennia, which has pushed herders out of much of the wettest, most productive grazing lands over time (Reid et al., 2008). Such expansion of croplands occurs in the Guinean savannah zone of West Africa (MEA, 2005). Several forces (e.g. demographic, socio-economic, political, technological, cultural and/or biophysical) are driving this crop expansion and are consequently negatively affecting availability of and accessibility to pastoral resources in Africa (Reid et al., 2004). About 35 to 50\% of the wetter (semi-arid and 
dry sub-humid) portions of former grazing lands are now ploughed for irrigated and rainfed crops, and about 2 to $4 \%$ of the former grazing lands are now used for towns and cities (MEA, 2005). In Africa, croplands increased by 46 million hectares between 1985 and 2005, at the expense of natural vegetation and grazing lands (Foley et al., 2011). This trend of crop expansion into former grazing land continues today (Clerici et al., 2007). The encroachment of arable farming in pastoral ecosystems has led to a loss and fragmentation of pastoral lands, watering points and livestock routes (Reid et al., 2004).

Pastoralists not only compete for land with crop farmers, but also with nature conservation institutions (Reid et al., 2004). Nature conservation generally builds on protected areas. Original grazing lands of the Maasai, for example, have turned into nature reserves, such as the Maasai Mara and the Samburu National Park in Kenya, and the Serengeti National Park in Tanzania. Creation of these protected areas has reserved grazing lands for exclusive use by native biota (Fratkin and Mearns, 2003). Access to protected areas for grazing by domestic livestock, therefore, is illegal. However, due to shortage of feed and water (in the dry season) and to avoid damage to crop farms (in the rainy season), livestock move into protected areas. This has been seen in the Transfrontier Parks in Southern Africa (Murwira et al., 2012) and in the complex of the W-Arly-Pendjari in West Africa (Bouché et al., 2012; Convers et al., 2007).

\subsection{Problem statement}

The competition for natural resources, especially land, has become an issue of major concern and cause of conflict (De Haan et al., 2016; Young et al., 2016), especially between pastoralists and crop farmers (De Haan et al., 2016; Fratkin and Mearns, 2003), but also between pastoralists and nature conservation institutions (Reid et al., 2004). Governments and international development agencies have usually neglected pastoral populations and supported them with poorly designed interventions (De Haan et al., 2016). The FAO (2016) acknowledged that "pastoralists have traditionally suffered from poor understanding, marginalization and exclusion from dialogue". The encroachment of arable farming in pastoral ecosystems has led to a loss and fragmentation of pastoral lands, watering points and livestock routes (Reid et al., 2004). Hence, the mobile strategy used to sustain pastoral production in the drylands is being constrained (Thébaud and Batterbury, 2001; Ayantunde et al., 
General Introduction

$2008 \mathrm{~b})$. As a result, pastoralists are nowadays perceived as burden rather than support for larger societies (Leloup, 2006).

Pastoralism has been held responsible for rangeland degradation due to continuous grazing (Harris, 2010), which is in line with Garret Hardin's theory of the "tragedy of the commons" (Hardin, 1968). Rangeland degradation is defined as a decrease in plant species diversity, plant height, vegetation cover, and plant productivity (Ho and Azadi, 2010). This rangeland degradation can result in the reduction of palatable plant species, an increase in undesirable and unpalatable plants, and a depletion of soil quality (Mekuria et al., 2007). It is reported that about 31\% of Africa's pastures has been degraded (UNEP, 2008). Policies governing pastoralism and common opinions about grassland use have been influenced by Hardin's theory. To prevent possible overgrazing, governments initiated policies i.e. to privatise grasslands and to sedentarise pastoralists in order to limit the livestock pressure on grasslands. However, such measures have not always yielded satisfactory results and have often resulted in negative or disastrous consequences (De Haan et al., 2016; Fratkin and Mearns, 2003). On the one hand, sedentarisation resulted often in grassland being turned into croplands or in increased stocking rates with negative effects on plant communities (Ayantunde et al., 2011). On the other hand, it is questioned whether pastoralism can really be blamed for overgrazing and grassland deterioration. According to the intermediate disturbance hypothesis (IDH) (Connell, 1978), for example, certain grazing intensity could actually favour plant biodiversity, implying that pastoralism can play a synergetic role in rangeland and nature conservation. Milchunas et al. (1988), in an extended IDH, observed that it is not only grazing intensity that affects plant communities, but also gradients in precipitation and the evolutionary history of grazing. At the far end, the disequilibrium theory (Behnke et al., 1993) states that pastoral ecosystems in drylands are largely controlled by climatic variability and not so much by livestock. Hence, grazing and animal numbers are determined by grass productivity and have no causal effect on long term grass productivity (Behnke et al., 1993).

It is acknowledged that pastoralists possess detailed TEK about their grazing landscape, influenced and enhanced by such grazing landscapes. However, an important challenge for pastoralists is the loss and fragmentation of pastoral resources (Reid et al., 2004), which may change pastoralism. Changes in the pastoral 


\section{Chapter 1}

system and in pastoral lifestyle can therefore affects such TEK, and even result in loss of TEK. TEK of pastoralists in Africa has been extensively studied. Some studies focused on knowledge related to grassland degradation (Behmanesh et al., 2015; Kassahun et al., 2008; Roba and Oba, 2009), others on knowledge of grassland quality (Dabasso et al., 2012; Oba and Kaitira, 2006), or of botanic species diversity and their palatability for livestock (Ayantunde et al., 2008a; Davis, 2005; Oba and Kaitira, 2006). To our knowledge, TEK underlying herding decisions and the use of their grazing landscape by pastoralists have not been reported.

TEK does not only revolve about the grazing landscape, but also about the local animal breeds that can thrive in these harsh environments and make use of the grazing resources. Animal genetic resources (AnGR) are an essential part of the biological basis for world food security, and contribute to the livelihoods of over a billion people (FAO, 2007). At present, however, AnGR are being eroded, as a result of changes in agricultural practices, and in economic and environmental circumstances (Gibson et al., 2006). In situ conservation of AnGR in Africa builds on pastoralists, which are considered the creators and guardians of African livestock breeds, especially ruminants, such as cattle, sheep, goats, and camels (FAO, 2009; Köhler-Rollefson et al., 2009). At present, pastoralists' culture and lifestyle, however, is threatened, and consequently also their traditional way of herding (Catley et al., 2013; Thornton, 2010). Changes in pastoral life can lead to changes in desired traits, which may lead to loss of indigenous breeds (Hoffmann, 2010). This loss might compromise livelihoods of pastoralists and future improvement of their production systems (Van der Zijpp, 2011).

\subsection{Aim of this thesis}

The general aim of the study was "to understand relations between pastoralism and its changing natural environment”. To this end, I studied the W Biosphere Reserve (WBR) in northern Benin, where all issues and concerns presented in the previous sections occur.

\subsection{Context and description of the $W$ Biosphere Reserve}

The WBR and its surrounding land are located in the so-called agro-pastoral contact zone in West Africa (De Haan et al., 1990), implying that land is suitable for crop farming and pastoralism, potentially enabling competition for land. In, and especially 
in the periphery of the Biosphere Reserve of $\mathrm{W}$ in Benin Republic (WBR), some studies report an ongoing trend of land use change from a natural land cover (i.e. forest and savannah) to cropland (Avakoudjo et al., 2014; Clerici et al., 2007; Houessou et al., 2013). These studies focus on the regression of natural vegetation and the expansion of cropland, but little is said about the habitats and resources for pastoralists. The encroachment of arable farming in pastoral ecosystems has forced pastoralists to search for other grazing areas and eventually resulted in illegal grazing inside the reserve (Convers et al., 2007). As in several African countries, policies governing pastoralism in this area are still influenced by Hardin's theory (Hardin, 1968). The viewpoint and consequences for pastoralists seem to be ignored. A sustainable land use policy for area requires understanding the dynamics in land use and land use change, and providing voice to all actors involved, especially pastoralists. In this thesis, pastoralists involved in the study were either transterminant pastoralists, transhumant pastoralists, or both.

The name "W" originates from the W shape of the Niger River that borders the northern section of the Reserve (in Benin Republic). The WBR comprises about 56\% of the W Transboundary Biosphere Reserve located in the countries of Benin, Niger and Burkina Faso, and covers about $5632 \mathrm{~km}^{2}$ (see Figure 1). The WBR is located at $11^{\circ} 26^{\prime}$ to $12^{\circ} 26^{\prime} \mathrm{N}$ and $2^{\circ} 17^{\prime}$ to $3^{\circ}$ o5' $\mathrm{E}$. The natural vegetation consists of tree, shrub and woodland savannah, gallery forest and wetland. This vegetation allows the presence of wildlife valuable for conservation purposes, such as lions, cheetahs, elephants, buffaloes, waterbucks, monkeys and birds. The regional water supply comes from the Niger River and its tributaries: the Alibori, Mekrou, and Sota watercourses. The overall area is characterised by two main seasons: a rainy season from mid-May to October, with an average minimum daily temperature of $12{ }^{\circ} \mathrm{C}$, an average maximum daily temperature of $25^{\circ} \mathrm{C}$, and precipitation ranging from 700 to $1000 \mathrm{~mm}$; and a dry season from November to mid-May, with an average minimum daily temperature of $30{ }^{\circ} \mathrm{C}$, an average maximum daily temperature of $40{ }^{\circ} \mathrm{C}$ and hardly any precipitation (Billand et al., 2005). 


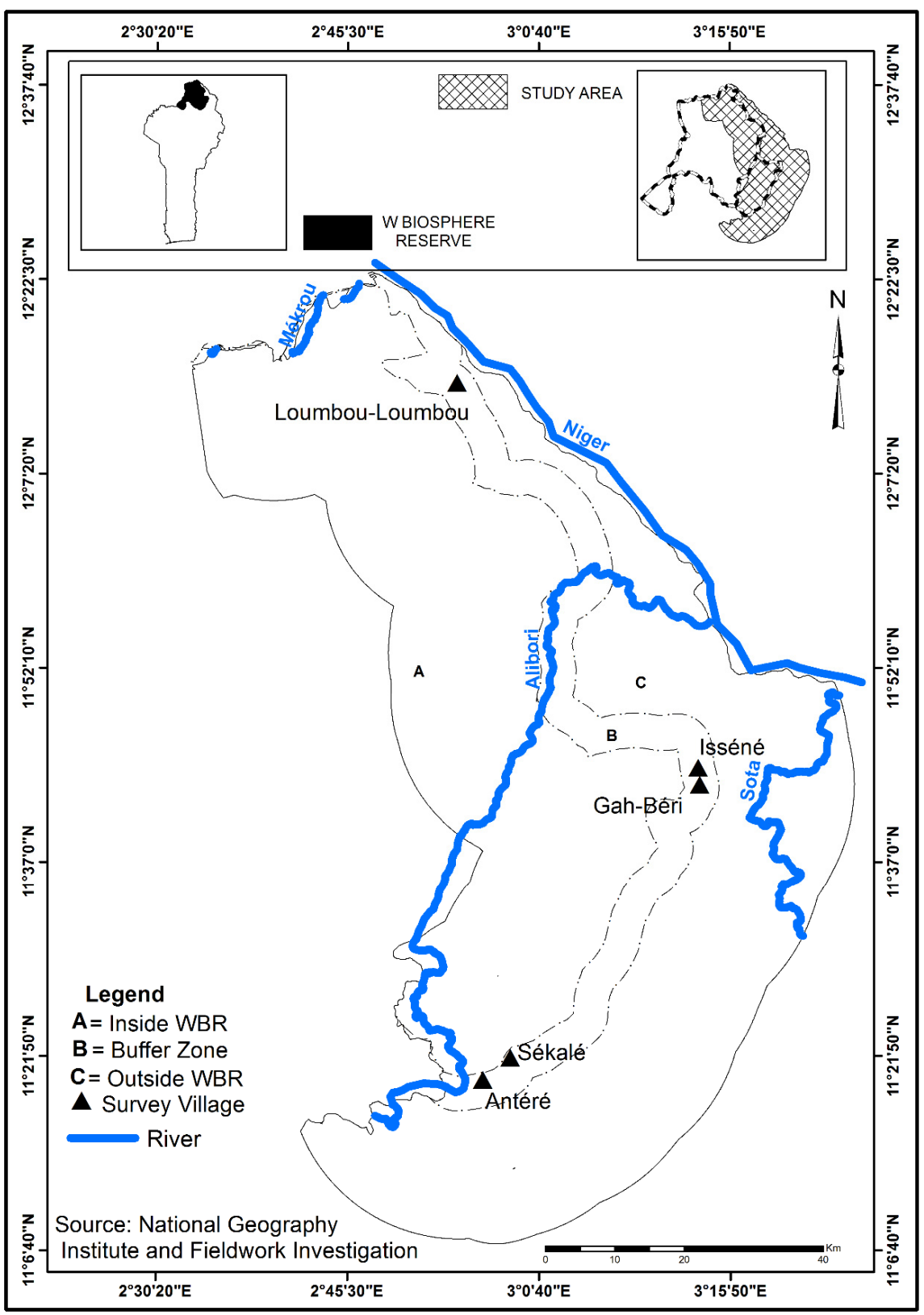

Figure 1. The W Biosphere Reserve (WBR) in Benin (small inset map left top corner), the study area relative to the Beninese section of the WBR (small inset map right top corner) and the study area. Villages Sékale (crop farmers) and Antéré (pastoralists) are in the southern agro-ecological zone, villages Isséné (crop farmers) and Gah-Béri (pastoralists) are in the mid agro-ecological zone and village Loumbou-Loumbou (crop farmers and pastoralists) is in the northern agro-ecological zone 
During the first part of the dry season, from November to February, a dry dusty wind blows through the North of Benin, also referred to as harmattan, which boosts the drying process of natural pastures. The harmattan facilitates burning of dried pasture, either from controlled or uncontrolled bush fire.

In Benin, the WBR is bordered by five districts, with a total of 759300 inhabitants (INSAE, 2013). In these districts, the main economic activities are crop farming and livestock production. Crop farmers get their main income from production of cereals (maize, sorghum, millet, rice), roots and tubers (yam, cassava, potato and sweet potato), legumes (groundnut, beans, soybean and bambara bean), vegetables (tomato, pepper, okra, pumpkin) and cotton, and possess oxen for ploughing. They belong to the following ethnic groups: Baatonu, Dendi, Monkole and Goumantche. In contrast, pastoralists obtain their main income from livestock and livestock products, and belong to the Fulbe ethnic group. The Fulbe pastoralists are dwellers of the districts surrounding the WBR and some of them come from the bordering countries Burkina Faso, Niger and Nigeria, during the dry season (Tamou, 2002). In this thesis, I refer to pastoralists as either transhumant pastoralists or transterminant pastoralists, or both

To prevent illegal activities in the WBR, such as clearing for cropping, grazing by livestock, poaching and fishing, rangers are hired and trained for patrolling inside the WBR. To engage the surrounding people in the co-management of the WBR, the Association Villageoise de Gestion des Réserves de Faune (AVIGREF; in English, Village Association of Wildlife Management) has been set in the bordering villages. Members of the AVIGREF are often former poachers and current crop farmers now engaged in the co-management of the WBR, by for example informing the authorities on illegal activities. AVIGREF members receive game meat and subsidies after each season of hunting and tourism.

\subsection{Thesis outline}

The aim of this thesis is to understand the relations between pastoralism and its changing natural environment in and around the W Biosphere Reserve (WBR) in northern Benin. The first step towards understanding these relations is to understand drivers of land use change and competition for land in and around the WBR. The aim of chapter 2, therefore, was i) to describe and analyse land use 
changes in order to understand their drivers, and ii) to describe and analyse the viewpoints of relevant stakeholders in order to understand the competition for land in and around the WBR. Data were collected from geographic information system tools, regional statistics, and community meetings and surveys with pastoralists, crop farmers and rangers of the WBR authority.

Subsequently, to understand pastoralism impact on plant communities, I assessed in chapter 3 the effect of grazing and its intensity on the plant community diversity; to our knowledge, this is unknown. The aim of chapter 3 , therefore, was to evaluate whether the present grazing regime in the bordering of and inside the WBR affects plant community diversity by addressing the following objectives i) to assess the effect of grazing intensity on plant community diversity in the aboveground vegetation; ii) to assess the effect of grazing intensity on seed abundance and species diversity in the soil seed bank; iii) to assess the effect of grazing intensity on similarity of species prevalence between aboveground vegetation and soil seed bank. We performed a plant inventory for the aboveground vegetation for sites with low and high grazing intensities, in eight sampling sites. A pot experiment with a randomized block design was used to study seed germination of the upper and deeper soil layers of soil seed banks collected at the same sites.

Herding is moving and grazing of livestock, in the grazing landscape consisting of soils, forages and livestock. Herding decisions are based on assessment of soil characteristics, forage characteristics and livestock characteristics. Understanding how such characteristics relate to location and moment of herding may give insight into how pastoralists use natural resources and may give scope for sustainable land use planning and grassland conservation. Chapter 4, therefore, had the following objectives: i) to inventorise and assess how pastoralists characterise quality of soils and forages in their environment, ii) to analyse how soil, forage and livestock characteristics relate to herding decisions and iii) to determine whether TEK underlying herding decisions differs across generations. Data were collected through rapid rural appraisals, focus groups and individual interviews with 72 pastoralists, belonging to three generations and three agro-ecological zones.

Finally, pastoralism is facing the loss and fragmentation of grazing lands, which might affect their production system. Changes in the pastoral system can lead to changes in desired traits, which may lead to loss of indigenous breeds. 
Understanding pastoralists' perception of their indigenous breeds and their associated desired traits is of importance in order to prevent loss of livestock diversity, and to improve future production systems. The objectives of chapter 5 were: i) to inventorise indigenous breeds of cattle and their traits, ii) to analyse pastoralists' preference for breeds and associated reasons, and iii) to determine whether knowledge about breed traits is existent in the younger generations. Data were collected through rapid rural appraisals, focus groups and individual interviews with 72 pastoralists, belonging to three generations and three agro-ecological zones. 


\section{Chapter 2}

Pastoralists in a changing environment: the competition for grazing land in and around the $W$ Biosphere Reserve, Benin Republic

Tamou C, Ripoll Bosch R, de Boer IJM, Oosting SJ

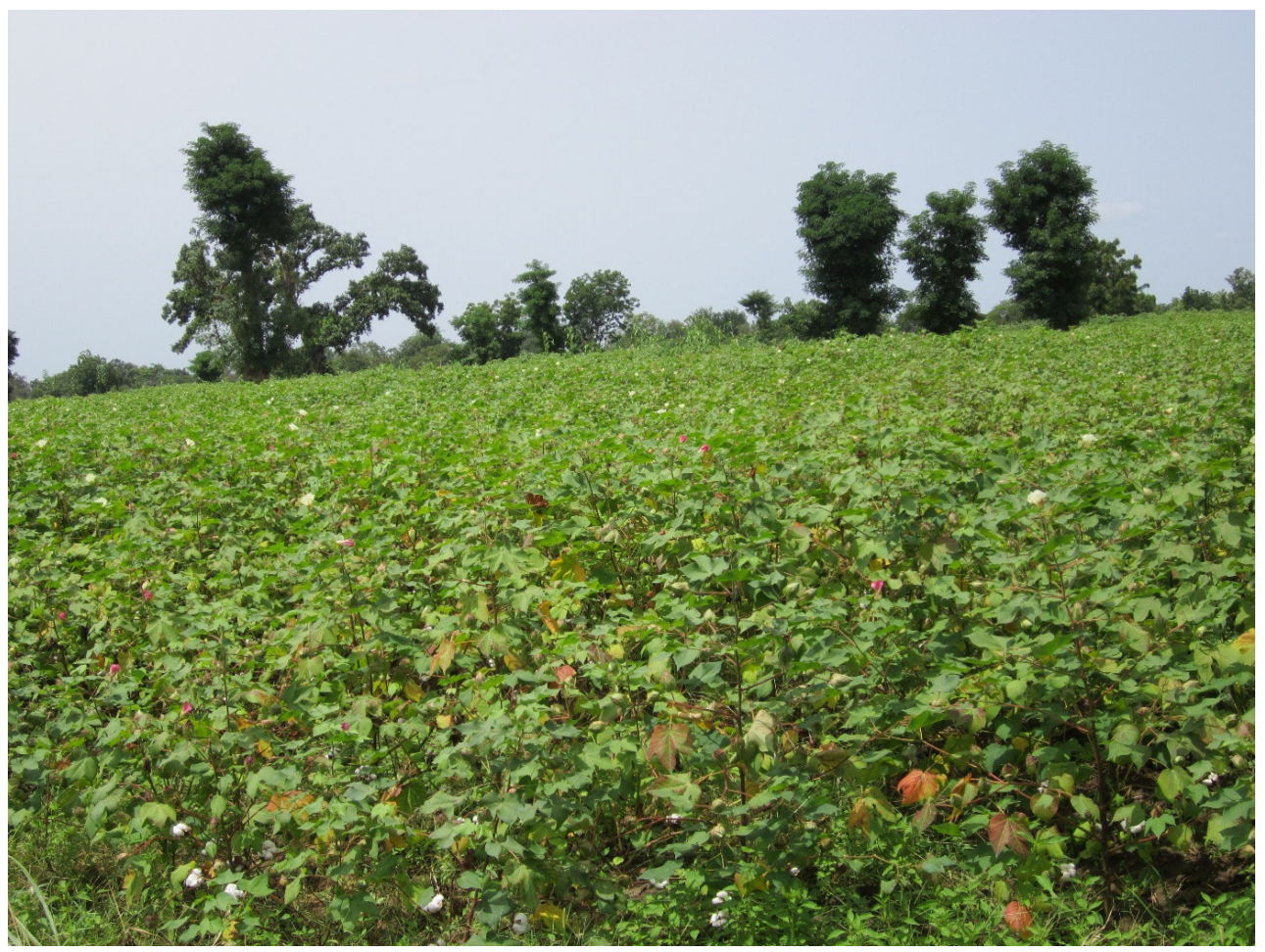

Cotton farm inside the WBR

Under revision at AMBIO. A journal of the Human Environment 


\begin{abstract}
Pastoralists face increasing competition for land with crop farmers and nature in and around the W Biosphere Reserve (WBR) in Benin. Our aim was to describe and analyse land use changes to understand their drivers, and to describe and analyse the viewpoints of relevant stakeholders to understand the competition for land. We collected quantitative and qualitative data about land use. Cropland area around WBR expanded, whereas grazing land area reduced. Population growth and rising demand for food crops, and government support to the cotton sector were indirect causes of grazing land reduction. Competing claims over land existed between crop farmers and pastoralists, among crop farmers, and among crop farmers, pastoralists, and WBR authorities based on past expropriation, unfair and incomplete implementation of the WBR regulations and the shifting lifestyle of pastoralists. Pastoralism is under so much threat that its survival depends on policies to protect grazing lands.
\end{abstract}

Key-words: competing claims, land use change, drivers, pastoralism, crop production, nature conservation 
Pastoralists in a changing environment

\subsection{Introduction}

Drylands host nearly one third of world's population, about half of the world's livestock and are traditionally used and managed by pastoralists (Boval et al., 2017; McDermott et al., 2010). In sub-Saharan Africa, for example, about 25 million pastoralists and 240 million agro-pastoralists rely on livestock grazing on drylands for their livelihoods (Neely et al., 2009).

Dryland ecosystems are characterised by unpredictable droughts, erratic and highly variable rainfall (Behnke et al., 1993) and often poor soils (Penning de Vries et al., 1980). In consequence, the availability of pasture resources is highly variable across time (seasons) and space (Scoones, 1995). Mobility enables pastoralists to exploit this variability in pasture resources across time and space (Behnke et al., 1993; Mortimore, 2010). Pastoralism, however, is not only a livestock-based livelihood strategy, but a recognized lifestyle with socio-cultural norms, beliefs and values, and traditional knowledge revolving around livestock (Davies et al., 2010; Niamir-Fuller, 1999).

Despite the vital contribution of pastoral systems to food security and their ability to produce and thrive in lands unfavourable to agriculture (De Haan et al., 2016), pastoralism and pastoralist's lifestyle around the world are under pressure (Catley et al., 2013; Thornton, 2010) and in persistent state of crisis (De Haan et al., 2016); more than ever before (Fratkin and Mearns, 2003). Several driving forces (e.g. demographic, socio-economic, political, technological, cultural and/or biophysical) are hindering the availability and the accessibility of pastoral resources in Africa (Reid et al., 2004). In Africa, agricultural lands increased by 66 million hectares between 1985 and 2005 (Foley et al., 2011), at the expense of mainly forests, woodlands, and savannahs (Chang et al., 2016; Gibbs et al., 2010). The encroachment of arable farming in pastoral ecosystems has led to a loss and fragmentation of pastoral lands, watering points and livestock routes (Reid et al., 2004). Hence, the mobile strategy used to sustain pastoral production in the drylands is being constrained (Thébaud and Batterbury, 2001; Ayantunde et al., 2008), and the access to uncultivable lands, fallows and roadsides in the wet season hampered (Ayantunde et al., 2008; Bassett and Turner, 2007). As a result, pastoralists are nowadays perceived as a burden rather than as support for larger societies (Leloup, 2006). 
The competition for natural resources, especially land, has become an issue of major concern and cause of conflicts (Young et al., 2016; De Haan et al., 2016), especially between pastoralists and crop farmers (De Haan et al., 2016; Fratkin and Mearns, 2003), but also between pastoralism and nature conservation (Reid et al., 2004). In general, pastoral communities are among the most politically and socially marginalized. Governments and international development agencies have usually neglected pastoral populations and supported them with poorly designed interventions (De Haan et al., 2016). The FAO (2016) acknowledged that "pastoralists have traditionally suffered from poor understanding, marginalization and exclusion from dialogue". Therefore, policy interventions aimed at pastoralists have often resulted in negative or disastrous consequences (Fan et al., 2014; Fratkin and Mearns, 2003). A sustainable land use policy for the drylands requires understanding the dynamics in land use and land use change in the area of concern, and providing voice to all actors involved, especially pastoralists. Nevertheless, only limited observational or experimental research has been conducted on the loss or fragmentation of grasslands caused by human action (McGarigal and Cushman, 2002). Very few studies focus on the range of forces that cause loss and fragmentation of grazing lands (Reid et al., 2004), and pastoralists perspectives have been usually scorned (De Haan et al., 2016; Fratkin and Mearns, 2003).

In, and especially in the periphery of the $\mathrm{W}$ Biosphere Reserve (WBR) in Benin Republic, some studies report an ongoing trend of land use change from a natural land cover (i.e. forest and savannah) into cropland (Avakoudjo et al., 2014; Clerici et al., 2007; Houessou et al., 2013). These studies focus on the regression of natural vegetation and the expansion of cropland, but little is said about the habitats and resources for pastoralists. The viewpoints of and the consequences for pastoralists seem to be dismissed. Moreover, there is little understanding of the underlying drivers of land use change. The land uses and the competing claims among stakeholders (i.e. pastoralists, crop farmers and nature conservation institutions) in the region of the WBR remain poorly studied. Therefore, the aim of this study was, i) to describe and analyse land use changes to understand their drivers, and ii) to describe and analyse the viewpoints of relevant stakeholders understand the competition for land in and around the WBR. The study approach combines geographic information system tools, regional statistics and surveys with the main local land users. 
Pastoralists in a changing environment

\subsection{Material and methods}

\subsubsection{Study area description}

This study was carried out in the region of the WBR, in northern Benin (Figure 1). The WBR comprises about $56 \%$ of the W Transboundary Biosphere Reserve located in the countries of Benin, Niger and Burkina Faso, and covers about $5632 \mathrm{~km}^{2}$. The WBR is located at $11^{\circ} 26^{\prime}$ to $12^{\circ} 26^{\prime} \mathrm{N}$ and $2^{\circ} 17^{\prime}$ to $3^{\circ} \mathrm{O} 5^{\prime} \mathrm{E}$. The natural vegetation consists of tree, shrub and woodland savannah, gallery forest and wetland. This vegetation allows the presence of wildlife valuable for conservation purposes, such as elephants, lions, buffaloes, cheetahs, waterbucks, monkeys, and various birds. The regional water supply comes from the Niger River and its tributaries: the Alibori, Mekrou, and Sota watercourses. The overall area is characterised by two main seasons: a rainy season from mid-May to October, with an average minimum daily temperature of $12{ }^{\circ} \mathrm{C}$, an average maximum daily temperature of $25^{\circ} \mathrm{C}$, and precipitation ranging from 700 to $1000 \mathrm{~mm}$; and a dry season from November to mid-May, with an average minimum daily temperature of $30^{\circ} \mathrm{C}$, an average maximum daily temperature of $40{ }^{\circ} \mathrm{C}$ and hardly any precipitation (Billand et al., 2005). During the first part of the dry season, from November to February, a dry dusty wind blows through the North of Benin, also referred to as harmattan, which boosts the drying process of natural pastures. The harmattan facilitates burning of dried pasture, either from controlled or uncontrolled bush fire.

In Benin, the WBR is bordered by five districts, with a total of 759300 inhabitants (INSAE, 2013). In these districts, the main economic activities are crop farming and livestock production. The WBR and its surrounding land are located in the so-called agro-pastoral contact zone in West Africa (De Haan et al., 1990), implying that land is suitable for crop farming and livestock farming, potentially enabling competition for land. Crop farmers get their main income from production of cereals (maize, sorghum, millet, rice), roots and tubers (yam, cassava, potato and sweet potato), legumes (groundnut, beans, soybean and bambara bean), vegetables (tomato, pepper, okra, pumpkin) and cotton, and possess oxen for ploughing. They belong to the following ethnic groups: Baatonu, Dendi, Monkole and Goumantche. In contrast, pastoralists obtain their main income from livestock and livestock products, and belong to the Fulbe ethnic group. The Fulbe pastoralists are dwellers of the districts 


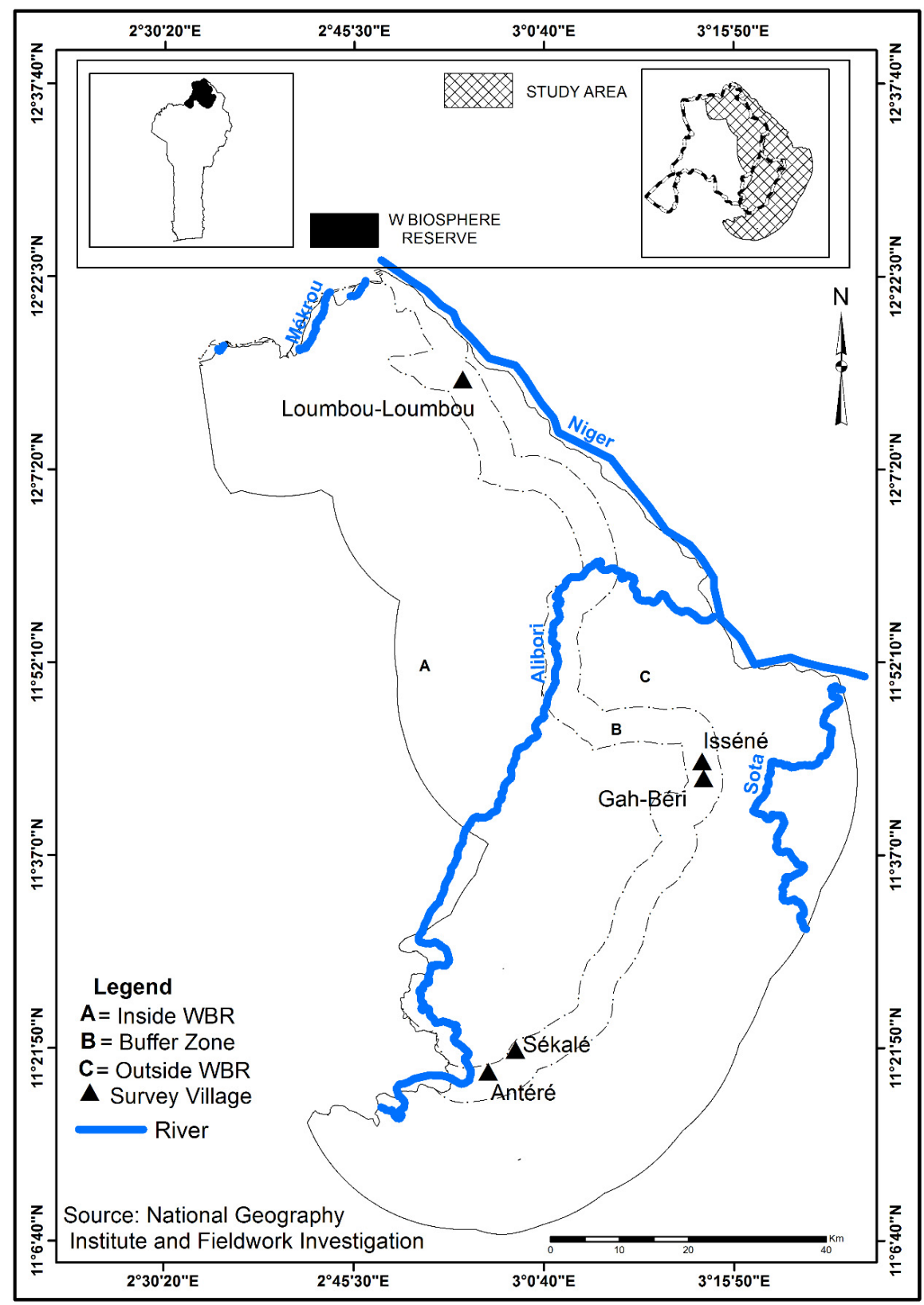

Figure 1. The W Biosphere Reserve (WBR) in Benin (small inset map left top corner), the study area relative to the Beninese section of the WBR (small inset map right top corner) and the study area. Villages Sékalé (crop farmers) and Antéré (pastoralists) are in the southern agro-ecological zone, villages Isséné (crop farmers) and Gah-Béri (pastoralists) are in the mid agro-ecological zone and village Loumbou-Loumbou (crop farmers and pastoralists) is in the northern agro-ecological zone 
Pastoralists in a changing environment

surrounding the WBR and some of them come from the bordering countries Burkina Faso, Niger and Nigeria, during the dry season (Tamou, 2002).

To prevent illegal activities in the WBR, such as clearing for cropping, grazing by livestock, poaching and fishing, rangers are hired and trained for patrolling inside the WBR. To engage the surrounding people in the co-management of the WBR, the Association Villageoise de Gestion des Réserves de Faune (AVIGREF; in English, Village Association of Wildlife Management) have been set in the bordering villages. Members of the AVIGREF are often former poachers and current crop farmers now engaged in the co-management of the WBR, by for example informing the authorities on illegal activities. AVIGREF members receive game meat and subsidies after each season of hunting and tourism.

\subsubsection{Data collection and analysis}

To fulfil our objectives, data were collected via Geographic Information Systems (GIS) tools, from regional statistics and through surveys.

\subsubsection{Data collected via GIS}

To analyse changes in land use in and around the WBR, via GIS tools, we defined three relevant land segments based on DeFries et al. (2005) and Clerici et al. (2007) (Figure 1):

- inWBR: the land segment inside the WBR, on the west side of the WBR boundary with a width of $20 \mathrm{~km}$;

- buffer zone: the land segment of $5 \mathrm{~km}$ width set by WBR authorities located outside the WBR, on the eastside of the WBR boundary; people are allowed to use this land segment under certain conditions, such as payment of fees for crop farming, grazing, or harvesting of non-timber forest products (NTFP). One has to strictly use the sub-zone for what it has been allowed for, i.e. crop farming, grazing or NTFP harvesting;

- outWBR: the land segment of $20 \mathrm{~km}$ width located in the surrounding lands outside WBR, east of the buffer zone.

We used the satellite images Landsat-8/LDCM (Landsat Data Continuity Mission) from 2014 and we identified four relevant classes using the standard supervised maximum likelihood technique (Richards, 2013): 
- Cropland: cultivated land with food crops (cereals, roots and tubers, and vegetables) and cash crops;

- Forest: land with closed forest canopy cover, either along rivers (gallery forest) or elsewhere (woodland);

- Savannah: land dominated by grass or herbaceous plants, often associated with sparse shrubs; and

- Wetland: land comprising water bodies such as rivers, ponds and streams, as well as lands along such water bodies.

The Kappa value for the land cover and land use classification was 0.96 for 2014, meaning a substantial to almost perfect agreement in the classification of the land use patterns (Viera and Garrett, 2005) .

Land use data obtained through GIS tools were analysed by comparing the area of each land use classes across the land segments.

\subsubsection{Secondary data collected from regional statistics}

To describe the dynamics of the cultivated lands, the livestock numbers and the human population, we selected three of the five administrative districts (Karimama, Malanville, Kandi) bordering the north, the east and the south part of the WBR. We collected data of land use, and human and livestock population size from regional statistics, which we refer to as secondary data. Data about cultivated land for food crops and cash crops (cotton) were derived from the database of the Centre d'Action Régionale pour le Développement Rural (CARDER, in English Agricultural extension services) of the province of Alibori in which the study was located. Livestock data were cattle numbers of the resident pastoralists (no distinction between the ages of the animals) and were derived from the reports of the vaccination campaigns by the Regional Office of Livestock in the province of Alibori. We did not collect data of transhumant pastoralists and their herds.

To assess the population density on cultivated land (person/ha) from regional statistics and human population, we have considered the census data of 1992, 2002 and 2013 and the cultivated land of 1997 to 2013. Since we did not have data for 1997, we estimated the human population of that year according to the formula:

$P_{t}=P_{l}(1+r)^{z}($ Swanson and Tayman, 2012) 
Pastoralists in a changing environment

where $P_{t}$ is the population to be estimated at the time $t$ in year, $P_{l}$ is the population of the previous census year, $r$ is the geometric growth rate of the population between census years, which was 3.3 \% between 1992 and 2002 (INSAE 2013), and $z$ is the number of years between the previous census year and the year $t$ of estimation.

\subsubsection{Data collected through surveys}

To analyse the competing claims for land by the stakeholders, information was collected through community meetings and individual interviews with land users in the selected villages. Survey data collection was carried out in November to December 2014 and in April 2015. It started with a desk study and informal (without interview guide) interviews with officials from the WBR, the office of livestock management and the agricultural extension services, dealing with land use issues. We conducted an exploratory study in 15 villages in outWBR and the buffer zone. Out of these villages, we selected one in each district, being representative with regard to ethnicity, climatic conditions and cropping system. In each of the selected villages we performed community meetings and we held individual interviews with crop farmers, pastoralists, AVIGREF members and rangers (Table 1).

Table 1. Number of interviewees per stakeholder group and per village

\begin{tabular}{lllll}
\hline district & $\begin{array}{l}\text { Kandi } \\
\text { (south of WBR) }\end{array}$ & $\begin{array}{l}\text { Malanville } \\
\text { (east of WBR) }\end{array}$ & $\begin{array}{l}\text { Karimama } \\
\text { (north of WBR) }\end{array}$ & total \\
\hline village & Sekale / Antere & Issene / Gah-Beri & $\begin{array}{l}\text { Loumbou- } \\
\text { Loumbou }\end{array}$ & \\
\hline $\begin{array}{l}\text { stakeholders } \\
\text { crop farmers }\end{array}$ & 10 & & & 30 \\
pastoralists & 10 & 10 & 10 & 31 \\
AVIGREF & 5 & 11 & 10 & 18 \\
rangers & 3 & 8 & 5 & 7 \\
\hline
\end{tabular}

We held six community meetings separately with crop farmers and with pastoralists. Participants of the community meetings were elders and member of the village council. Community meetings were facilitated by the researcher using a discussion guide containing questions in French that were translated into the local language by a trained interpreter. The questions in the discussion guide covered the following items: access to land, competing claims, conflicts and their causes, relationships between crop farmers and pastoralists, the use of the buffer zone and the history of the settlement of villages. Community meetings lasted from 1.5 hour to 2 hours. 
We conducted individual interviews with crop farmers, pastoralists, members of the AVIGREF and rangers using semi-structured questionnaires with two sections. The first section was about the socio-economic characteristics, such as household size, farm type and land size, and livestock species and herd size. Using the four-point scale zero, small, medium or large, the second section of the questionnaire addressed quantity of change in land use during the last two decades (1994-2014), i.e. agricultural land availability in the outWBR. Next to that, using the four-point scale increased, decreased, no change or don't know, we then addressed the change of cropland area, area of grazing land and area of watering points (natural or manmade ponds used for livestock watering). Finally, we addressed the main possible causes for changes in cropland area, grazing land area and watering points through an open question. Participants of the individual interviews were those willing to share their views on the land use issues. Individual interviews lasted between 45 minutes and one hour. The researcher asked the questions in French and the questions were then translated into the local language by a trained interpreter.

Community meeting data were analysed by coding, summarizing and categorizing respondents' opinion in order to find patterns. Information gained from the individual surveys was analysed using descriptive statistics and analysis of variance. Stakeholders' perception of change in land use and their related drivers were analysed with frequency and corresponding percentage, whereas means of socioeconomic characteristics were tested for difference. Where appropriate, the post-hoc Tukey test was used for significant difference between means. All statistical analyses were done using the statistical software R 3.2.2.

\subsection{Results}

\subsubsection{Land use}

In 2014, savannah and forest covered about $90 \%$ of the land in inWBR and only $9 \%$ of the land was used for crop production (Table 2). In contrast, about two thirds of the land were used for crop production in the buffer zone (i.e. 66\%) and outWBR (i.e. $64 \%$ ), and only $25 \%$ of the land in the buffer zone and $30 \%$ of the land in outWBR was covered with savannah and forest. Since livestock only graze in the savannah and forest, feed resources for livestock are relatively limited in the buffer zone and in the outWBR. 
Pastoralists in a changing environment

Table 2. Land use (in ha and \%) per land segment in 2014

\begin{tabular}{|c|c|c|c|c|c|c|}
\hline \multirow[b]{3}{*}{ land use } & \multicolumn{6}{|c|}{ land segment } \\
\hline & \multicolumn{2}{|l|}{ inWBR } & \multicolumn{2}{|c|}{ buffer zone } & \multicolumn{2}{|c|}{ outWBR } \\
\hline & ha & $\%$ & ha & $\%$ & ha & $\%$ \\
\hline cropland & 27811 & 9 & 60891 & 66 & 182370 & 64 \\
\hline savannah & 215942 & 73 & 20604 & 22 & 67107 & 24 \\
\hline forest & 50007 & 17 & 2482 & 3 & 17679 & 6 \\
\hline wetlands & 3678 & 1 & 8266 & 9 & 1629 & 6 \\
\hline
\end{tabular}

\subsubsection{Results of secondary data}

\subsubsection{Cultivated lands}

Figure 2 shows cultivated land used for production of food and cash crops between 1997 and 2013. In this period, the total amount of the cultivated land used for production of food and cash crops nearly doubled from 92000 ha to 185000 ha, where more land is used for food crop than for cash crop production.

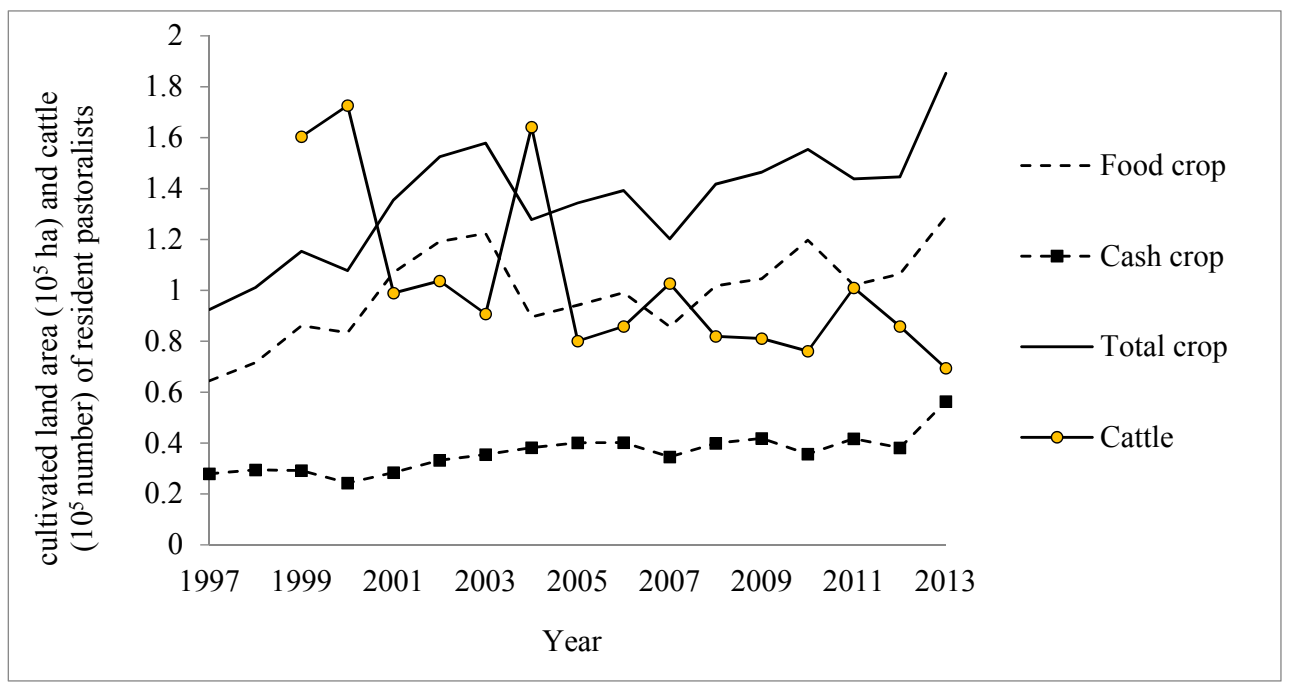

Figure 2. Development of cultivated land area and cattle numbers of resident pastoralists and of crop farmers

\subsubsection{Cattle population}

We distinguished two types of cattle farming in the study area: cattle farming by local pastoralists, and oxen kept by crop farmers. In Figure 2, local livestock is the sum of the number of cattle of resident pastoralists and the number of oxen (around 10\% of the total) kept by crop farmers. Overall, the number of cattle decreased by more than half between 1997 and 2013. Information collected during surveys seems to indicate 
that many herds of cattle left the region, because of the difficulty to feed livestock with natural pasture.

\subsubsection{Human population and population density on cultivated land}

The human population more than doubled, from about 202000 in 1997 to 414000 in 2013 (fig 3.). The population density on cultivated land remained relatively stable between the considered periods and was 1.5 to 2.2 people ha-1.

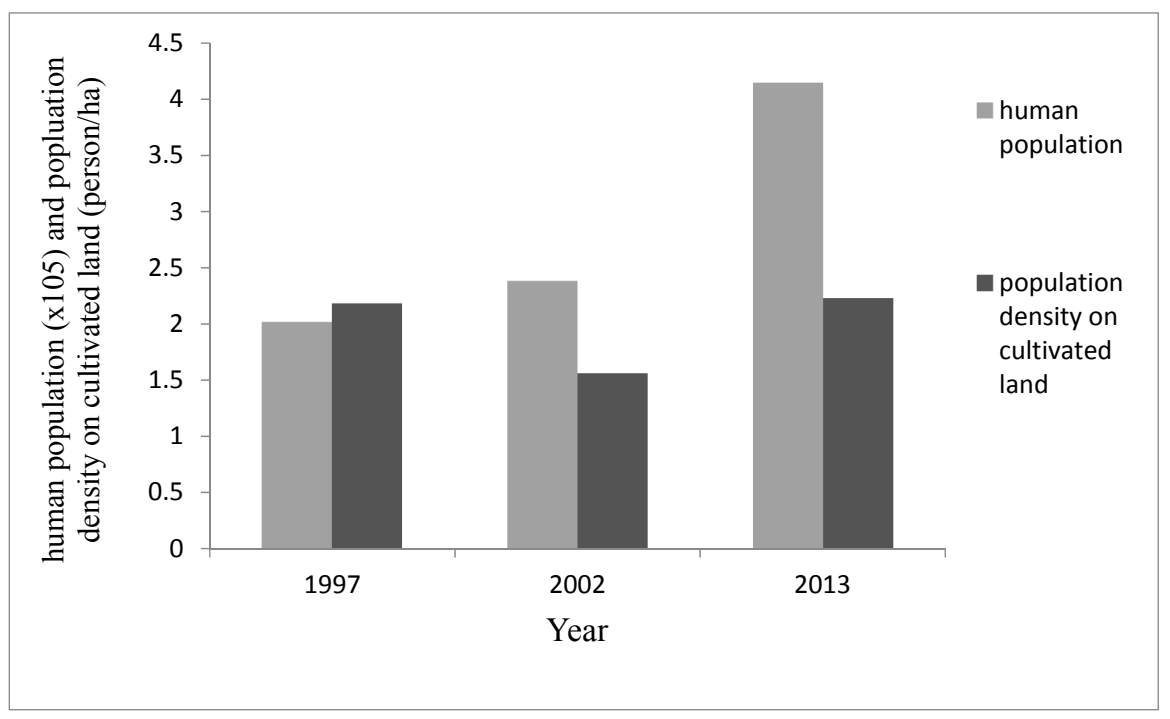

Figure 3. Development of human population and population density on cultivated land

\subsubsection{Results from surveys}

\subsubsection{Socioeconomic characteristics of stakeholders}

Crop farmers, pastoralists and AVIGREF members were all involved in crop and livestock farming (Table 3). The area of crop land was larger for crop farmers and AVIGREF members than for pastoralists, whereas the number of cattle was higher for pastoralists than for crop farmers and AVIGREF members. The number of goats was lowest for crop farmers, while the number of sheep did not differ between stakeholders. These results indicate that there are no strict crop farmers or livestock farmers in the study area. All the land users practised mixed farming, where cropping was the most important activity for crop farmers and AVIGREF members, and livestock farming was the most important activity for pastoralists. 
Pastoralists in a changing environment

Table 3. Means (and standards deviation) of socioeconomic characteristics of the stakeholders

\begin{tabular}{lllll}
\hline & \multicolumn{2}{l}{ stakeholders } & & \\
\cline { 2 - 4 } $\begin{array}{llll}\text { socioeconomic } \\
\text { characteristics }\end{array}$ & $\begin{array}{l}\text { pastoralists } \\
\mathrm{n}=31\end{array}$ & $\begin{array}{l}\text { crop farmers } \\
\mathrm{n}=30\end{array}$ & $\begin{array}{l}\text { AVIGREF } \\
\text { members } \\
\mathrm{n}=18\end{array}$ & P-value \\
\hline food crop area (ha) & $3.3(1.85)^{\mathrm{b}}$ & $8.2(6.18)^{\mathrm{a}}$ & $8.1(4.85)^{\mathrm{a}}$ & $<0.001$ \\
cash crop area(ha) & $0.8(1.03)^{\mathrm{b}}$ & $6.6(7.00)^{\mathrm{a}}$ & $5.4(4.79)^{\mathrm{a}}$ & $<0.001$ \\
number of cattle & $41(24.7)^{\mathrm{a}}$ & $5(3.2)^{\mathrm{b}}$ & $6(6.9)^{\mathrm{b}}$ & $<0.001$ \\
number of goats & $18(20.4)^{\mathrm{a}}$ & $4(4.2)^{\mathrm{b}}$ & $8(16.3)^{\mathrm{a}}$ & 0.003 \\
number of sheep & $9(10.2)$ & $4(3.5)$ & $9(14.4)$ & 0.7 \\
household size (no.) & $11(3.6)$ & $12(8.5)$ & $13(4.8)$ & 0.5 \\
\hline
\end{tabular}

Mean values in the same socioeconomic characteristic with different letters are different $(\mathrm{P}<0.05)$

\subsubsection{People's perception of the drivers leading to an expansion of cropland and a reduction in pastureland and watering points}

In outWBR, 78 out of 86 respondents argued that no new agricultural land was available, 6 respondents stated that new agricultural land availability was small, and 2 respondents stated that new agricultural land availability was medium. Moreover, 79 out of these 86 respondents indicated that cropland expanded over the past 20 years. Population growth was seen as the major cause for this expansion, followed by increased incentives for cotton cultivation (Table 4). Additional factors perceived to drive expansion of crop land were a decline in soil fertility and the shifting from production of food crops for subsistence to a more market-oriented production.

Eighty-four out of the 86 respondents perceived that the grazing area had declined over the past 20 years. Clearing of pasture land for crop farming was perceived as the main cause of this decline in grazing area, while some crop farmers also mentioned the increase in number of livestock (Table 4). Additional factors perceived to drive this decline in grazing area were herbicide use, cotton cultivation, availability of tractors for ploughing, and cropping in the riverbanks. Indeed, herbicide use facilitates the cleaning of weeds on fields, and boosts the expansion of crop land. Cotton cultivation is subsidised by the government and its expansion is supported for the economic growth of the country. In the dry season, riverbanks of Niger are increasingly used for production of vegetables and rice, creating competition with livestock who grazed these areas previously. Tractors facilitate the ploughing of farm fields, and, as such stimulate cultivation of additional cropland; their use, moreover, is supported by the government. 
A reduction in size of watering points for livestock was perceived by 78 out of 86 respondents. This reduction was perceived to mainly result from the increase in crop farming in riverbanks, and near ponds and streams (Table 4). A decrease in precipitation and siltation of ponds and streams were perceived as additional explanatory factors.

Table 4. Frequency of drivers mentioned by the stakeholders for cropland expansion, pastureland decrease and the reduction of watering points

\begin{tabular}{|c|c|c|c|c|c|}
\hline \multirow[b]{2}{*}{ drivers } & \multicolumn{5}{|l|}{ Stakeholders } \\
\hline & pastoralists & $\begin{array}{l}\text { crop } \\
\text { farmers }\end{array}$ & $\begin{array}{l}\text { AVIGREF } \\
\text { members }\end{array}$ & rangers & total \\
\hline \multicolumn{6}{|l|}{ cropland expansion } \\
\hline population growth & 17 & 22 & 15 & 5 & 59 \\
\hline cotton cultivation & 5 & 1 & 1 & o & 7 \\
\hline other drivers & 7 & 2 & 2 & 2 & 13 \\
\hline \multicolumn{6}{|l|}{ pastureland decrease } \\
\hline clearing for cropping & 29 & 23 & 15 & 7 & 74 \\
\hline livestock increase & o & 3 & 1 & o & 4 \\
\hline other drivers & 1 & 3 & 2 & o & 6 \\
\hline \multicolumn{6}{|l|}{ reduction of watering points } \\
\hline cropping in the riverbanks & 19 & 14 & 12 & 4 & 49 \\
\hline precipitation decrease & 3 & 6 & 3 & 2 & 14 \\
\hline pond and streams siltation & 4 & 7 & 2 & o & 13 \\
\hline other drivers & 0 & 2 & o & o & 2 \\
\hline
\end{tabular}

\subsubsection{The competing claims for land among stakeholders}

Several competing claims for land were identified among the stakeholders. Narratives of the competing claims for lands in the three land segments (inWBR, buffer zone and outWBR) are summarized in Table 5. The most recurrent arguments to claim land were i) ownership due to expropriation in the past, ii) the unfair and/or incomplete implementation of the regulations in the WBR and the buffer zone, and iii) the shifting of pastoralist's mobile lifestyle. 
Pastoralists in a changing environment

Ownership of land due to past expropriation

The competing claims related to land expropriation in the past are between crop farmers and the WBR authorities and between crop farmers themselves. There were people settled in the current core of the WBR before its establishment as a National Park in 1954. Later, those people were displaced from inside the WBR, either by military force or with the purpose to shift state administration from dispersed homesteads into compact settlements close to main roads. This caused the resettlement of people in the current border of the WBR. Hence, nowadays, people claim ownership of land in the inWBR segment due to expropriation of ancestors' lands. In addition, some competing claims appear between the crop farmers who were already living in outWBR and the crop farmers that were resettled.

\section{Unfair and incomplete implementation of WBR's regulations}

The incomplete implementation of the regulations in the WBR and in the buffer zone is the argument of claims for land among crop farmers; between crop farmers and pastoralists; and between farmers and the authorities of the WBR.

In the study area, crop farmers living far away from the border of the WBR have been cultivating inside the WBR for relatively few years. Crop farmers living close to the WBR informed the WBR authorities to get them out, but no prosecution, enforcement or sanctions were taken. This was frustrating for the crop farmers living close to the WBR, even more so, because the land in the WBR once belonged to their ancestors and they feel that if someone has rights to these lands it should be them. In addition, in the South West part of the WBR (which is not part of the study area, but adjacent to it), thousands of hectares of lands are cultivated inside the Park (Houessou et al., 2013) with no reaction from Park officers. This situation, known to the inhabitants in the study area, has raised complaints and frustrations among the crop farmers and pastoralists. Now, they request land for cropping and grazing inside the WBR, as happens in this South West part.

The buffer zone was initially set to hold a cropping sub-zone, a grazing sub-zone, and a NTFP sub-zone (in consecutive parallel land segments from outWBR to inWBR) to be used by crop farmers, pastoralists and all inhabitants respectively. Each sub-zone was to be delimited to avoid encroaching use among these users. However, until now, these sub-zones have not been demarcated. As a consequence, cropland expanded 


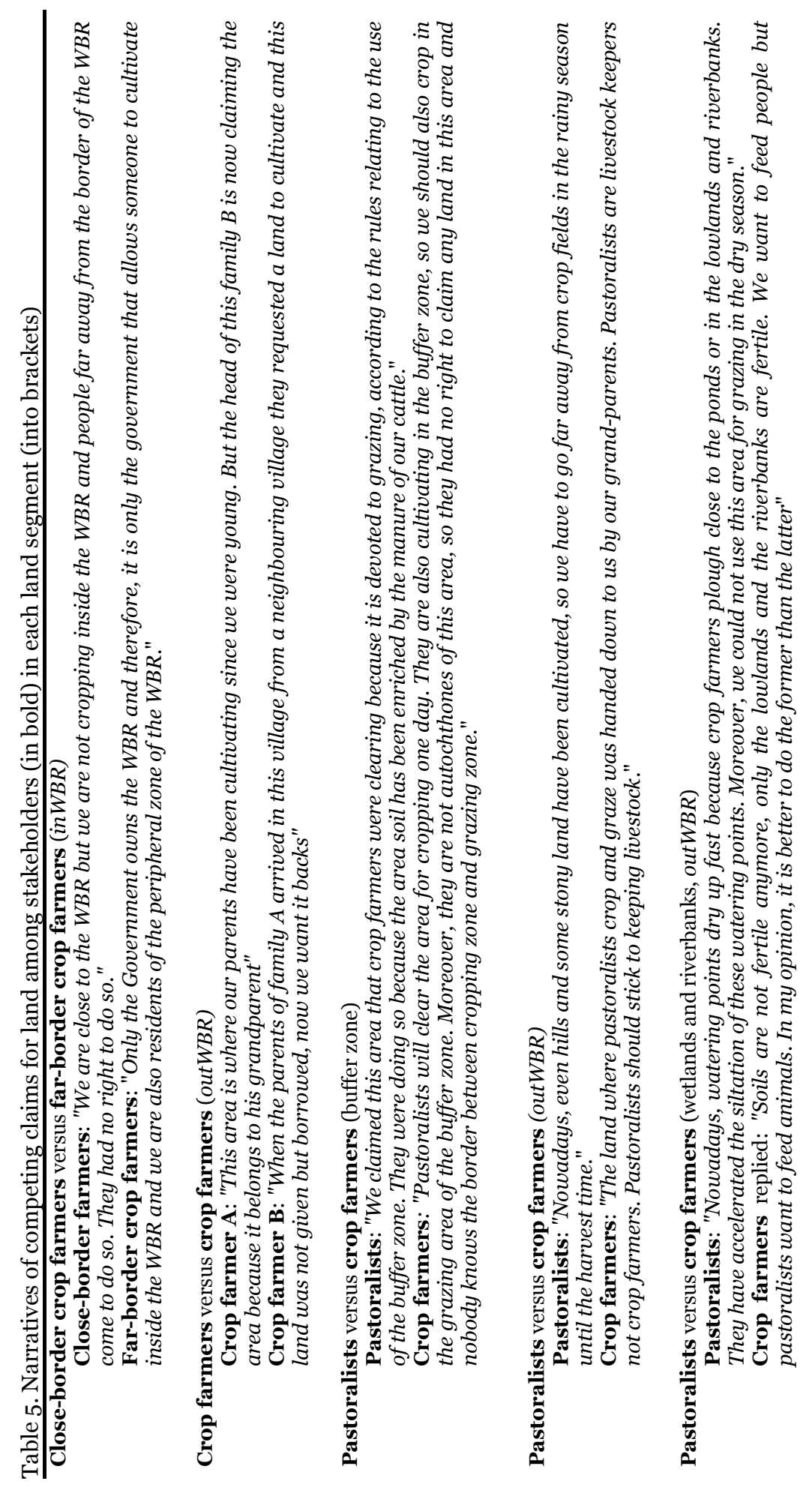




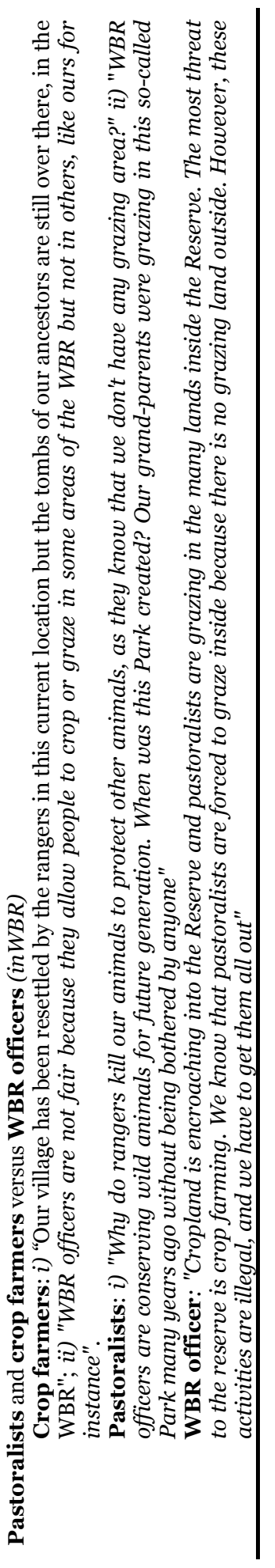


into the grazing sub-zone (trend also seen in Table 2), and conflicts caused by the competing land claims arose between crop farmers and pastoralists.

The shifting of pastoralist's mobile lifestyle

Historically, Fulbe pastoralists have been related to a mobile lifestyle searching for grazing resources for their herds. However, in response to land scarcity for grazing, they have turned to a sedentary lifestyle and started cropping on lands where their livestock were grazing previously. Crop farmers reacted by saying that pastoralists are allochthones and crop farmers are autochthones. Being autochthone involves a spiritual bond with the land, hence landownership and supremacy over the allochthones who were then denied to own land. Thus, the shifting of pastoralists' mobile lifestyle led to the competing claims for land between pastoralists and crop farmers.

\subsection{Discussion}

The data collected in this study show that the WBR authorities have been relatively successful in maintaining natural land cover inside the park, while outside the park cropland has expanded and the livestock number has decreased. Cropland expansion was identified as the direct driver of grazing lands' decrease, whereas regional population growth, associated with the demand for food and cash crops, and cotton cultivation were identified as indirect drivers. In response to cropland expansion, competing claims arose among stakeholders. Land was claimed as a mean for livelihood, and the main arguments supporting claims were: ownership of land because of past expropriation, unfair and incomplete implementation of the WBR regulations and shifting mobile lifestyle of pastoralists. In the following sections we discuss drivers of the expansion of cropland and arguments for the land claims.

\subsubsection{Drivers of the expansion of cropland}

\section{Population growth and the increasing demand for food crops}

It seems justified to conclude that the expansion of cropland is a consequence of the population growth in the region and the associated increased demand for food and use of land for cropping by pastoralists. Population growth in the region is explained by an increase of the local population by $4 \%$ annually during the last two decades (INSAE, 2013). People in North-Benin are generally rural, $81 \%$ on average (INSAE, 2004), and population growth has resulted in the settling of new farming 
Pastoralists in a changing environment

households. New farming households settled partly on inherited cropland, but also on new crop fields cleared on the land belonging to the parents. In addition to local consumption, crop expansion was also triggered by economic reasons: the selling of cash crops and food crops. The area dedicated to cultivation of food crops increased also in response to the increased demand for food by the urban regions in Benin and by the bordering countries, such as Nigeria and Niger. Benin is self-sufficient for maize, but there are regional differences: maize is a staple food in the south, whereas it is a cash crop in the north. The southern cities are supplied with maize by the northern regions (Lutz et al., 2006), which encompasses the study area. Regarding the bordering countries, Nigeria is the most populated country in Africa and, therefore, requires food to supply its people's needs; Niger is an arid country at risk of floods and droughts (Tarhule, 2005), which affects stability of crop production. Niger has to rely, therefore, on importation of food crops from Benin and other coastal countries (Blein and Soulé, 2013). In this regard, the city of Malanville, part of the study area, is a strategic market (Walther, 2009), since it borders Niger and Nigeria. Through this market, the area under study becomes an important food crop producer for Niger and Nigeria. Cropland expansion in response to population growth has been previously described in other studies, such as in Turner et al. (2011) for Niger, Burgoyne et al. (2015) for the Mkuze Game Reserve in South Africa, in Hartter et al. (2016) for Uganda and in Ningal et al. (2008) for Papua New Guinea. However, this is not always the case. Giannecchini et al. (2007) for South Africa and Reid et al. (2000) for Ethiopia, observed that increasing regional population did not result in cropland expansion, because of land scarcity and strict legislation concerning land use. In the area under study, land was apparently still available to be converted into cropland, under the present legislation and informal rules.

\section{Developments in the cotton sector}

Cotton accounts for nearly $40 \%$ of Gross Domestic Product and roughly $80 \%$ of the official export receipts, which sets cotton exports as vital to Benin's economy and an integral part of the country's development plans for poverty alleviation (Nicely, 2014). One third of Benin's population earns its income from the cotton sector (MAEP, 2011). Therefore, cotton is a strategic product and its cultivation has been promoted by all ruling governments since the 1980s. For example, government provides cotton farmers with free improved seed, and subsidised fertilisers and pesticides. Another government intervention has been the regulation of the cotton 
sector by establishing associations of producers along the chain e.g. village associations of cotton cultivators or associations of cotton manufacturers (Joachim, 2008). Recently, the government (in 2015) has facilitated finance through credit provision services of operating costs such as labour for cleaning fields and for harvesting cotton. Furthermore, some farmers reported that cotton is cultivated with the aim to have access to fertilisers, which are ultimately used for their food crop production (Maboudou A., 2014). All these incentives have made cotton cultivation attractive to crop farmers. This is very much aligned with our findings, which identify cotton as a major contributor to the cropland expansion. Cotton cultivation expansion as driver of land use change is consistent with the finding of Clerici et al. (2007) and Baudron et al. (2009) in Benin, of Ouedraogo et al. (2010) in Burkina Faso, and of Baudron et al. (2011) in Zimbabwe.

\subsubsection{Livelihood strategies in land use}

This study showed that the main source for competition is land, as was found in Turner et al. (2011) in Niger, not far from the area under study. Although pastoralists mentioned the decrease of watering points, watering was not considered as central issue. This may be due to the relative abundance of water, i.e. the Niger River and its tributaries Alibori, Mekrou and Sotat, in the study area.

Crop farmers are claiming land to sustain their families' needs in terms of food, but also to profit through the trade of food products and cotton. This cropland expansion was unfavourable for pastoralists as it occurred at the expense of grazing lands (i.e. savannah and forest) outside the WBR. According to the customary land rights, land belongs to the person who occupies it, and occupying means clearing the land usually for cropping (De Haan, 1997). Grazing does not imply ownership of the land. Hence, pastoralists' reaction has been a shift to settlement, and they have initiated cropping activities. Cropping by pastoralists is, therefore, used as a strategy to own land and secure their grazing area and their livelihoods. The mobile nature of Fulbe and the non-ownership of the land made them invisible land users. Facing shortage of land, the claims for lands devoted to grazing and the setup of cropping activities have made pastoralists become visible land users. The shifting of pastoralists from mobile lifestyle (invisible land users) into a rather settled lifestyle (visible land users) has drawn the attention of the "traditional" crop farmers and claims for land have arisen. Crop farmers state that pastoralists should stick to livestock production only, as 
Pastoralists in a changing environment

quoted by a crop farmer during individual interviews: "pastoralists are known as livestock farmers not crop farmers, they should keep on with that activity". Additionally, crop farmers argue that Fulbe pastoralists are allochthone in that region compared to crop farmers, who are the autochthone in the region (Benoit, 1999), implying that pastoralists cannot own land. Even though pastoralists are the last to be settled, it has been reported that pastoralists have been in the region since the $16^{\text {th }}$ to $17^{\text {th }}$ centuries (Benoit, 1999). The shifting of pastoralists' mobile lifestyle into crop farming is similar to that found in Ethiopia by Tsegaye et al. (2010), in Nigeria by Hoffmann (2004) in Niger by Turner et al. (2011) and by McCabe et al. (2010) in Tanzania. However, in Ethiopia, this shift was not a strategy to own land as it was in the area under study but it was considered as a strategy for coping with recurrent drought (Biazin and Sterk, 2013).

With regard to the use of land in the WBR, crop farmers and pastoralists are using the same strategy, i.e. they fight the unfair and incomplete regulations of the WBR and they claim the right on lands from which they were expropriated. Such arguments are similar to those reported for farmers in Uganda who were resettled to clear protected areas (Cavanagh and Benjaminsen, 2015). In their strategies to claim land in WBR, crop farmers and pastoralists did not have a united view. Indeed, during community meeting, one pastoralist quoted: "To be honest, if the rangers were not patrolling, the WBR would be entirely invaded by crop farming. In this case we pastoralists are lost”. This implies that pastoralists preferred the WBR to be under control of the WBR authorities than being invaded by crop farming. Indeed as reported by Butt (2011) in South Africa, protected areas are important for pastoralists' coping strategies.

\subsubsection{Implications for policy}

Pastoralists and their livestock are land users in the periphery of the WBR. Given the positive link between population growth and cropland expansion in the study area, and the ongoing population growth (INSAE, 2013), it is likely that the cropland expansion will continue in the outWBR, as long as there is still savannah and forest area to be converted. Government measures promoting food crops and cotton cultivation to boost the economic growth of the country will increase this conversion of savannah and forest currently used by livestock and by pastoralists. However, these policy interventions will continue to threaten pastoralists and their lifestyle. 
The reduction in grazing land, the constrained mobility of livestock, and the shift in pastoralists' lifestyle are likely to increase the competing claims between crop farmers and pastoralists in the outWBR. In the province comprising the study area, $87 \%$ of households depend on livestock for their livelihood (Nicely, 2014). Therefore options are needed for integrating crop production, pastoralism and their lifestyle, and nature conservation in the area.

Land scarcity in the outWBR is expected to increase pressure and conflicts in the buffer zone of the WBR first. In fact, as seen in this study, the poor implementation of regulations in the buffer zone and the lack of support to pastoralists has triggered the expansion of arable land (66\% of the land) at the expense of grazing lands. After the buffer zone, the pressure inside the WBR may follow. This might increase tensions between crop farmers and pastoralists, and eventually, conflicts between them and the authorities of the WBR. Constrained mobility of pastoralists, weak implementation of regulations and inappropriate integration of pastoralists in the policy agendas have been identified as source of conflicts (De Haan et al., 2016) . According to Garcia et al. (2016), customary means of governance are barely recognized by governmental institutions, and pastoralists face the threat of reduced mobility and impoverishment, as sedentary life leads to reduced opportunities and increased costs. As seen in this study, weak implementation of the regulations by the authorities of the WBR, especially in the buffer zone, frustrated inhabitants in the region and fuelled the competing claims, and eventually tensions and conflicts.

Conservation depends on the attitude (Agrawal and Redford, 2009) of the people living close to the WBR. Population growth, and the associated competing claims for land are important threats for the integrity of the WBR. As stated in Reid et al. (2004), we need to better understand African pastoral systems: the causes of loss and fragmentation of pastoral lands; and the consequences for people and their livelihoods (Davies et al., 2016), their livestock and wildlife.

\subsection{Conclusion}

This study addressed the dynamics in land use and land use change inside and in the bordering area of the WBR and analysed the drivers behind this land use change. In addition, the competing claims for land among stakeholders (i.e. pastoralists, crop farmers and WBR authorities) were identified. In general, the WBR has been 
Pastoralists in a changing environment

successful in maintaining natural land cover; cropland has expanded outside the WBR; and presence of livestock has decreased. Cropland expansion was the direct driver of decrease of grazing land. Indirect drivers of the decrease of grazing land were population growth and the associated increases in demands for food crop products (at a regional and international level) and for cash crops, i.e. governmental policies to stimulate cotton cultivation. Cropland expansion by crop farmers, and sedentarisation of pastoralists, has triggered competing claims for land among stakeholders; namely between crop farmers and pastoralists, among crop farmers themselves, and between crop farmers and pastoralists and the WBR authorities. The main arguments put forward for land ownership were: right to land because of past expropriation, the unfair and incomplete implementation of the regulations of the WBR and the shifting of the mobile lifestyle of pastoralists into settled crop farmers. This study suggests that pastoralism is under so much threat that its survival depends on policies to protect grazing lands for herding.

\section{Acknowledgements}

The research project from which this paper draws was funded by Netherlands organisation for international cooperation in higher education (NUFFIC) of the Netherlands and the Animal Production Systems group of Wageningen University \& Research. The authors thank Frank de Haan, Guiriguissou A. Maboudou and Rachid Saliou Toure for useful discussion, as well as two anonymous reviewers for their invaluable comments on earlier version of this manuscript. We are also grateful to Laura Webb for editing the English of the manuscript. 


\section{Chapter 3}

Effect of grazing on aboveground vegetation and soil seed banks in the W Biosphere Reserve, Benin Republic

Tamou C, Ripoll Bosch R, de Boer IJM, Oosting SJ

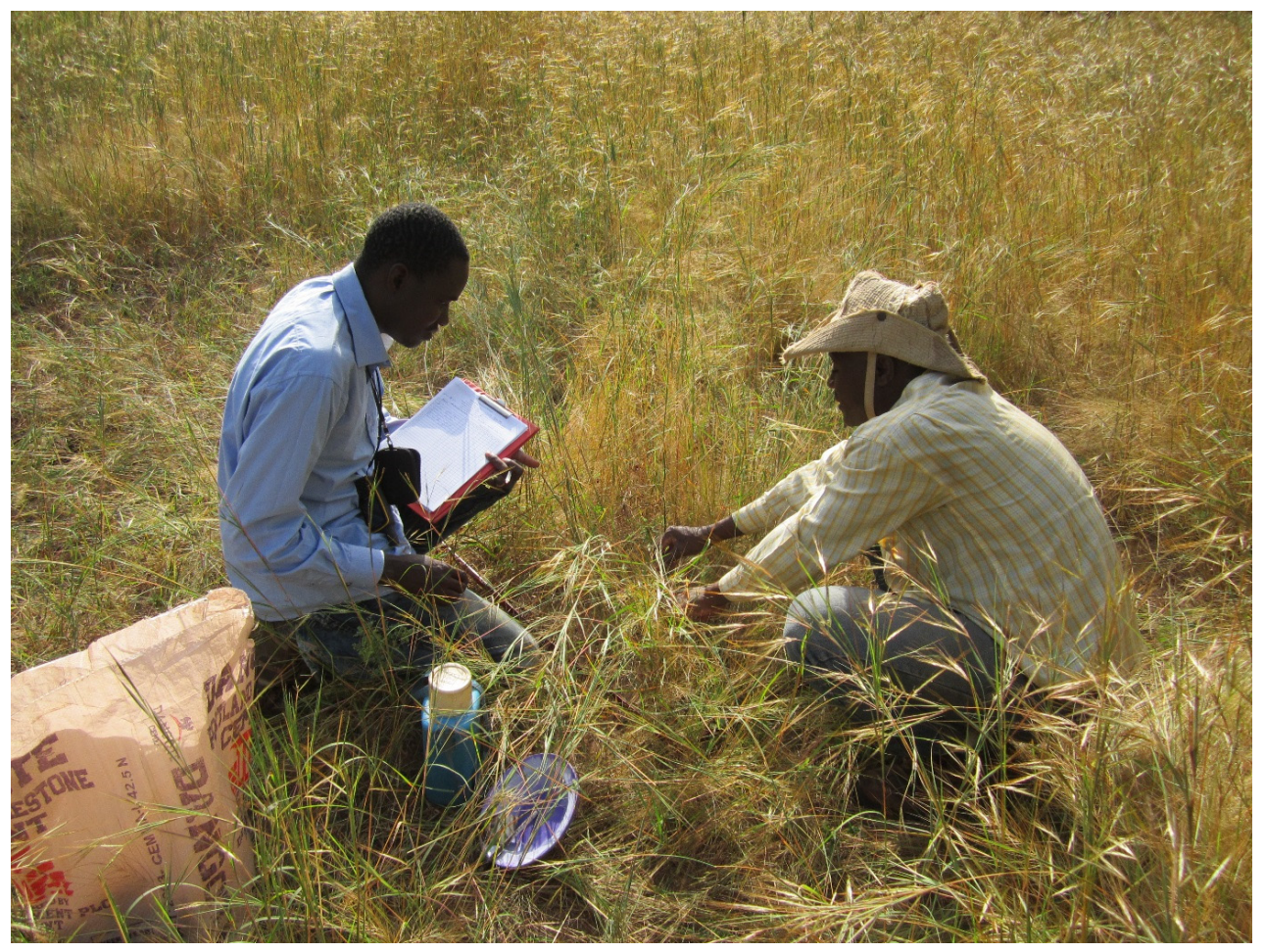

Plant inventory inside the WBR 


\section{Abstract}

The W Biosphere Reserve (WBR) in Benin has been subject to grazing by pastoralists for many years. So far, however, the effect of grazing and its intensity on the plant community diversity in WBR is unknown. We assessed, therefore, the effect of low (L) and high $(\mathrm{H})$ grazing intensities on plant abundance and species richness, in aboveground vegetation and in soil seed banks. We addressed the following objectives i) to assess the effect of grazing intensity on plant abundance and species richness in the aboveground vegetation; ii) to assess the effect of grazing intensity on seed abundance and species richness in the soil seed bank; iii) to assess the effect of grazing intensity on similarity of species prevalence between aboveground vegetation and soil seed bank. We performed a plant inventory for the aboveground vegetation for $\mathrm{L}$ and $\mathrm{H}$ in 8 sampling sites. A pot experiment with a randomized block design was used to study seed germination of the upper and deeper soil layers of soil seed banks collected at the same sites. In aboveground vegetation, grazing increased overall species richness and that of forbs. In soil seed banks, grazing increased overall plant abundance, abundance of forbs and legumes, and species richness of forbs and legumes only. More plants and more species emerged from the upper than from the deeper soil layers. Annual species dominated aboveground vegetation and soil seed banks. A high dissimilarity was detected between species prevalence in aboveground vegetation and soil seed banks. Our results suggest that the current levels of grazing increase species diversity in WBR and that restoration of grasslands with more perennials may require human intervention.

Key-words: species richness, plant abundance, functional group, soil seed banks, grassland 
Effect of grazing on aboveground vegetation and soil seed banks

\subsection{Introduction}

Composition of plant communities in grassland and rangeland ecosystems (further referred to as grasslands) determines ecosystems' functioning and services, such as provision of food, fodder, materials, biodiversity and a habitat for living (Briske et al., 2005; Cardinale et al., 2012). Besides climate and fire, grazing is a primary factor determining dynamics and composition of plant communities in grasslands (Koerner and Collins, 2014). Understanding the relationship between composition of plant communities and grazing intensity, therefore, is important for sustainable management of grasslands (Connell, 1978; Milchunas et al., 1988).

Plant communities are defined as collections of plant species growing together in a particular location that show a definite association or affinity with each other (Kent, 2012). Species richness (the number of species per unit area), and plant abundance (the number of plants per unit area) are related to plant community productivity (Proulx and Mazumder, 1998). Dìaz and Cabido (2001) showed a positive relation between plant species richness and ecosystem processes in aboveground primary production. Another study showed that besides species diversity, functional groups play a critical role in the dynamics and the functioning of ecosystems (Tilman, 2001). To understanding the functioning of plant communities in grasslands, therefore, we need to jointly monitor species diversity, plant abundance and functional groups.

In the aboveground vegetation, the intermediate disturbance hypothesis (IDH) (Connell, 1978), describes the effect of disturbance (e.g. grazing) on species diversity in grasslands. IDH suggests that, in a gradient of increasing disturbance intensity, species diversity will first increase to reach a peak of diversity at an intermediate level of the disturbance and will decrease at further increase of that disturbance. Under low grazing intensity, tall species may outcompete short ones because of their superior ability to capture light (Landsberg et al., 2002). Moreover, high standing biomass under low grazing intensity may fuel unavoidable bushfires, which may alter species composition and soil fertility (Tilman and Lehman, 2001), as well as the size and composition of the soil seed banks (Snyman and van Wyk, 2005). Under intermediate grazing intensity, competition for light is reduced (Milchunas et al., 1988), and fuel load is reduced, which reduces the impact of bushfires on species diversity (Van Langevelde et al., 2003). A high grazing intensity may deplete the soil seed bank and prevent tillering, causing reduction of species diversity (Tessema et 
al., 2012), which is often referred to as overgrazing. Milchunas et al. (1988) extended the IDH by including the effect of gradients of precipitation and evolutionary history of grazing on plant communities. Based on the extended IDH, they argued that grasslands in relatively dry climatic conditions that are adapted to grazing, such as the Sahel, are affected by grazing only to a minor extent, while grasslands in relatively humid climates, such as coastal humid areas in West Africa, which are not adapted to grazing, may be affected severely.

The composition of the aboveground vegetation is furthermore influenced by seed abundance and species diversity in the soil seed bank (Thompson and Withers, 2003). The soil seed bank is defined as "a reserve of viable seeds present in the soil and on its surface" (Roberts, 1981). The seed bank in the soil can, therefore, facilitate the recovery of species that disappeared from heavily grazed aboveground vegetation. Information of soil seed bank potential to recover aboveground vegetation is measured by the species similarity between soil seed bank and that aboveground vegetation (Hopfensperger, 2007). Studies of effects of grazing on species diversity and plant abundance in soil seed banks show disparate results. A high grazing intensity may decrease (Tessema et al., 2012) or increase species diversity in soil seed banks (Dreber and Esler, 2011) or have no effect (Meissner and Facelli, 1999). A high grazing intensity may decrease (Tessema et al., 2012) or increase seed abundance (Dreber and Esler, 2011) in the soil seed banks. Moreover, in Sub-Sahara African rangelands, studies to elucidate the role of soil seed banks in the restoration of the grazing-degraded vegetation are scant (Dreber and Esler, 2011; Hopfensperger, 2007).

Pastoralism, which is defined as a livestock production system characterised by movement of herds, either constantly or seasonally between territories, mainly uses communal grazing lands (Ayantunde et al., 2011). Pastoralism, therefore, is often perceived as an important threat for overgrazing of communal grazing lands, in line with Garret Hardin's theory of the "Tragedy of the commons" (Hardin, 1968). As a policy to reduce the risk of overgrazing, governments i.a. try to privatise grasslands and to sedentarise pastoralists. It is questioned, however, whether pastoralism is to be blamed for overgrazing and grassland deterioration, and whether land privatisation and sedentarisation result in improved grassland ecosystem quality (Ayantunde et al., 2011; Fratkin and Mearns, 2003). To improve grazing 
Effect of grazing on aboveground vegetation and soil seed banks

management, therefore, we need detailed insight into the effect of grazing at a specific location.

The W Biosphere Reserve (WBR) in Benin has been subject to grazing by resident and transhumant pastoralists for many years (Tamou et al., 2015). So far, however, the effect of grazing and its intensity on the plant community diversity in the WBR is unknown. Our aim, therefore, was to evaluate whether the present grazing regime in the border of and inside the WBR affects plant community diversity by addressing the following objectives i) to assess the effect of grazing intensity on plant community diversity in the aboveground vegetation; ii) to assess the effect of grazing intensity on seed abundance and species diversity in the soil seed bank; iii) to assess the effect of grazing intensity on similarity of species prevalence between aboveground vegetation and soil seed bank. The present study contributes to design of better management practices for the conservation areas of sub-Saharan Africa, and specifically the WBR in Benin.

\subsection{Material and methods}

\subsubsection{Study area}

This study was carried out in the WBR (former National Park of W) in North Benin. The WBR ( $11^{\circ} 26^{\prime}$ to $12^{\circ} 26^{\prime} \mathrm{N}$ and $2^{\circ} 17^{\prime}$ to $3^{\circ}$ o5' E) comprises about $56 \%$ of the W Transboundary Biosphere Reserve located in the countries of Benin, Niger and Burkina Faso, and covers about $5632 \mathrm{~km}^{2}$. The vegetation of the WBR consists of tree, shrub and woodland savannah, gallery forest and wetland. This vegetation allows the presence of several wildlife species, such as elephants, lions, buffaloes, cheetahs, waterbucks, monkeys, and birds. The regional water supply comes from the Niger River and its tributaries: the Alibori, Mekrou and Sota watercourses. The climate of the WBR is characterised by two main seasons: a rainy season from mid-May to October, with an average minimum daily temperature of $12{ }^{\circ} \mathrm{C}$, an average maximum daily temperature of $25^{\circ} \mathrm{C}$, and precipitation ranging from 700 to $1000 \mathrm{~mm}$, and a dry season from November to mid-May, with an average minimum daily temperature of $30{ }^{\circ} \mathrm{C}$, an average maximum daily temperature of $40^{\circ} \mathrm{C}$ and hardly any precipitation (Billand et al., 2005). During the first part of the dry season, from November to February, a dry dusty wind blows through the North of Benin, also referred to as harmattan, which boosts the drying process of natural pasture. The harmattan 
facilitates burning of dried pasture, either from prescribed (early fire) used to reduce fuel accumulation or from late bush fire. Most grasslands experience fire every year.

The WBR is surrounded by several villages. Between the park and the lands cultivated by the villages, we find a so-called buffer zone, which is a land segment of $5 \mathrm{~km}$ width set by WBR authorities. This buffer zone is used by residents under certain conditions, such as payment of fees for crop farming, grazing, or harvesting of nontimber forest products and strict use for what it was allowed for. Expansion of crop farming outside the WBR, on the one hand, and the availability of pasture inside the WBR, on the other hand, have increased the illegal use of the WBR by resident and transhumant pastoralists putting the natural vegetation under pressure (Tamou et al., 2015).

\subsubsection{Study design and data collection}

\subsubsection{Sampling sites}

We selected eight locations alongside the WBR border, along a $100 \mathrm{~km}$ range from the South to the North. Average rainfall ranged from $1004 \mathrm{~mm} /$ year in the South, to $781 \mathrm{~mm} /$ year in the North, based on data (1997-2015) from the Centre d'Action Régionale pour le Développement Rural (CARDER) of Borgou-Alibori. In each location, we selected 2 sampling sites with contrasting grazing intensity management: high grazing intensity $(\mathrm{H} ; \mathrm{n}=8)$ and low grazing intensity $(\mathrm{L} ; \mathrm{n}=8)$. Sampling sites were defined as areas of 1 ha with homogeneous vegetation. We selected the two grazing intensities on basis of direct observations of the height of herbaceous vegetation. Our categorization of $\mathrm{L}$ and $\mathrm{H}$ was confirmed by the WBR authorities. Sites under $\mathrm{H}$ were sites with short herbaceous vegetation $(<0.5 \mathrm{~m}$ of height), while sites under $\mathrm{L}$ were sites with tall herbaceous vegetation ( $>1 \mathrm{~m}$ of height). Likewise, sampling sites under $H$ were at the edge of the WBR or in its buffer zone, and sites under L were inside the WBR. Coordinates of each sampling site were recorded with a Geographical Positioning System (GPS). The bush fire history of $\mathrm{H}$ and L sites were similar, i.e. annual burning occurred.

\subsubsection{Species inventory and biomass harvesting of aboveground vegetation}

To study the aboveground vegetation we recorded the botanical species and quantified the standing biomass by total harvesting from 20 quadrats (each quadrat being a 
Effect of grazing on aboveground vegetation and soil seed banks

frame of $1 \mathrm{~m}^{2}$ ), randomly selected within each sampling site of 1 ha. We conducted a species inventory when grass species were flowering in October 2013, to facilitate botanical identification. We recorded the botanical name and number of individuals for each species within each quadrat. Biomass harvesting took place at the peak of biomass production in October 2014. Exactly the same sites were visited in 2013 and 2014. Since the average rainfall in the study area for 2013 and 2014 were almost similar, $850 \mathrm{~mm}$ and $883 \mathrm{~mm}$, respectively (adapted from data of CARDER BorgouAlibori), biomass quantities and species diversity for these two years were expected to be similar. Visual observation confirmed the similarity between the standing biomass for the two years. Herbaceous plants were cut up to $1 \mathrm{~cm}$ (aboveground) using pruning shears; litter was discarded and the plants were sorted into functional groups of species. Functional groups are sets of species which have similar response to the environment and similar effects on ecosystem functioning (Dìaz and Cabido, 2001). The term functional group is used as a vegetation unit in ecological studies for investigating ecosystem processes and it is considered an appropriate vegetation unit in assessing pasture conditions (Boer and Stafford Smith, 2003).

We identified the following functional groups (between brackets: names of botanical families to which the functional groups belong): grasses (Poaceae), legumes (Fabaceae), forbs (many families e.g. Euphorbiaceae, Araceae and Rubiaceae), grasslikes (Cyperaceae) and ligneous species (e.g. Combretaceae and Sapotaceae). Biomass from each functional group was stored in a paper bag, sun-dried for one week until mass remained constant, and sample dry matter mass was recorded. For this study, the following parameters were assessed: plant abundance (number of plants (total and per functional group) per unit of area), species richness (number of species (total and per functional group) per unit area) and biomass (total and per functional group; forbs, grass-likes and ligneous species combined).

\subsubsection{Sampling soil seed bank}

In October 2013, we collected soil samples in the same sampling sites as for aboveground vegetation to study the soil seed bank (Tessema et al., 2012). In October, seeds persisting from the previous growing seasons can still germinate and seed dispersal for the current growing season is at its peak (Savadogo et al., 2016), hence samples contained both transient and persistent seeds. 
At the core of each quadrat, we collected the soil inside an area of $15 \mathrm{~cm} \mathrm{x} 15 \mathrm{~cm}$ at two different depths: the upper soil layer, depth from o to $5 \mathrm{~cm}$ (henceforth UL), and the deep soil layer, depth from 5 to $10 \mathrm{~cm}$ (henceforth DL). We used one third of the soil volume sampled at UL and DL for further analysis. For each sampling site and soil depth, we pooled samples from all quadrats, implying we finally analysed 32 soil samples (8 locations; 2 grazing intensities; 2 soil depths). All roots and other debris were removed from these soil samples, by manually breaking soil clods and removing debris and roots. Samples were stored in cloth bags under dry conditions.

\subsubsection{Germination of seed from soil seed bank}

The pot experiment to study germination of the soil seed bank samples was set up in the greenhouse of the University of Parakou ( $9^{\circ} 20^{\prime} 60 \mathrm{~N}$ and $2^{\circ} 37^{\prime} \mathrm{o}$ E) in Benin Republic. This greenhouse consisted of a frame covered with a net to allow air, light and rain water passing through, but to avoid predation and contamination by external seeds. To avoid site-specific characteristics of the greenhouse that might influence the distribution of light over the experiment, we used a randomized block design with 4 replications for each of the 32 samples of soil seed bank, yielding a total of 128 observations. Each of the 128 plastic pots (0.051 $\mathrm{m}^{2}$ and $20 \mathrm{~cm}$ of height) was filled with sterilised sand ( 45 to 60 minutes at 100 degrees centigrade) up to $15 \mathrm{~cm}$ height. We spread $3 \mathrm{~cm}$ of soil seed bank sample on top of the sterilised sand. We added 2 control pots to each replication, which were pots filled with the sterilised sand only. Pots were set on pallets inside the greenhouse to avoid contact with soil. All the pots were watered every 2 days during the dry season and if necessary during the rainy season. No artificial light was supplied for the experiment. Pots were examined weekly during 11 months (from December $2^{\text {nd }}, 2013$ till October 30 $0^{\text {th }}, 2014$ ). When identifiable, we recorded botanical name of plant species which emerged and the number of individuals per species. Identified species were removed from pots.

We identified plant abundance (number of plants (total and per functional group) per pot), and species richness (number of species (total and per functional group) per pot). Plant abundance was used as a measure for the number of viable seeds in the soil seed bank and species richness as a measure for the composition of species in the soil seed bank (Roberts, 1981). Equally to the aboveground vegetation, we sorted out the species that emerged from the soil seed banks into functional groups: grasses, legumes, forbs, grass-likes and ligneous species. 
Effect of grazing on aboveground vegetation and soil seed banks

\subsubsection{Statistical analysis}

For the aboveground vegetation data, we tested for difference in standing biomass between $\mathrm{H}$ and $\mathrm{L}$ sites. As variances were not homogeneous for $\mathrm{H}$ and $\mathrm{L}$, we used a Welch t-test to compare means.

Relations within each grazing intensity, between latitude of sampling site on the one hand, and on the other hand aboveground biomass, plant abundance and species richness were tested by Pearson's correlations.

To test for the effect of grazing intensity on plant abundance and species richness (total and between functional groups) for aboveground vegetation, we used a generalised linear mixed-effects models (GLMMs). GLMMs can account for nonnormality of the residuals for the dependent variable with a relative higher number of observations being zero, and for dependence of observation between UL and DL. Grazing intensity was incorporated in the statistical model as a fixed effect and sampling site as a random effect. As the dependent variables were count data, we first used a Poisson error distribution and checked for overdispersion using the ratio deviance/degree of freedom of the residuals (Zuur et al., 2009). To handle overdispersion, we used a negative binomial error structure with a log-link function (natural logarithm) in R 3.2.3 using the "glmmADMB" package. The model was:

$Y_{i}=g\left(B_{o}+B_{1} X_{i}+r\right)+\varepsilon$

where $Y_{i}$ is either plant abundance or species richness, $B_{o}$ is the model intercept, $X_{i}$ is the grazing intensity (fixed effect), $B_{1}$ measures the effect of grazing intensity i.e. $\ln (\mathrm{L} / \mathrm{H}), r$ is the random sampling site effect , $\varepsilon$ the error term and $g$ is the log-link function.

To test the grazing intensity effect and soil depth effect in the soil seed bank on plant abundance and species richness, we used GLMMs following the same procedure as described above for aboveground plant abundance and species richness. Grazing intensity and soil depth were incorporated in the models as fixed effects (without their interaction because it was not significant), and sampling site and replicate were included as random effects. The model was:

$Y_{i}=g\left(B_{o}+B_{1} X_{i}+B_{2} Z_{i}+r\right)+\varepsilon$ 
where $Y$ is either plant abundance or species richness, $B_{o}$ the intercept and $X_{i}$ grazing intensity, $B_{1}$ measures the effect of grazing intensity i.e. $\ln (\mathrm{L} / \mathrm{H}), Z_{i}$ soil depth (fixed effect), $B_{2}$ the effect of soil depth i.e. $\ln (\mathrm{UL} / \mathrm{DL}), r$ the random effects of sampling site and replicate, $\varepsilon$ the error term and $g$ is the log-link function.

Statistical inference was based on the significance of regression coefficients which represents the effects of independent variables. Coefficients were the ratio $\mathrm{L} / \mathrm{H}$ (for the grazing intensity effect) and UL/DL (for the soil depth effect). Because of the specified log-link function, model estimates of the grazing intensity effect and of the soil depth effect and their confidence intervals were natural log values which, for presentation, were exponentially transformed.

To estimate dissimilarity in species composition between soil seed bank and aboveground vegetation under different grazing intensity, we used the Jaccard's dissimilarity index (Gotelli and Ellison, 2013) based on presence-absence data. The Jaccard's dissimilarity index ranges from o (two sampling sites share 100\% of species) to 1 (two sites sampling do not share any species).

Effects and differences are only explicitly mentioned in the results section if significant ( $p$ < 0.05), unless otherwise mentioned. Means are presented with their standard deviation and expressed as mean \pm standard deviation.

\subsection{Results}

\subsubsection{Grazing intensity and the standing aboveground biomass}

The total aboveground biomass was higher in L-sites $\left.(418.7 \pm 100.92) \mathrm{g} / \mathrm{m}^{2}\right)$ than in $\mathrm{H}$-sites $\left(182.7 \pm 63.69 \mathrm{~g} / \mathrm{m}^{2}\right)$. Biomass from grasses was higher in L (329.1 \pm 40.69$)$ $\left.\mathrm{g} / \mathrm{m}^{2}\right)$ than in $\mathrm{H}$ sites $\left.(71.5 \pm 13.83) \mathrm{g} / \mathrm{m}^{2}\right)$. In contrast, biomass from legumes was lower in $\mathrm{L}\left(41.8 \pm 8.58 \mathrm{~g} / \mathrm{m}^{2}\right)$ than in $\mathrm{H}\left(72.9 \pm 11.58 \mathrm{~g} / \mathrm{m}^{2}\right)$ sites. Forbs, grass-likes and ligneous species were combined into "other species" and they did not differ between L-sites $\left(47.7 \pm 12.04 \mathrm{~g} / \mathrm{m}^{2}\right)$ and H-sites $\left(38.4 \pm 6.37 \mathrm{~g} / \mathrm{m}^{2}\right)$.

\subsubsection{Effects of grazing on plant abundance and species richness in the overall aboveground vegetation}

We found 54007 individual plants belonging to 219 species and to 41 families in the aboveground vegetation (Supplementary material A). The most abundant species were Spermacoce radiata (15\%), Tephrosia pedicellata (12\%) and Microchloa indica 
Effect of grazing on aboveground vegetation and soil seed banks

(10\%). The most abundant families were Poaceae (49\% of the total), Rubiaceae (22\% of the total) and Fabaceae (19\% of the total). Grazing intensity had no effect on plant abundance, whereas species richness was lower at L-sites (45.1 \pm 10.95 species/ha) than at H-sites $(54.7 \pm 9.51$ species/ha) (Table 1$)$.

Table 1. Effects of grazing intensity on plant abundance and species richness

\begin{tabular}{llll}
\hline response variable & coefficient ${ }^{1}$ & $\begin{array}{l}95 \% \text { confidence } \\
\text { interval }\end{array}$ & significance \\
\hline plant abundance (plants $\left./ \mathrm{m}^{2}\right)$ & 1.03 & {$[0.77,1.39]$} & 0.820 \\
species richness $\left(\right.$ species $\left./ \mathrm{m}^{2}\right)$ & 0.82 & {$[0.69,0.97]$} & 0.021 \\
\hline $\begin{array}{l}{ }^{1} \text { coefficient is L/G for the response variable (L=low grazing intensity and } \mathrm{H}=\text { high } \\
\text { grazing intensity) }\end{array}$
\end{tabular}

\subsubsection{Effects of grazing on functional groups in the aboveground vegetation}

Of the total 54007 individuals, $49 \%$ were grasses, $31 \%$ forbs, $19 \%$ legumes and $1 \%$ grass-like and ligneous species. We also found that 54 of the 219 total species were grasses, 89 forbs, 42 legumes, 9 grass-likes and 25 ligneous species. Grazing intensity had no effect on plant abundance within functional groups, and it increased species richness within forbs only, i.e. 15.7 \pm 4.67 at L-sites and 19.6 \pm 2.97 species/ha at Hsites (Figure 1 and Table 2). Within the grasses, annuals were the most abundant (91.8 \% of total for H-sites and $90.5 \%$ for L-sites) and they contributed most to species richness (78.6\% of the total for H-sites and $76.6 \%$ L-sites).
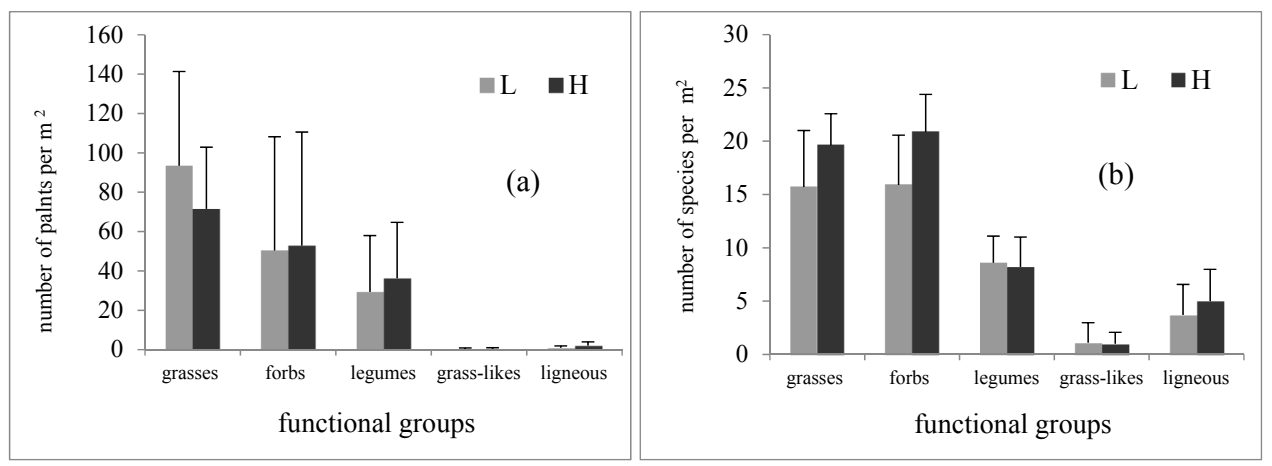

Figure 1. Effect of grazing intensity on plant abundance (a) and species richness (b) within functional groups in the aboveground vegetation ( $\mathrm{L}=$ low grazing intensity and $\mathrm{H}=$ high grazing intensity; bar indicates mean; error bar indicates sd) 
Table 2. Effects of grazing intensity on plant abundance and species richness within functional groups in the aboveground vegetation

\begin{tabular}{llll}
\hline response variable & coefficient ${ }^{1}$ & $\begin{array}{l}\text { 95\% confidence } \\
\text { interval }\end{array}$ & significance \\
\hline plant abundance (plants $\left./ \mathrm{m}^{2}\right)$ & & & \\
$\quad$ grasses & 1.31 & {$[0.86,1.99]$} & 0.210 \\
$\quad$ forbs & 0.82 & {$[0.54,1.23]$} & 0.330 \\
legumes & 0.65 & {$[0.28,1.49]$} & 0.310 \\
grass-likes & 0.76 & {$[0.09,6.19]$} & 0.802 \\
ligneous species & 0.45 & {$[0.15,1.32]$} & 0.150 \\
species richness (species $\left./ \mathrm{m}^{2}\right)$ & & & \\
grasses & 0.93 & {$[0.40,2.15]$} & 0.870 \\
forbs & 0.76 & {$[0.60,0.95]$} & 0.017 \\
legumes & 1.02 & {$[0.76,1.36]$} & 0.900 \\
grass-likes & 0.89 & {$[0.27,4.48]$} & 0.875 \\
ligneous species & 0.68 & {$[0.29,1.59]$} & 0.370 \\
\hline
\end{tabular}

${ }^{1}$ coefficient is $\mathrm{L} / \mathrm{H}$ for the response variable (L=low grazing intensity and $\mathrm{H}=$ high grazing intensity)

\subsubsection{Effect of latitude on aboveground vegetation}

Total biomass $(\mathrm{r}=-0.87, \mathrm{p}=0.005)$ and biomass of grasses $(\mathrm{r}=-0.91, \mathrm{p}=0.002)$ decreased from lower to higher latitude (south to north; from higher to lower precipitation), in L-sites. However, latitude was not correlated with biomass of the other functional groups in the L-sites and of all functional groups in the $\mathrm{H}$-sites.

Plant abundance was not correlated with latitude within functional groups in the Lsites and in the $\mathrm{H}$-sites, except for forbs whose plant abundance tended to increase ( $\mathrm{r}=0.69, \mathrm{p}=0.06$ ) with latitude.

Species richness was not correlated with latitude within functional groups in the Lsites. However, the overall species richness increased from lower to higher latitude $(\mathrm{r}=\mathrm{0.88}, \mathrm{p}=0.004)$ in the $\mathrm{H}$-sites.

\subsubsection{Effects of grazing intensity and soil depth on overall plant abundance and overall species richness in soil seed banks}

Overall, 1601 plants belonging to 115 species and to 26 families emerged from the soil seed banks (Supplementary material A). Euphorbia hirsuta was the most abundant species with $28 \%$ of total plant abundance. The most abundant families were Poaceae (31\% of the total), Euphorbiaceae (28\% of the total) and Cyperaceae (14\% of the total). 
Effect of grazing on aboveground vegetation and soil seed banks

Plant abundance of seed emerging from soil seed banks was higher for H-sites than for L-sites, and higher for UL than for DL. Species richness of plants emerging from soil seed banks (hereafter referred to as species richness in soil seed banks) was also higher for UL than for DL, but not affected by the grazing intensity (Figure 2, Table 3).

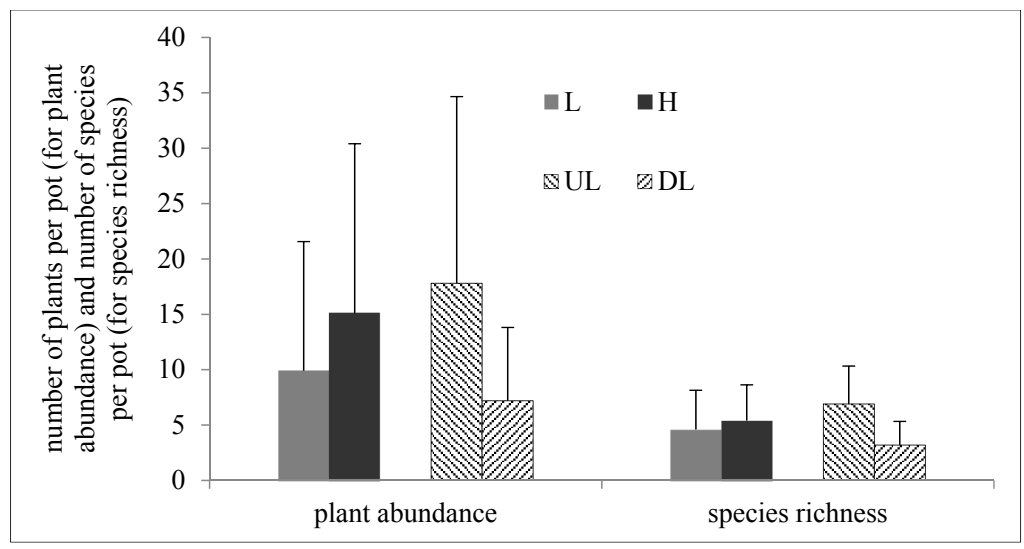

Figure 2. Effect of grazing intensity and soil depth on overall plant abundance and species richness in the soil seed banks ( $\mathrm{L}=$ low grazing intensity and $\mathrm{H}=$ high grazing intensity; $\mathrm{UL}=$ upper soil layer and DL=deeper soil layer; bar indicates mean; error bar indicates sd)

Table 3. Effects of grazing intensity and soil depth on overall plant abundance and overall species richness in the soil seed banks

\begin{tabular}{llll}
\hline variables & coefficient $^{1}$ & $\begin{array}{l}95 \% \text { confidence } \\
\text { interval }\end{array}$ & significance \\
\hline $\begin{array}{l}\text { grazing intensity } \\
\text { overall abundance }\left(\text { plants } / \mathrm{m}^{2}\right)\end{array}$ & 0.60 & {$[0.47,0.77]$} & $<0.001$ \\
$\begin{array}{l}\text { overall species richness }\left(\mathrm{species} / \mathrm{m}^{2}\right) \\
\text { soil depth }\end{array}$ & 0.84 & {$[0.70,1.00]$} & 0.055 \\
$\quad \begin{array}{l}\text { overall abundance }\left(\text { plants } / \mathrm{m}^{2}\right) \\
\text { overall species richness }\left(\mathrm{species} / \mathrm{m}^{2}\right)\end{array}$ & 2.17 & {$[1.92,3.11]$} & $<0.001$ \\
\hline
\end{tabular}

${ }^{1}$ coefficient for the response variable is $\mathrm{L} / \mathrm{H}$ for grazing intensity and UL/DL for soil depth (L=low grazing intensity and $\mathrm{H}=$ high grazing intensity; $\mathrm{UL}=$ upper soil layer and $\mathrm{DL}=$ deeper soil layer)

\subsubsection{Effects of grazing and soil depth on functional groups in the soil seed banks}

From the total of 1601 individual plants that germinated from the soil seed banks, $31 \%$ were grasses, $47 \%$ forbs, $6 \%$ legumes, $14 \%$ grass-likes, and $1 \%$ ligneous species. From the total of 115 species which emerged from the soil seed banks, 38 were grasses, 43 forbs, 14 legumes, 15 grasses-likes and 5 ligneous species. Plant abundance within forbs and legumes differed between grazing intensities in the soil 


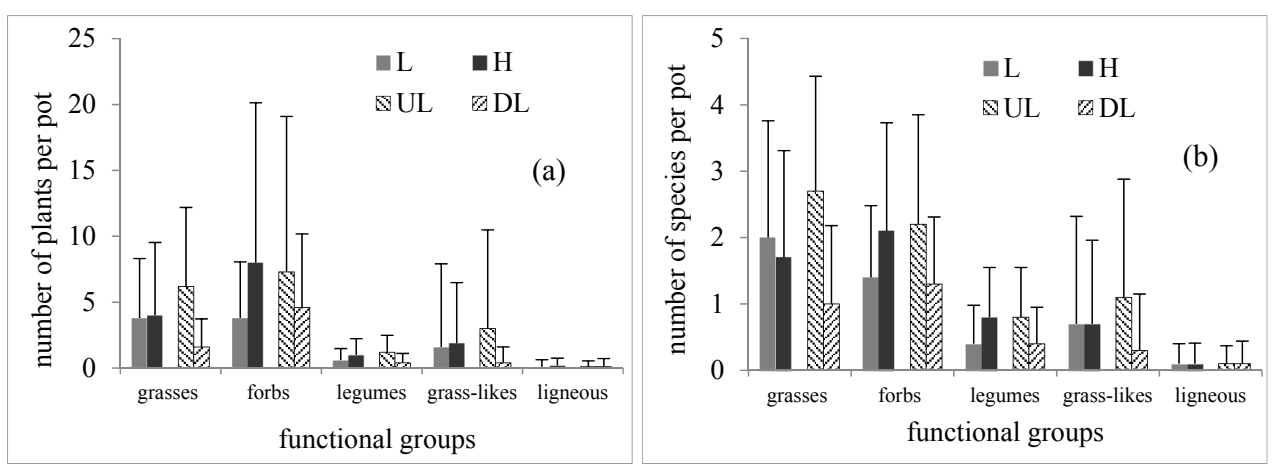

Figure 3. Effect of grazing intensity and soil depth on abundance (a) and species richness (b) in the soil seed banks within functional groups ( $\mathrm{L}=$ low grazing intensity and $\mathrm{H}=$ high grazing intensity; UL=upper soil layer and DL=deeper soil layer; bar indicates mean; error bar indicates $\mathrm{sd}$ )

Table 4. Effects of grazing intensity and soil depth on plant abundance in soil seed banks within functional groups

\begin{tabular}{llll}
\hline $\begin{array}{l}\text { response variable: } \\
\text { plant abundance (plants/pot) }\end{array}$ & coefficient $^{1}$ & $\begin{array}{l}95 \% \text { confidence } \\
\text { interval }\end{array}$ & significance \\
\hline grazing intensity & & & \\
$\quad$ grasses & 0.96 & {$[0.67,1.38]$} & 0.850 \\
forbs & 0.53 & {$[0.38,0.74]$} & $<0.001$ \\
legumes & 0.57 & {$[0.37,0.88]$} & 0.011 \\
grass-likes & 0.50 & {$[0.22,1.17]$} & 0.110 \\
ligneous species & 0.52 & {$[0.09,3.06]$} & 0.471 \\
soil depth & & & \\
grasses & 3.95 & {$[2.78,5.61]$} & $<0.001$ \\
forbs & 1.54 & {$[1.10,2.16]$} & 0.012 \\
legumes & 2.58 & {$[1.64,4.07]$} & $<0.001$ \\
grass-likes & 6.26 & {$[2.78,14.10]$} & $<0.001$ \\
$\quad$ ligneous species & 0.67 & {$[0.15,3.03]$} & 0.607 \\
\hline
\end{tabular}

${ }^{1}$ coefficient for the response variable is L/H for grazing intensity and UL/DL for soil depth (L=low grazing intensity and $\mathrm{H}=$ high grazing intensity; $\mathrm{UL}=$ upper soil layer and $\mathrm{DL}=$ deeper soil layer)

seed banks (Figure 3-a and Table 4). However, plant abundance within the other functional groups did not differ between grazing intensities. Plant abundance within all functional groups in the soil seed banks, except within that of the ligneous species, differed between soil depths (Figure 3-a and Table 4). Within the grasses, annuals werethe most abundant (100 \% of the total for H-sites and $95.4 \%$ for L-sites) and they contributed most to species richness (100 \% of the total for $\mathrm{H}$-sites and $86.7 \%$ for L-sites). 
Effect of grazing on aboveground vegetation and soil seed banks

Species richness within forbs and legumes differed between grazing intensities in the soil seed banks (Figure 3-b and Table 5), but not with the other functional groups. Species richness in the soil seed banks differed between soil depths within all functional groups except ligneous species (Figure 3-b and Table 5).

Table 5. Effects of grazing intensity and soil depth on species richness in soil seed banks within functional groups

\begin{tabular}{llll}
\hline $\begin{array}{l}\text { response variable: } \\
\text { species richness (species/pot) }\end{array}$ & coefficient $^{1}$ & $\begin{array}{l}\text { 95\% confidence } \\
\text { interval }\end{array}$ & significance \\
\hline grazing intensity & & & \\
$\quad$ grasses & 1.22 & {$[0.92,1.60]$} & 0.160 \\
forbs & 0.65 & {$[0.50,0.85]$} & 0.002 \\
legumes & 0.55 & {$[0.34,0.88]$} & 0.013 \\
grass-likes & 0.76 & {$[0.40,1.43]$} & 0.389 \\
$\quad$ Ligneous species & 0.58 & {$[0.17,1.98]$} & 0.383 \\
soil depth & & & \\
grasses & 2.59 & {$[1.92,3.49]$} & $<0.001$ \\
forbs & 1.63 & {$[1.24,2.13]$} & $<0.001$ \\
legumes & 2.17 & {$[1.33,3.51]$} & 0.002 \\
grass-likes & 3.51 & {$[1.84,6.69]$} & $<0.001$ \\
Ligneous species & 0.83 & {$[0.25,2.71]$} & 0.753 \\
\hline
\end{tabular}

${ }^{1}$ coefficient for the response variable is $\mathrm{L} / \mathrm{H}$ for grazing intensity and UL/DL for soil depth (L=low grazing intensity and $\mathrm{H}=$ high grazing intensity; $\mathrm{UL}=$ upper soil layer and $\mathrm{DL}=$ deeper soil layer)

\subsubsection{Dissimilarity between soil seed bank and aboveground vegetation and between $H$ and $L$ sites}

More species were found in the aboveground vegetation than in the soil seed banks (Table 6). The number of species per functional group was also higher in the aboveground vegetation than in the soil seed banks, except for the grass-likes. The

Table 6. Species number in aboveground vegetation and in soil seed banks

\begin{tabular}{|c|c|c|c|c|c|c|}
\hline & \multicolumn{2}{|c|}{$\begin{array}{l}\text { aboveground } \\
\text { vegetation }\end{array}$} & \multicolumn{2}{|c|}{$\begin{array}{l}\text { soil seed } \\
\text { banks }\end{array}$} & \multicolumn{2}{|c|}{$\begin{array}{l}\text { in both } \\
\text { (shared) }\end{array}$} \\
\hline & $\mathrm{H}$ & $\mathrm{L}$ & $\mathrm{H}$ & $\mathrm{L}$ & $\mathrm{H}$ & $\mathrm{L}$ \\
\hline \multicolumn{7}{|l|}{ functional groups } \\
\hline grasses & 42 & 47 & 26 & 30 & 21 & 24 \\
\hline annual grasses & 33 & 36 & 26 & 26 & 21 & 20 \\
\hline perennial grasses & 9 & 11 & o & 4 & o & 3 \\
\hline forbs & 72 & 55 & 36 & 24 & 18 & 9 \\
\hline grass-likes & 5 & 8 & 11 & 13 & o & 3 \\
\hline legumes & 31 & 30 & 9 & 9 & 6 & 8 \\
\hline ligneous species & 17 & 21 & 5 & 3 & 1 & 1 \\
\hline
\end{tabular}


Chapter 3

number of species found in both the soil seed bank as well as in in the aboveground vegetation was low.

For the H sites, the average Jaccard's dissimilarity index was $0.85 \pm 0.058(n=8)$. This means that, on average, in H-sites, only $15 \%$ of species were common in both the soil seed banks and the aboveground vegetation. Likewise, for the L-sites, the average Jaccard's dissimilarity index was $0.88 \pm 0.060(n=8)$.

\subsection{Discussion}

The standing biomass differed between H-sites and L-sites, suggesting that high grazing intensity had markedly reduced biomass in the H-sites. This is consistent with the prediction that removal is the direct effect of grazing on pasture (Noy-Meir et al., 1989), given the fact that all sites had annual biomass removal by bushfire. This indicates that the sampling procedure we used to select high grazing and low grazing sites was correct. In the following sections, we discuss the effects of grazing on plant abundance and species richness in aboveground vegetation and in soil seed banks, and species similarity between soil seed banks and aboveground vegetation.

\subsubsection{Grazing effect on aboveground vegetation}

We found no effect of grazing on the overall plant abundance, and on plant abundance within functional groups. This finding is not consistent with Tessema et al. (2011). The latter authors reported bare soils, low basal cover and soil erosion, which could be signs of severe overgrazing. In our study, soil cover was almost complete in L- and H-sites, indicating that the grazing effect was less severe. The fact that plant abundance was not, whereas species richness of forbs was affected by grazing in the present study, might allow the conclusion that species richness is more sensitive to grazing than plant abundance.

The present study shows that sites with higher grazing intensity had increased species richness. This finding was not in line with the common perception that managers of protected areas and decision makers have about grazing. This may be explained by the fact that grazing activity opens the tall-grass dominated vegetation, allowing species underneath to develop, or new species to establish and coexist (Landsberg et al., 2002). Grazing by livestock can create patches (Hendricks et al., 2005) or habitat heterogeneity (Collins et al., 1998) for new species to establish. 
Effect of grazing on aboveground vegetation and soil seed banks

Seeds of new species can come from elsewhere, dispersed by wind, by livestock or other mammals through dung or through seeds stuck to their body (Nacoulma et al., 2011), or they are in the soil seed banks. Grazing opens the grass layer to seeds of annual forbs to germinate and establish. The richness of forb species may increase or decrease in response to grazing (Díaz et al., 2007). Consistent with findings from previous studies (Landsberg et al., 2002; O'Connor, 2005), we found that richness of forb species increased with higher grazing intensity. Such absolute and relative increase in forbs species might be due to their unpalatability related to chemical or physical defences to herbivory (Barton et al., 2010) and to the disappearance of grasses because of grazing.

The increased species richness with higher grazing intensity is consistent with Nacoulma et al. (2011) in West Africa, Oba et al. (2001) in open grazed lands in Kenya and with Rutherford and Powrie (2011) in communal lands of South Africa. This outcome can be explained by the intermediate disturbance hypothesis (Connell, 1978). This suggests that, grazing as a disturbance can promote species coexistence. Most of the species we recorded were annual species. For instance, perennials such as Andropogon gayanus (0.03\% in H-sites and $0.2 \%$ in L-sites) and Loxoderra ledermannii (0.8\% in $\mathrm{H}$-sites and $0.5 \%$ in L-sites) were rare whereas two annuals Microchloa indica (13.2\% in H-sites and 6.6\% in L-sites) and Andropogon pseudapricus (3.9 \% in H-sites and $11.5 \%$ in L-sites) were abundant. It could be that annuals were already abundant in this area, even in the non-grazed pristine vegetation, but it could also be caused by past grazing, since Houessou et al. (2012) found that perennials were more abundant in the core area of the WBR. In that case, it suggests that grazing and trampling by livestock may have destroyed perennials even in the L-sites by damaging their crowns, hence removing organs, which affects them to tiller and then to produce seed later. As regrowth after grazing depends on resources (water, nutrient and light) available to plants or tissues (McNaughton, 1979), in the long term, such perennials will fail to mobilize resources and might disappear. With regard to livestock feeding, perennials are a good dry season forage resource and their low abundance may affect livestock husbandry.

Contrary to our results, other studies found negative effects of grazing on species richness in rangelands in Niger (Hiernaux, 1998), and in Ethiopia (Angassa and Oba, 2010; Tessema et al., 2011). In these studies, high grazing intensity has led to few 
tolerant species to grazing and to physical damage, hence to less species richness (Olff and Ritchie, 1998). It could also be that the area of the present study had more species diversity than that of their study areas, and more species diversity limits the impact of heavy grazing on species richness (Todd and Hoffman, 1999).

\subsubsection{Effects of grazing on soil seed banks}

A high grazing intensity increased plant abundance in soil seed banks, especially abundance of forbs and legumes. This finding is not in line with Tessema et al. (2012) who found a reduction of plant abundance but, as suggested earlier, grazing in their study could have contributed to low basal cover, bare soils and erosion, while the vegetation cover was more intact in our study.

Plant abundance was higher in the upper soil level than in the lower soil level, demonstrating that viable seeds were more abundant near the soil surface. After seed production, seeds first arrive at soil surface where they are captured before entering the deeper soil layer (Thompson and Grime, 1979) and where their dormancy is likely broken by fire or water (Williams et al., 2005). Such effects of vertical distribution on plant abundance in the soil seed banks is consistent with Tessema et al. (2012) in Ethiopia, and Savadogo et al. (2016) in Burkina Faso.

Grazing had no effect on the overall species richness in the soil seed banks in the W Biosphere Reserve. However, within functional groups, a higher grazing intensity increased species richness of forbs and legumes in the soil seed banks. Species richness in soil seed banks depends on the seed productivity and species richness of present and previous plant communities (O'Connor and Pickett, 1992). Therefore, the increase of species richness of forbs germinated from the soil seed bank experiment might partly reflect the increase of species richness of forbs due to grazing, in the aboveground vegetation. Indeed, forbs species were more prevalent in the highly grazed sites than in the lowly grazed sites in the aboveground vegetation. However, the high dissimilarity between forbs and legumes in the soil seed banks and in the aboveground vegetation suggests that other processes played a key role in the pattern observed in our study (see Table 6). For example seed persistence in the soil and seed viability over time are also important features for seed to germinate (Thompson and Grime, 1979). Our finding that higher grazing intensity increased species richness for forbs and legumes (but not overall species richness) in the seed banks is consistent with Dreber and Esler (2011) but contradicts results from 
Effect of grazing on aboveground vegetation and soil seed banks

Tessema et al. (2012). High species richness in soil seed banks from highly grazed sites may reflect high species richness promoted by grazing in the aboveground vegetation, as discussed in the previous section.

More species germinated from the upper soil level than from the lower soil level demonstrating that viable seeds of more species were more abundant near the soil surface. Seeds in the upper layer are more likely to have their dormancy broken by fire or water than seeds in the deeper layer (Williams et al., 2005). Such effect of vertical distribution on species richness is consistent with Savadogo et al. (2016) in Burkina Faso and with Tessema et al. (2012) in Ethiopia.

Seeds germinated from the soils sampled were dominated by herbaceous species, mostly annual grasses and forbs (Table 6). This pattern is consistent with previous studies (Savadogo et al., 2016; Tessema et al., 2012). More herbaceous species in soil seed banks may be due to the ability of herbaceous seeds dispersed by wind and water to move further from the dispersal point (Savadogo et al., 2016). The presence of annual species in the soil seed banks is more likely due to their higher productive seed output (Scott et al., 2010) compared to perennials, which often propagate vegetatively (O'connor, 1996). Once minimised or disappeared, the restoration potential of perennial grasses from the soil seed bank is expected to be relatively limited in the study area, as it was found in rangelands of South Africa (Seymour et al., 2010).

\subsubsection{Dissimilarity between soil seed bank and aboveground species}

Results show high dissimilarity in species composition between soil seed bank and aboveground vegetation in $\mathrm{H}$-sites as well as in L-sites. This dissimilarity is due to the absence of aboveground species in the soil seed banks and vice versa. The low similarity found in the WBR, a savannah-woodland (dominant vegetation) subject to regular fires, can be explained by results presented by Hopfensperger (2007). Her review shows a low similarity between soil seed bank and vegetation composition in all tropical and temperate forests, and a high similarity in aged grasslands. The low similarity in forests was explained by two main reasons. First, after a disturbance, like a fire, pioneer species produce persistent seeds that remain in the seed bank, but are outcompeted over time because they are, for example, shade intolerant. Succession species, on the contrary, produce transient seed banks, that are present for less than a year. Second, a low similarity can be due to a relatively large seed size, 
and hence predation, of late succession species. The low similarity found in grazing areas in the WBR, therefore, might be an indication for the occurrence of disturbances, e.g. fires, in the past and present.

The fact that species composition of soil seed bank and aboveground vegetation were so dissimilar might also imply that the origin of species in the aboveground vegetation is multiple: not only the soil seed bank, but also other locations provide seeds through dispersion by wind and animals (Thompson and Grime, 1979).

Besides a low similarity between soil seed bank and aboveground vegetation, we also found that soil seed banks and aboveground vegetation were both dominated by annual species (Table 6), even in the L-sites. Whether the low prevalence of perennials in L-sites can be attributed to high grazing in the past and insufficient time for recovery after termination of grazing, is unknown.

\subsubsection{Implications for management practices}

This study reveals that intermediate grazing intensity increased species diversity. On the basis of this finding we suggest that, from biodiversity perspective, controlled grazing by pastoralists could be considered in some sections of the WBR. Perennial grasses, however, seem to have disappeared already from the aboveground vegetation and from the soil seed banks, which could be due to recent or past grazing. As these perennial species are relevant in preventing erosion (Snyman, 2004) and in providing relatively high quality of fodder in dry season for grazing (Houessou et al., 2012; Nacoulma et al., 2011), restoration of perennial species is desirable. The rarity of perennials in soil seed banks and aboveground vegetation implies that human intervention is needed for the restoration of perennials.

\subsubsection{Limitations of the study}

In this study, some limitations should be acknowledged. Indeed, because of the high heterogeneity of the savannah habitat (Tongway and Ludwig, 2005), more sampling sites could have improved representativeness of the whole region. Vandvik et al. (2016) found that more samples yield better similarity between aboveground vegetation and soil seed banks. Because of the habitat heterogeneity, more than two levels of grazing intensity could have better reflected the actual dynamics of plant communities in response to grazing. Moreover, data collected during many years are needed to make a strong conclusion about the observed pattern on species diversity 
Effect of grazing on aboveground vegetation and soil seed banks

in the WBR. Nevertheless, our study shows interesting insight in plant community responses to grazing in the WBR.

Regarding the soil seed bank study, most of the annual species are dormant following seed dispersal, until a fire event breaks their dormancy. Soil seed bank samples were collected before fire events in the study area, because we needed to know species in the aboveground vegetation. This implies that more germinated seeds may be found if seeds have passed the fire event before their collection.

\subsection{Conclusion}

In this study, we investigated the effect of grazing intensity on abundance and species richness in the aboveground vegetation and in the soil seed bank. Higher grazing intensity had no effect on plant abundance, but increased forb species richness in the aboveground vegetation. Higher grazing intensity had a positive effect on plant abundance and species richness in the soil seed banks. We found different responses to grazing across functional groups, in the aboveground vegetation and in the soil seed banks. A high dissimilarity of species was detected between the aboveground and soil seed banks, suggesting occurrence of fires in the recent past. Annual species dominated aboveground vegetation and soil seed banks. Our results suggest that at an intermediate grazing intensity level, as experienced in the WBR, species diversity may increase. We conclude, therefore, that controlled grazing by livestock with a program to re-introduce perennial species in the WBR could benefit species diversity.

\section{Acknowledgements}

The research was funded by the Netherlands organisation for international cooperation in higher education (NUFFIC) under the grant NFP-PhD 322/2012 and the Animal Production Systems group of Wageningen University \& Research. The first author would like to thank Yacoubou Boni for assistance in botanical identification and Orou Gandé Gaoue for useful suggestions and comments on an earlier draft of this manuscript. 


\section{Supplementary Material A}

\begin{tabular}{|c|c|c|c|c|}
\hline Species & Family & $\begin{array}{l}\text { Functional } \\
\text { group }\end{array}$ & Abundance & $\begin{array}{l}\text { \% } \\
\text { abundance }\end{array}$ \\
\hline Spermacoce radiata & Rubiaceae & forb & 8261 & 15.296 \\
\hline Tephrosia pedicellata & Fabaceae & legume & 6518 & 12.069 \\
\hline Microchloa indica & Poaceae & grass & 5295 & 9.804 \\
\hline Andropogon pseudapricus & Poaceae & grass & 4240 & 7.851 \\
\hline Zornia glochidiata & Fabaceae & legume & 2913 & $5 \cdot 394$ \\
\hline Loudetia togoensis & Poaceae & grass & 2108 & 3.903 \\
\hline Triumfetta pentandra & Malvaceae & forb & 2047 & 3.790 \\
\hline Hyparrhenia involucrata & Poaceae & grass & 1810 & $3 \cdot 351$ \\
\hline Aristida kerstingii & Poaceae & grass & 1682 & 3.114 \\
\hline Spermacoce stachydea & Rubiaceae & forb & 1660 & 3.074 \\
\hline Sporobolus festivus & Poaceae & grass & 1614 & 2.989 \\
\hline Spermacoce ruelliae & Rubiaceae & forb & 1470 & 2.722 \\
\hline Setaria pumila & Poaceae & grass & 1223 & 2.265 \\
\hline Schoenefeldia gracilis & Poaceae & grass & 1222 & 2.263 \\
\hline Tripogon minimus & Poaceae & grass & 1055 & 1.953 \\
\hline Pennisetum pedicellatum & Poaceae & grass & 865 & 1.602 \\
\hline Cochlospermum tinctorium & Bixaceae & forb & 762 & 1.411 \\
\hline Diheteropogon hagerupii & Poaceae & grass & 747 & 1.383 \\
\hline Brachiaria lata & Poaceae & grass & 542 & 1.004 \\
\hline Pennisetum polystachion & Poaceae & grass & 455 & 0.842 \\
\hline Euclasta condylotricha & Poaceae & grass & 384 & 0.711 \\
\hline Mitracarpus villosus & Rubiaceae & forb & 365 & 0.676 \\
\hline Schizachyrium delicatum & Poaceae & grass & 364 & 0.674 \\
\hline Loxoderra ledermannii & Poaceae & grass & 339 & 0.628 \\
\hline Chamaecrista mimosoides & Fabaceae & legume & 334 & 0.618 \\
\hline Brachiaria stigmatisata & Poaceae & grass & 325 & 0.602 \\
\hline Englerastrum gracillimum & Lamiaceae & forb & 296 & 0.548 \\
\hline Setaria verticillata & Poaceae & grass & 276 & 0.511 \\
\hline Digitaria argillacea & Poaceae & grass & 258 & 0.478 \\
\hline Tristachya superba & Poaceae & grass & 197 & 0.365 \\
\hline Biophytum petersianum & Oxalidaceae & forb & 181 & 0.335 \\
\hline Sporobolus pectinellus & Poaceae & grass & 174 & 0.322 \\
\hline Acroceras amplectens & Poaceae & grass & 172 & 0.318 \\
\hline Grewia cissoides & Malvaceae & forb & 159 & 0.294 \\
\hline Schizachyrium urceolatum & Poaceae & grass & 146 & 0.270 \\
\hline Combretum nigricans & Combretaceae & ligneous & 129 & 0.239 \\
\hline Brachiaria villosa & Poaceae & grass & 119 & 0.220 \\
\hline Schizachyrium brevifolium & Poaceae & grass & 118 & 0.218 \\
\hline Platostoma africanum & Lamiaceae & forb & 116 & 0.215 \\
\hline Andropogon fastigiatus & Poaceae & grass & 111 & 0.206 \\
\hline Pandiaka angustifolia & Amaranthaceae & forb & 98 & 0.181 \\
\hline Cassia obtusifolia & Fabaceae & legume & 94 & 0.174 \\
\hline Hyptis suaveolens & Lamiaceae & forb & 87 & 0.161 \\
\hline
\end{tabular}


Effect of grazing on aboveground vegetation and soil seed banks

\begin{tabular}{|c|c|c|c|c|}
\hline Species & Family & $\begin{array}{l}\text { Functional } \\
\text { group }\end{array}$ & Abundance & $\begin{array}{l}\text { \% } \\
\text { abundance }\end{array}$ \\
\hline Indigofera leptoclada & Fabaceae & legume & 83 & 0.154 \\
\hline Polycarpaea corymbosa & Caryophyllaceae & forb & 83 & 0.154 \\
\hline Sorghastrum bipennatum & Poaceae & grass & 82 & 0.152 \\
\hline Anogeisus leiocarpa & Combretaceae & ligneous & 80 & 0.148 \\
\hline Pupalia lappacea & Amaranthaceae & forb & 74 & 0.137 \\
\hline Melliniella micrantha & Fabaceae & legume & 71 & 0.131 \\
\hline Indigofera leprieurii & Fabaceae & legume & 67 & 0.124 \\
\hline Andropogon gayanus & Poaceae & grass & 63 & 0.117 \\
\hline Combretum collinum & Combretaceae & ligneous & 56 & 0.104 \\
\hline Spermacoce filifolia & Rubiaceae & forb & 56 & 0.104 \\
\hline Bulbostylis hispidula & Cyperaceae & grass-like & 55 & 0.102 \\
\hline Corchorus tridens & Malvaceae & forb & 54 & 0.100 \\
\hline Aspilia helianthoides & Asteraceae & forb & 53 & 0.098 \\
\hline Monechma ciliatum & Acanthaceae & forb & 52 & 0.096 \\
\hline Desmodium gangeticum & Fabaceae & legume & 47 & 0.087 \\
\hline Commelina subulata & Commelinaceae & forb & 46 & 0.085 \\
\hline Sida spinosa & Malvaceae & forb & 46 & 0.085 \\
\hline Indigofera dendroides & Fabaceae & legume & 43 & 0.080 \\
\hline Andropogon chinensis & Poaceae & grass & 36 & 0.067 \\
\hline Kaempferia aethiopica & Zingiberaceae & forb & 34 & 0.063 \\
\hline Panicum pansum & Poaceae & grass & 33 & 0.061 \\
\hline Paspalum scrobiculatum & Poaceae & grass & 33 & 0.061 \\
\hline Flueggea virosa & Phyllanthaceae & ligneous & 32 & 0.059 \\
\hline Polycarpaea eriantha & Caryophyllaceae & forb & 32 & 0.059 \\
\hline Blepharis maderaspatensis & Acanthaceae & forb & 31 & 0.057 \\
\hline Vicoa leptoclada & Asteraceae & forb & 31 & 0.057 \\
\hline Alysicarpus ovalifolius & Fabaceae & legume & 30 & 0.056 \\
\hline Rottboellia cochinchinensis & Poaceae & grass & 30 & 0.056 \\
\hline Waltheria indica & Malvaceae & forb & 29 & 0.054 \\
\hline Alysicarpus glumaceus & Fabaceae & legume & 28 & 0.052 \\
\hline Piliostigma reticulatum & Fabaceae & legume & 28 & 0.052 \\
\hline Striga hermonthica & Orobanchaceae & forb & 28 & 0.052 \\
\hline Guiera senegalensis & Combretaceae & ligneous & 27 & 0.050 \\
\hline Indigofera pilosa & Fabaceae & legume & 25 & 0.046 \\
\hline Digitaria longiflora & Poaceae & grass & 24 & 0.044 \\
\hline Stylosanthes erecta & Fabaceae & legume & 24 & 0.044 \\
\hline Euphorbia convolvuloides & Euphorbiaceae & forb & 22 & 0.041 \\
\hline Ipomoea heterotricha & Convolvulaceae & forb & 22 & 0.041 \\
\hline Lepidagathis anobrya & Acanthaceae & forb & 22 & 0.041 \\
\hline Hygrophila micrantha & Acanthaceae & forb & 20 & 0.037 \\
\hline Sida rhombifolia & Malvaceae & forb & 20 & 0.037 \\
\hline Tephrosia linearis & Fabaceae & legume & 20 & 0.037 \\
\hline Eragrostis tremula & Poaceae & grass & 19 & 0.035 \\
\hline Hyperthelia dissoluta & Poaceae & grass & 19 & 0.035 \\
\hline
\end{tabular}




\begin{tabular}{|c|c|c|c|c|}
\hline Species & Family & $\begin{array}{l}\text { Functional } \\
\text { group }\end{array}$ & Abundance & $\begin{array}{l}\% \\
\text { abundance }\end{array}$ \\
\hline Loudetia flavida & Poaceae & grass & 19 & 0.035 \\
\hline Solenostemon latifolius & Lamiaceae & forb & 19 & 0.035 \\
\hline Cyperus amabilis & Cyperaceae & grass-like & 18 & 0.033 \\
\hline $\begin{array}{l}\text { Stereospermum } \\
\text { kunthianum }\end{array}$ & Bignoniaceae & ligneous & 18 & 0.033 \\
\hline Dichrostachys cinerea & Fabaceae & legume & 17 & 0.031 \\
\hline Polygala arenaria & Polygalaceae & forb & 17 & 0.031 \\
\hline Alysicarpus rugosus & Fabaceae & legume & 16 & 0.030 \\
\hline Combretum fragrans & Combretaceae & ligneous & 16 & 0.030 \\
\hline Lepidagathis collina & Acanthaceae & forb & 16 & 0.030 \\
\hline Terminalia avicennioides & Combretaceae & ligneous & 16 & 0.030 \\
\hline Andropogon shirensis & Poaceae & grass & 15 & 0.028 \\
\hline Crossopteryx febrifuga & Rubiaceae & ligneous & 15 & 0.028 \\
\hline Chloris pilosa & Poaceae & grass & 14 & 0.026 \\
\hline Digitaria horizontalis & Poaceae & grass & 14 & 0.026 \\
\hline Feretia apodanthera & Rubiaceae & ligneous & 14 & 0.026 \\
\hline Indigofera senegalensis & Fabaceae & legume & 14 & 0.026 \\
\hline Vernonia purpurea & Asteraceae & forb & 14 & 0.026 \\
\hline Tephrosia flexuosa & Fabaceae & legume & 13 & 0.024 \\
\hline Boerhavia erecta & Nyctaginaceae & forb & 12 & 0.022 \\
\hline Hexalobus monopetalus & Annonaceae & ligneous & 12 & 0.022 \\
\hline Phaulopsis ciliata & Acanthaceae & forb & 12 & 0.022 \\
\hline Acacia ataxacantha & Fabaceae & legume & 11 & 0.020 \\
\hline Crotalaria macrocalyx & Fabaceae & legume & 11 & 0.020 \\
\hline Detarium microcarpum & Fabaceae & legume & 11 & 0.020 \\
\hline Euphorbia heterophylla & Euphorbiaceae & forb & 11 & 0.020 \\
\hline Pavonia senegalensis & Malvaceae & forb & 11 & 0.020 \\
\hline Pteleopsis suberosa & Combretaceae & ligneous & 11 & 0.020 \\
\hline Tephrosia bracteolata & Fabaceae & legume & 11 & 0.020 \\
\hline Sporobolus pyramidalis & Poaceae & grass & 10 & 0.019 \\
\hline Vitellaria paradoxa & Sapotaceae & ligneous & 10 & 0.019 \\
\hline Acacia macrostachya & Fabaceae & legume & 9 & 0.017 \\
\hline Ampelocissus grantii & Vitaceae & forb & 9 & 0.017 \\
\hline Andropogon tectorum & Poaceae & grass & 9 & 0.017 \\
\hline Bombax costatum & Malvaceae & ligneous & 9 & 0.017 \\
\hline Lonchocarpus laxiflorus & Fabaceae & legume & 9 & 0.017 \\
\hline Schwenckia americana & Solanaceae & forb & 9 & 0.017 \\
\hline Sida urens & Malvaceae & forb & 9 & 0.017 \\
\hline Bidens pilosa & Asteraceae & forb & 8 & 0.015 \\
\hline Hibiscus asper & Malvaceae & forb & 8 & 0.015 \\
\hline Oldenlandia corymbosa & Rubiaceae & forb & 8 & 0.015 \\
\hline Tephrosia platycarpa & Fabaceae & legume & 8 & 0.015 \\
\hline Vernonia cinerea & Asteraceae & forb & 8 & 0.015 \\
\hline Acacia hockii & Fabaceae & legume & 7 & 0.013 \\
\hline Aristida adscensionis & Poaceae & grass & 7 & 0.013 \\
\hline
\end{tabular}


Effect of grazing on aboveground vegetation and soil seed banks

\begin{tabular}{|c|c|c|c|c|}
\hline Species & Family & $\begin{array}{l}\text { Functional } \\
\text { group }\end{array}$ & Abundance & $\begin{array}{l}\% \\
\text { abundance }\end{array}$ \\
\hline Chasmopodium caudatum & Poaceae & grass & 7 & 0.013 \\
\hline Cyperus distans & Cyperaceae & grass-like & 7 & 0.013 \\
\hline Evolvulus alsinoides & Convolvulaceae & forb & 7 & 0.013 \\
\hline Indigofera congolensis & Fabaceae & legume & 7 & 0.013 \\
\hline Melanthera elliptica & Asteraceae & forb & 7 & 0.013 \\
\hline Tinnea barteri & Lamiaceae & ligneous & 7 & 0.013 \\
\hline Combretum glutinosum & Combretaceae & ligneous & 6 & 0.011 \\
\hline Gardenia ternifolia & Rubiaceae & ligneous & 6 & 0.011 \\
\hline Ipomoea coscinosperma & Convolvulaceae & forb & 6 & 0.011 \\
\hline Kyllinga erecta & Cyperaceae & grass-like & 6 & 0.011 \\
\hline Phyllanthus amarus & Phyllanthaceae & forb & 6 & 0.011 \\
\hline Stylochaeton hypogaeus & Araceae & forb & 6 & 0.011 \\
\hline Stylochaeton lancifolius & Araceae & forb & 6 & 0.011 \\
\hline Aspilia rudis & Asteraceae & forb & 5 & 0.009 \\
\hline Eragrostis ciliaris & Poaceae & grass & 5 & 0.009 \\
\hline Ipomoea eriocarpa & Convolvulaceae & forb & 5 & 0.009 \\
\hline Lantana rhodesiensis & Verbenaceae & forb & 5 & 0.009 \\
\hline Rhytachne rottboellioides & Poaceae & grass & 5 & 0.009 \\
\hline Scleria tessellata & Cyperaceae & grass-like & 5 & 0.009 \\
\hline Acacia dudgeoni & Fabaceae & legume & 4 & 0.007 \\
\hline Annona senegalensis & Annonaceae & ligneous & 4 & 0.007 \\
\hline Ctenium elegans & Poaceae & grass & 4 & 0.007 \\
\hline Indigofera hirsuta & Fabaceae & legume & 4 & 0.007 \\
\hline Pterocarpus erinaceus & Fabaceae & legume & 4 & 0.007 \\
\hline Rotala tenella & Lythraceae & forb & 4 & 0.007 \\
\hline Acanthospermum hispidum & Asteraceae & forb & 3 & 0.006 \\
\hline Ceratotheca sesamoides & Pedaliaceae & forb & 3 & 0.006 \\
\hline Dioscorea praehensilis & Dioscoreaceae & forb & 3 & 0.006 \\
\hline Hyparrhenia smithiana & Poaceae & grass & 3 & 0.006 \\
\hline Leucas martinicensis & Lamiaceae & forb & 3 & 0.006 \\
\hline $\begin{array}{l}\text { Monocymbium } \\
\text { ceresiiforme }\end{array}$ & Poaceae & grass & 3 & 0.006 \\
\hline Mukia maderaspatana & Cucurbitaceae & forb & 3 & 0.006 \\
\hline Oldenlandia herbacea & Rubiaceae & forb & 3 & 0.006 \\
\hline Pseudocedrela kotschyi & Meliaceae & ligneous & 3 & 0.006 \\
\hline Setaria sp. & Poaceae & grass & 3 & 0.006 \\
\hline Tamarindus indica & Fabaceae & legume & 3 & 0.006 \\
\hline Wissadula rostrata & Malvaceae & forb & 3 & 0.006 \\
\hline Burkea africana & Fabaceae & legume & 2 & 0.004 \\
\hline Cissus gracilis & Vitaceae & forb & 2 & 0.004 \\
\hline Commelina erecta & Commelinaceae & forb & 2 & 0.004 \\
\hline Cyanotis longifolia & Commelinaceae & forb & 2 & 0.004 \\
\hline Cyperus flabelliformis & Cyperaceae & grass-like & 2 & 0.004 \\
\hline Hoslundia opposita & Lamiaceae & forb & 2 & 0.004 \\
\hline Indigofera secundiflora & Fabaceae & legume & 2 & 0.004 \\
\hline
\end{tabular}




\begin{tabular}{|c|c|c|c|c|}
\hline Species & Family & $\begin{array}{l}\text { Functional } \\
\text { group }\end{array}$ & Abundance & $\begin{array}{l}\% \\
\text { abundance }\end{array}$ \\
\hline Ipomoea filicaulis & Convolvulaceae & forb & 2 & 0.004 \\
\hline Kyllinga squamulata & Cyperaceae & grass-like & 2 & 0.004 \\
\hline Setaria barbata & Poaceae & grass & 2 & 0.004 \\
\hline Strychnos spinosa & Loganiaceae & ligneous & 2 & 0.004 \\
\hline Vigna racemosa & Fabaceae & legume & 2 & 0.004 \\
\hline Wahlenbergia hirsuta & Campanulaceae & forb & 2 & 0.004 \\
\hline Achyranthes aspera & Amaranthaceae & forb & 1 & 0.002 \\
\hline $\begin{array}{l}\text { Amorphophallus } \\
\text { abyssinicus }\end{array}$ & Araceae & forb & 1 & 0.002 \\
\hline $\begin{array}{l}\text { Amorphophallus } \\
\text { flavovirens }\end{array}$ & Araceae & forb & 1 & 0.002 \\
\hline Aneilema pomeridianum & Commelinaceae & forb & 1 & 0.002 \\
\hline Cassia absus & Fabaceae & legume & 1 & 0.002 \\
\hline Cayratia gracilis & Vitaceae & forb & 1 & 0.002 \\
\hline Ceropegia nigra & Apocynaceae & forb & 1 & 0.002 \\
\hline Chlorophytum pusillum & Asparagaceae & forb & 1 & 0.002 \\
\hline Chlorophytum togoense & Asparagaceae & forb & 1 & 0.002 \\
\hline Cissus populnea & Vitaceae & forb & 1 & 0.002 \\
\hline Cleome viscosa & Cleomaceae & forb & 1 & 0.002 \\
\hline Commelina nigritana & Commelinaceae & forb & 1 & 0.002 \\
\hline Crinum zeylanicum & Amaryllidaceae & forb & 1 & 0.002 \\
\hline Cyperus compressus & Cyperaceae & grass-like & 1 & 0.002 \\
\hline $\begin{array}{l}\text { Dactyloctenium } \\
\text { aegypticum }\end{array}$ & Poaceae & grass & 1 & 0.002 \\
\hline Desmodium ramosissimum & Fabaceae & legume & 1 & 0.002 \\
\hline Dombeya buettneri & Malvaceae & ligneous & 1 & 0.002 \\
\hline Echinochloa colona & Poaceae & grass & 1 & 0.002 \\
\hline Eragrostis turgida & Poaceae & grass & 1 & 0.002 \\
\hline Euphorbia kouandenensis & Euphorbiaceae & forb & 1 & 0.002 \\
\hline Gardenia aqualla & Rubiaceae & ligneous & 1 & 0.002 \\
\hline Gardenia erubescens & Rubiaceae & ligneous & 1 & 0.002 \\
\hline Hymenocardia acida & Phyllanthaceae & ligneous & 1 & 0.002 \\
\hline Indigofera bracteolata & Fabaceae & legume & 1 & 0.002 \\
\hline Indigofera sp. & Fabaceae & legume & 1 & 0.002 \\
\hline Indigofera stenophylla & Fabaceae & legume & 1 & 0.002 \\
\hline Kohautia grandiflora & Rubiaceae & forb & 1 & 0.002 \\
\hline Kyllinga pumila & Cyperaceae & grass-like & 1 & 0.002 \\
\hline Lannea acida & Anacardiaceae & ligneous & 1 & 0.002 \\
\hline Ludwigia hyssopifolia & Onagraceae & forb & 1 & 0.002 \\
\hline Pandiaka involucrata & Amaranthaceae & forb & 1 & 0.002 \\
\hline Piliostigma thonningii & Fabaceae & legume & 1 & 0.002 \\
\hline Polygala grandiflora & Polygalaceae & forb & 1 & 0.002 \\
\hline Striga asiatica & Orobanchaceae & forb & 1 & 0.002 \\
\hline Tragia senegalensis & Euphorbiaceae & forb & 1 & 0.002 \\
\hline Zehneria hallii & Cucurbitaceae & forb & 1 & 0.002 \\
\hline
\end{tabular}


Effect of grazing on aboveground vegetation and soil seed banks

\section{Supplementary Material B}

\begin{tabular}{|c|c|c|c|c|}
\hline Species & Family & $\begin{array}{l}\text { Functional } \\
\text { group }\end{array}$ & abundance & $\begin{array}{l}\text { \% } \\
\text { abundance }\end{array}$ \\
\hline Aeschynomene indica & Fabaceae & legume & 6 & 0.37 \\
\hline Ageratum conyzoides & Asteraceae & forb & 5 & 0.31 \\
\hline Alysicarpus rugosus & Fabaceae & legume & 1 & 0.06 \\
\hline Andropogon fastigiatus & Poaceae & grass & 17 & 1.06 \\
\hline Andropogon gayanus & Poaceae & grass & 3 & 0.19 \\
\hline Andropogon pseudapricus & Poaceae & grass & 20 & 1.25 \\
\hline Andropogon schirensis & Poaceae & grass & 2 & 0.12 \\
\hline Aristida kerstingii & Poaceae & grass & 16 & 1.00 \\
\hline Ascolepis protea & Cyperaceae & grass-like & 31 & 1.94 \\
\hline Ascolepis pusilla & Cyperaceae & grass-like & 22 & 1.37 \\
\hline Bacopa floribunda & Plantaginaceae & forb & 3 & 0.19 \\
\hline Biophytum petersianum & Oxalidaceae & forb & 13 & 0.81 \\
\hline Blumea laciniata & Asteraceae & forb & 14 & 0.87 \\
\hline Boerhavia erecta & Nyctaginaceae & forb & 1 & 0.06 \\
\hline Brachiaria lata & Poaceae & grass & 7 & 0.44 \\
\hline Brachiaria stigmatisata & Poaceae & grass & 4 & 0.25 \\
\hline Brachiaria villosa & Poaceae & grass & 8 & 0.50 \\
\hline Bulbostylis barbata & Cyperaceae & grass-like & 2 & 0.12 \\
\hline Bulbostylis hispidula & Cyperaceae & grass-like & 1 & 0.06 \\
\hline Chamaecrista mimosoides & Fabaceae & legume & 12 & 0.75 \\
\hline Chloris pilosa & Poaceae & grass & 3 & 0.19 \\
\hline Cleome viscosa & Cleomaceae & forb & 4 & 0.25 \\
\hline Corchorus tridens & Malvaceae & forb & 8 & 0.50 \\
\hline $\begin{array}{l}\text { Crepidorhopalon } \\
\text { schweinfurthii }\end{array}$ & Linderniaceae & forb & 1 & 0.06 \\
\hline Cyperus amabilis & Cyperaceae & grass-like & 38 & 2.37 \\
\hline Cyperus pustulatus & Cyperaceae & grass-like & 15 & 0.94 \\
\hline Cyperus rotundus & Cyperaceae & grass-like & 2 & 0.12 \\
\hline Dactyloctenium aegyptium & Poaceae & grass & 2 & 0.12 \\
\hline Desmodium gangeticum & Fabaceae & legume & 1 & 0.06 \\
\hline Digitaria argillacea & Poaceae & grass & 110 & 6.87 \\
\hline Digitaria gayana & Poaceae & grass & 1 & 0.06 \\
\hline Digitaria horizontalis & Poaceae & grass & 24 & 1.50 \\
\hline Diheteropogon hagerupii & Poaceae & grass & 16 & 1.00 \\
\hline Eleusine indica & Poaceae & grass & 5 & 0.31 \\
\hline Englerastrum gracillinum & Lamiaceae & forb & 1 & 0.06 \\
\hline Eragrostis asper & Poaceae & grass & 1 & 0.06 \\
\hline Eragrostis ciliaris & Poaceae & grass & 5 & 0.31 \\
\hline Eragrostis tremula & Poaceae & grass & 1 & 0.06 \\
\hline Eragrostis turgida & Poaceae & grass & 2 & 0.12 \\
\hline Euclasta condylotricha & Poaceae & grass & 2 & 0.12 \\
\hline Euphorbia hirsuta & Euphorbiaceae & forb & 448 & 27.98 \\
\hline Ficus exasperata & Moraceae & ligneous & 3 & 0.19 \\
\hline Ficus gnaphalocarpa & Moraceae & ligneous & 7 & 0.44 \\
\hline
\end{tabular}




\begin{tabular}{|c|c|c|c|c|}
\hline Species & Family & $\begin{array}{l}\text { Functional } \\
\text { group }\end{array}$ & abundance & $\begin{array}{l}\text { \% } \\
\text { abundance }\end{array}$ \\
\hline Ficus ingens & Moraceae & ligneous & 2 & 0.12 \\
\hline Fimbristylis ferruginea & Cyperaceae & grass-like & 1 & 0.06 \\
\hline Flueggea virosa & Phyllanthaceae & ligneous & 4 & 0.25 \\
\hline Hibiscus asper & Malvaceae & forb & 2 & 0.12 \\
\hline Hyparrhenia involucrata & Poaceae & grass & 25 & 1.56 \\
\hline Hyptis suaveolens & Lamiaceae & forb & 2 & 0.12 \\
\hline Indigofera congolensis & Fabaceae & legume & 1 & 0.06 \\
\hline Indigofera leptoclada & Fabaceae & legume & 1 & 0.06 \\
\hline Indigofera pulchra & Fabaceae & legume & 4 & 0.25 \\
\hline Indigofera stenophylla & Fabaceae & legume & 7 & 0.44 \\
\hline Ipomoea dichroa & Convolvulaceae & forb & 2 & 0.12 \\
\hline Ipomoea eriocarpa & Convolvulaceae & forb & 1 & 0.06 \\
\hline Ipomoea vagens & Convolvulaceae & forb & 4 & 0.25 \\
\hline Kyllinga debilis & Cyperaceae & grass-like & 1 & 0.06 \\
\hline Kyllinga squamulata & Cyperaceae & grass-like & 29 & 1.81 \\
\hline Leptadenia hastata & Apocynaceae & forb & 2 & 0.12 \\
\hline Leucas martinicensis & Lamiaceae & forb & 2 & 0.12 \\
\hline Loudetia togoensis & Poaceae & grass & 7 & 0.44 \\
\hline Loudetiopsis kerstingï & Poaceae & grass & 4 & 0.25 \\
\hline Ludwigia abyssinica & Onagraceae & forb & 3 & 0.19 \\
\hline Ludwigia hyssopifolia & Onagraceae & forb & 4 & 0.25 \\
\hline Mariscus alternifolius & Cyperaceae & grass-like & 1 & 0.06 \\
\hline Mariscus cylindristachyus & Cyperaceae & grass-like & 28 & 1.75 \\
\hline Melliniella micrantha & Fabaceae & legume & 2 & 0.12 \\
\hline Melochia corchorifolia & Malvaceae & forb & 2 & 0.12 \\
\hline Microchloa indica & Poaceae & grass & 17 & 1.06 \\
\hline Mitracarpus villosus & Rubiaceae & forb & 3 & 0.19 \\
\hline Mitragyna inermis & Rubiaceae & ligneous & 1 & 0.06 \\
\hline Mnesithea granularis & Poaceae & grass & 5 & 0.31 \\
\hline Mollugo nudicaulis & Molluginaceae & forb & 42 & 2.62 \\
\hline Mytracarpus villosus & Rubiaceae & forb & 10 & 0.62 \\
\hline Oldenlandia capensis & Rubiaceae & forb & 1 & 0.06 \\
\hline Oldenlandia corymbosa & Rubiaceae & forb & 5 & 0.31 \\
\hline Oldenlandia herbacea & Rubiaceae & forb & 55 & 3.44 \\
\hline Pandiaka angustifolia & Amaranthaceae & forb & 2 & 0.12 \\
\hline Panicum pansum & Poaceae & grass & 5 & 0.31 \\
\hline Paspalum scrobiculatum & Poaceae & grass & 1 & 0.06 \\
\hline Pavonia senegalensis & Malvaceae & forb & 1 & 0.06 \\
\hline Pennisetum pedicellatum & Poaceae & grass & 16 & 1.00 \\
\hline Peristrophe bicalyculata & Acanthaceae & forb & 3 & 0.19 \\
\hline Phyllantus amarus & Phyllanthaceae & forb & 1 & 0.06 \\
\hline Physallis angulata & Solanaceae & forb & 3 & 0.19 \\
\hline Platostoma africana & Lamiaceae & forb & 1 & 0.06 \\
\hline Polycarpaea eriantha & Caryophyllaceae & forb & 1 & 0.06 \\
\hline
\end{tabular}


Effect of grazing on aboveground vegetation and soil seed banks

\begin{tabular}{|c|c|c|c|c|}
\hline Species & Family & $\begin{array}{l}\text { Functional } \\
\text { group }\end{array}$ & abundance & $\begin{array}{l}\text { \% } \\
\text { abundance }\end{array}$ \\
\hline Portulaca oleracea & Portulacaceae & forb & 60 & 3.75 \\
\hline Pycreus flavescens & Cyperaceae & grass-like & 3 & 0.19 \\
\hline Pycreus nitidus & Cyperaceae & grass-like & 41 & 2.56 \\
\hline Rottboellia cochinchinensis & Poaceae & grass & 1 & 0.06 \\
\hline Schizachyrium brevifolium & Poaceae & grass & 10 & 0.62 \\
\hline Schizachyrium delicatum & Poaceae & grass & 3 & 0.19 \\
\hline Schoenefeldia gracilis & Poaceae & grass & 31 & 1.94 \\
\hline Schoenoplectus senegalensis & Cyperaceae & grass-like & 6 & 0.37 \\
\hline Setaria pumila & Poaceae & grass & 114 & 7.12 \\
\hline Setaria verticillata & Poaceae & grass & 3 & 0.19 \\
\hline Sorghastrum bipennatum & Poaceae & grass & 1 & 0.06 \\
\hline Spermacoce filifolia & Rubiaceae & forb & 3 & 0.19 \\
\hline Spermacoce radiata & Rubiaceae & forb & 21 & 1.31 \\
\hline Spermacoce ruelliae & Rubiaceae & forb & 1 & 0.06 \\
\hline Spermacoce stachydea & Rubiaceae & forb & 2 & 0.12 \\
\hline Sporobolus festivus & Poaceae & grass & 5 & 0.31 \\
\hline Sporobolus pectinellus & Poaceae & grass & 2 & 0.12 \\
\hline Striga hermonthica & Orobanchaceae & forb & 2 & 0.12 \\
\hline Stylosanthes fructicosa & Fabaceae & legume & 1 & 0.06 \\
\hline Tacca leontopetaloides & Dioscoreaceae & forb & 1 & 0.06 \\
\hline Tephrosia linearis & Fabaceae & legume & 3 & 0.19 \\
\hline Tephrosia pedicellata & Fabaceae & legume & 54 & $3 \cdot 37$ \\
\hline Tephrosia platycarpa & Fabaceae & legume & 1 & 0.06 \\
\hline Thelepogon elegans & Poaceae & grass & 1 & 0.06 \\
\hline Triumfetta pentandra & Malvaceae & forb & 13 & 0.81 \\
\hline Vernonia pumila & Asteraceae & forb & 1 & 0.06 \\
\hline Vicoa leptoclada & Asteraceae & forb & 5 & 0.31 \\
\hline Zornia glochidiata & Fabaceae & legume & 10 & 0.62 \\
\hline
\end{tabular}




\section{Chapter 4}

Traditional ecological knowledge underlying herding decisions of pastoralists

Tamou C, de Boer IJM, Ripoll Bosch R, Oosting SJ

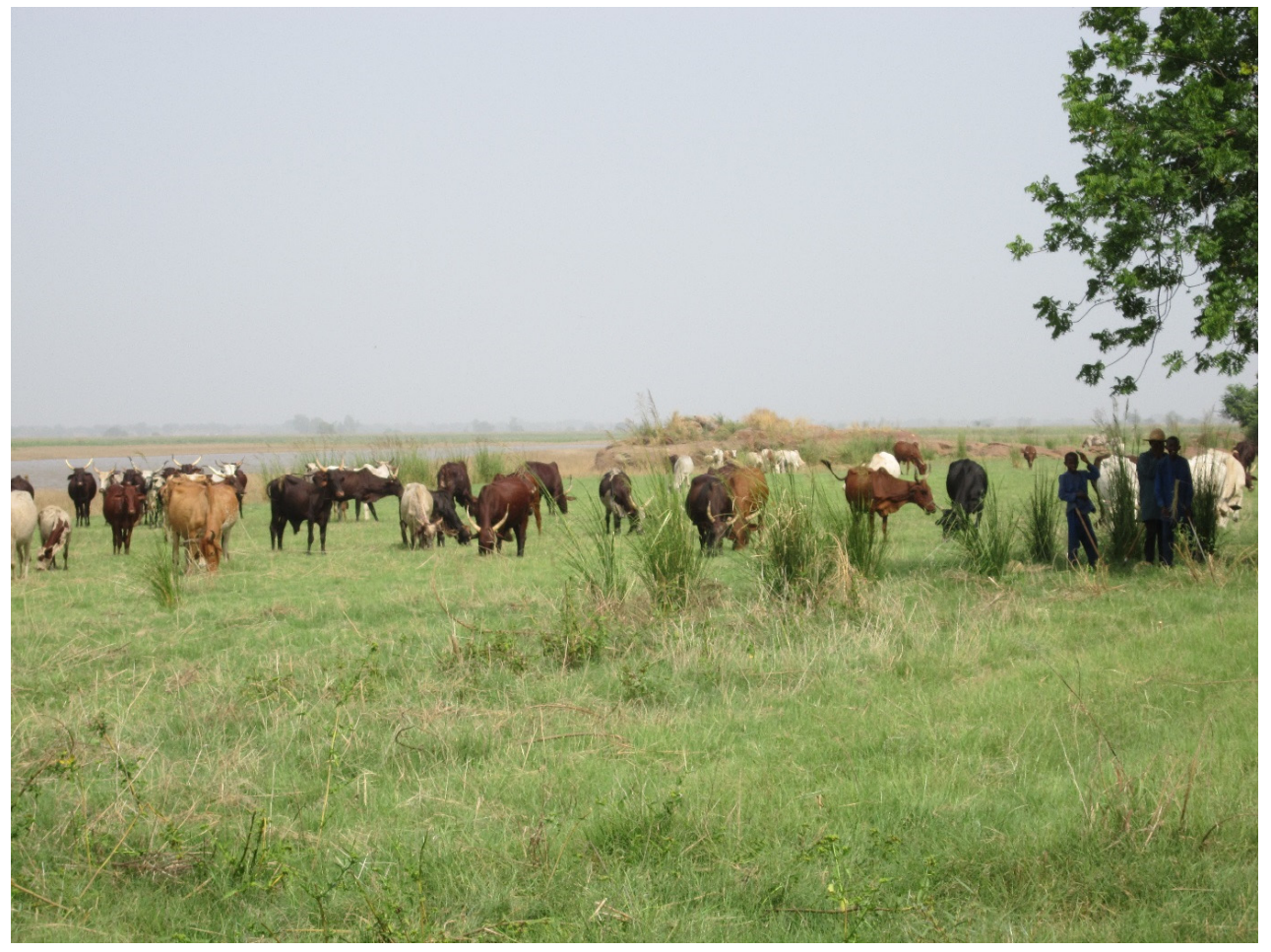

Herders grazing cattle near the Niger River

Under revision at Animal. The International Journal of Animal Biosciences 


\section{Abstract}

Pastoralists have traditional ecological knowledge (TEK) of their environment, which is important for their livelihoods and for policies and interventions. Pastoralism is under pressure, however, which may result in a decline of pastoral lifestyle and its related TEK. We, therefore, addressed the following objectives i) to inventorise and assess how pastoralists characterise and value soils and forages in their environment, ii) to analyse how soil, forage and livestock (i.e. cattle) characteristics relate to herding decisions, and iii) to determine whether TEK underlying herding decisions differs across generations. Data were collected through focus groups and individual interviews with 72 pastoralists, belonging to three generations and to three agroecological zones. Using a three-point scale (high, medium, low), four grasses and three tree forages were assessed in terms of nutritional quality for milk, meat, health and strength. Using their own visual criteria, pastoralists identified five different soils, which they selected for herding at different times of the year. Pokuri was the best soil because of its good drainage capacity, whereas Karaal was the worst because forage hardly grows on it. Perennials, such as Andropogon gayanus and Loxoderra ledermannii, were of high nutritional quality, whereas annuals such as Andropogon pseudapricus and Hyparrhenia involucrata were of low nutritional quality. Afzelia africana had high quality for milk production, whereas Khaya senegalensis had the highest quality for meat, health and strength. Pastoralists first used soil, then forage and finally livestock characteristics in their herding decisions. Pastoralists' TEK was not associated with their generations, but with their agroecological zones. This study suggests that pastoralists had common and detailed TEK about soils, forages and livestock characteristics, underlying their herding decisions. To conclude, pastoralists use a holistic approach, combining soil, vegetation and livestock TEK in herding decisions. Such TEK can guide restoration or improvement of grazing lands, and land use planning.

Key-words: pastoralism, forage quality, grazing lands, soils, cattle 


\section{Implications}

This study suggests that pastoralists apply common and detailed traditional ecological knowledge (TEK) about soils, forages and livestock characteristics to make their herding decisions, and used a holistic approach, combining soil, vegetation and livestock TEK in herding decisions. Pastoralists' TEK about soils, forages and livestock can guide land use planning. This information can be valuable in the buffer zone of the $\mathrm{W}$ Biosphere Reserve, in order to select suitable grazing lands and the season for herding, and improve current grazing land with high quality grasses (i.e. Andropogon gayanus) and tree leguminous forages (i.e. Khaya senegalensis). 


\subsection{Introduction}

Pastoralists move their livestock between territories in order to find fresh pastures on which to graze their livestock. Well-known pastoralist populations in Africa include Touareg, Fulbe (or Fulani) and Maasai (Barfield, 1993). Through many years of experience in their environment, pastoralists have developed extensive knowledge that guides a sustainable use and management of their surrounding resources (Blench, 2001). Such knowledge, referred to as traditional ecological knowledge (TEK), is defined as the cumulative body of knowledge, practices, and beliefs regarding the relations of living things to their environment, that evolves by adaptive processes, and is handed down through generations (Berkes et al., 2000). It is currently acknowledged that TEK is essential to preserve pastoralism and its cultural heritage. Moreover, policies and interventions related to range- and grassland use could benefit from understanding the pastoralists' TEK (Fratkin and Mearns, 2003).

At present, pastoralists' culture and lifestyle is threatened and consequently also their TEK (Thornton, 2010). One key challenge for pastoralists is the loss and fragmentation of pastoral lands, watering points and livestock routes (Reid et al., 2004), due to increased competition for land by i.a. increased land use for cropping (Ayantunde et al., 2008b). An example of this is seen inside, and especially in the periphery of the Biosphere Reserve of $\mathrm{W}$ in Benin Republic (WBR). In this region, an ongoing trend of land use change from a natural land cover of forest and savannah into cropland is observed, and competition between pastoralism and crop farming, and between pastoralism and nature conservation are cause of conflict (Tamou et al., 2015). The transition in pastoral life, which could potentially be associated with land use changes and marginalization, could affect TEK in pastoral communities. In addition, it is observed that younger generations abandon pastoral life and migrate to cities (Ayantunde et al., 2011). As a consequence, TEK is no longer handed down from one generation to the next and may get lost over time.

TEK of pastoralists in Africa has been extensively studied. Some studies focused on knowledge related to grassland degradation (Behmanesh et al., 2015; Kassahun et al., 2008; Roba and Oba, 2009), others on knowledge of grassland quality (Dabasso et al., 2012; Oba and Kaitira, 2006), or of botanic species diversity and their palatability for livestock (Ayantunde et al., 2008a; Davis, 2005; Oba and Kaitira, 2006). Studies 
Traditional ecological knowledge

explicitly focussing on herding decisions by pastoralists related to TEK of their grazing landscape are not reported, to our knowledge. Herding is referred to as moving and grazing of livestock, in the grazing landscape consisting of soils, forages and livestock. We hypothesize that herding decisions are based on assessment of soil characteristics, forage characteristics and livestock characteristics. Understanding how such characteristics relate to location and moment of herding may give insights in how pastoralists use natural resources and may give scope for policy development regarding, e.g. sustainable land use planning and grassland conservation. Since it is also unknown what the TEK about soils and forages is among pastoralists in and around the WBR and whether or not the TEK is still handed down from old to young generations, the study presented here had the following objectives: i) to inventorise and assess how pastoralists characterise and value soils and forages in their environment, ii) to analyse how soil, forage and livestock characteristics relate to herding decisions, and iii) to determine whether TEK underlying herding decisions differs across generations.

\subsection{Materials and methods}

\subsubsection{Study area}

This study was carried out in the WBR (former National Park of W), in North Benin. The WBR ( $11^{\circ} 26^{\prime}$ to $12^{\circ} 26^{\prime} \mathrm{N}$ and $2^{\circ} 17^{\prime}$ to $3^{\circ}$ o5' E) comprises about $56 \%$ of the W Transboundary Biosphere Reserve located in the countries of Benin, Niger and Burkina Faso, and covers about $5632 \mathrm{~km}^{2}$. The vegetation of the WBR consists of tree, shrub and woodland savannah, gallery forest and wetland. This vegetation allows the presence of several wildlife species, such as lions, cheetahs, elephants, buffaloes, waterbucks, monkeys, and birds. The regional water supply comes from the Niger River and its tributaries: the Alibori, Mekrou and Sota watercourses. The climate of the WBR is characterised by two main seasons: a rainy season from mid-May to October, with an average minimum daily temperature of $12{ }^{\circ} \mathrm{C}$, an average maximum daily temperature of $25^{\circ} \mathrm{C}$, and precipitation ranging from 700 to $1000 \mathrm{~mm}$; and a dry season from November to mid-May, with an average minimum daily temperature of $30^{\circ} \mathrm{C}$, an average maximum daily temperature of $40^{\circ} \mathrm{C}$ and hardly any precipitation (Billand et al., 2005). During the first part of the dry season, from November to February, a dry dusty wind blows through the North of Benin, also referred to as harmattan, which boosts the drying process of natural pasture. The harmattan 
facilitates burning of dried pasture, either from prescribed early fire used to reduce fuel accumulation or from late bush fire.

In Benin, five districts border the WBR, with the main economic activities being crop farming and livestock production. The WBR and its surrounding land are located in the so-called agro-pastoral contact zone in West Africa (De Haan et al., 1990), indicating that land is suitable for crop farming and livestock farming, enabling competition for land (Tamou et al., 2015). Crop farmers get their main income from production of cereals (maize, sorghum, millet, rice), roots and tubers (yam, cassava, potato and sweet potato), legumes (groundnut, beans, soybean and bambara bean), vegetables (tomato, pepper, okra, pumpkin) and cotton, and possess oxen for ploughing. They belong to the following ethnic groups: Baatonu, Dendi, Monkole and Goumantche. In contrast, pastoralists obtain their main income from livestock and livestock products, and belong to the Fulbe ethnic group. The Fulbe pastoralists are dwellers of the districts surrounding the WBR and some of them come from the bordering countries Burkina Faso, Niger and Nigeria, during the dry season (Tamou, 2002).

In this study, three agro-ecological zones were distinguished: the Sudanian zone in the south, the Sahelo-Sudanian zone in the north and the intermediate zone in between the north and south regions. Average rainfall ranged from $1000 \mathrm{~mm} / \mathrm{year}$ in the south, to $700 \mathrm{~mm} /$ year in the north. Selection of the three agro-ecological zones was done to cover possible variation of pastoralists' TEK about herding across the study area. In each agro-ecological zone, one village and two adjacent hamlets were selected to conduct the study. Hence, 9 communities were selected for data collection in the present study. The first author was introduced to Fulbe pastoralists' leaders by field officers of the livestock service of the Ministry of Agriculture in each of the villages and hamlets. Research objectives and methodologies were discussed with these pastoralists' leaders and their permission to conduct the study was obtained.

\subsubsection{Data collection}

Data were collected between November 2014 and April 2015. Information was derived from three sources: i) rapid appraisals, ii) focus group discussions (FGDs), and iii) individual interviews (Figure 1). 
Traditional ecological knowledge

\subsubsection{Rapid appraisals}

Informal interviews about pastoralists' herding knowledge were held with 5 field officers of the livestock services working around the WBR. The first author also collected information from rapid appraisals (Chambers, 1994), during field visits to the 9 communities selected for data collection. On the basis of these rapid appraisals items about pastoralists' herding knowledge were identified that would be discussed in the focus groups.

\subsubsection{Focus group discussion}

FGDs were held in each of the 9 selected communities. The number of participants ranged from 15 to 20 people per focus group; participants were all men, and most of the time elders who were members of the village or hamlet council. Participants were all cattle keepers. The objective of the FGDs were: to introduce the study, to include pastoralists in the study design, and to have focus group discussions (McLafferty, 2004) with them about TEK underlying herding decisions. In addition, the FGDs were used to select relevant age classes to study the generation effect on TEK underlying herding decisions and to develop a semi-structured questionnaire for the individual interviews. The first author facilitated the discussions in French which was then translated into the local language (Fulfulde) by a trained interpreter. FGDs lasted from 1.5 to 2 hours and were audio-recorded. The dimensions described hereunder were derived from the FGDs. The first author made a final selection of items within each dimension on basis of compliance between FGDs. The final selection was then discussed with pastoralists' representatives for confirmation.

a) Relevant age classes for assessing traditional knowledge about herding. During FGDs, pastoralists agreed that three generations were of relevance (between brackets their Fulfulde name) for study of traditional knowledge of pastoralists' herding: the young (Alwasibey) generation (18-30 years old), the mid (Dotibey) generation (4060 years old) and the old (Nahebey) generation ( $>60$ years old).

b) Selection of dimensions in the questionnaire for individual interviews

b.1. soils. FGDs discussed soil types distinguished on basis of relevant characteristics as perceived by pastoralists. The participants of the FGDs were asked to make their own list of criteria and to classify soils according to these criteria. We used the soil names chosen by the pastoralists in their own Fulfulde language. In addition, pastoralists mentioned positive and negative factors influencing the quality of soils 
for forage growth (and consequently for herding) which we included in the questionnaires for individual interviews.

b.2. forages. Participants of the FGDs were asked to list the most important grass and leguminous tree forage species for herding, involving cattle; to indicate the nutritional quality of the most important forage species; to provide the seasonal availability of the various forages; and to establish links between forages and soils. The seasonal variability reflected pastoralists' calendar, which consists of five periods i.e. Seyto, Dungu, Yaawol, Dabuney and Tchendwe (see Table 4 for details). From the inventory of grass and leguminous tree forage species, pastoralists selected four grasses and three leguminous tree forages which they perceived as the most important in regard to herding decisions.

b.3. Herding decisions. FGDs discussed elements, criteria and weighing of criteria for deciding where and when to herd their livestock. Soil, forage and livestock characteristics were considered the most important elements underlying herding decisions.

\subsubsection{Individual interviews}

Based on the outcomes of the FGDs, we developed a semi-structured questionnaire with four sections. The first section assessed the demographic parameters related to herding, such as age of herders, and the length of experience in herding. The second section assessed the interviewees' perception of quality of soils by asking them to mention the best and the worst soil for herding. They were also asked to mention the most important positive factor and the most important negative factor determining quality of soils for forage growth. In the third section, interviewees were asked to score the nutritional quality of the forages important for herding decisions. Interviewees scored the forage species by a three-point scale (low, medium or high) regarding the contribution of forages' nutritional quality to animal production objectives. In the fourth section, interviewees were asked to rank soil, forage and livestock characteristics, in terms of their importance for herding decisions.

Individual interviews were conducted with 24 interviewees (eight per age group) in each of the three villages (hence not in the hamlets) by means of the questionnaire. Interviewees were selected using the snowball technique starting with participants of the FGDs. The inclusion criterion for the interview was that the interviewee should have past or present experience in herding. The interview was held in each 
Traditional ecological knowledge

interviewee's household. Individual interviews lasted between 45 minutes and one hour. The first author asked the questions in French and a trained interpreter translated the questions into the local language.

\subsubsection{Data analysis}

Data analysis consisted of a descriptive analysis of information obtained from FGDs and a statistical analysis of data obtained from the individual interviews (Figure 1).

\subsubsection{Focus group discussions}

The discussions were summarised and the general patterns of the discussions were categorised (Pope and Mays, 1995). These general patterns were then synthesised into an inventory of soils and their characteristics, an inventory of forages and their quality, and a calendar of use of soils and forages.

\subsubsection{Analysis of data of individual interviews}

Age, age at the start of herding, actual experience in herding, potential experience in herding and ratio of actual and potential experience in herding were first tested for normal distribution. Since these parameters were not normally distributed, the Kruskal-Wallis test was used to test for effects of generation and agro-ecological zone on demography of herding. In case of significant effect, the Nemenyi post-hoc test (with chi-square approximation) was used to test for differences between means. The Fisher's exact test was used to test for association between generation or agroecological zone and number of interviewees still herding (active herders) or not. In case of an association, a post-hoc analysis based on pairwise comparison was performed to determine different groups (Mangiafico, 2016).

We combined chi-square and Pearson's standardised residuals, to analyse pastoralists' perception, within each of the four production objectives of grasses, and within each of the four production objectives of tree leguminous forages, separately. Within production objectives we first used chi-square to check for significant associations between the number of interviewees and the score. We then calculated Pearson's standardised residual, which is the deviation of the observed number of interviewees for a given score from its expected value (Agresti, 2007). Pearson's residuals of more than +3 and lower than -3 were considered significant (Agresti, 2007), i.e. indicating that there was a high level of agreement among pastoralists. The Pearson's standardised residual is calculated as followed. 
Residual $=(O-E) / \sqrt{E}$

$O$ is the observed number of interviewees, and $E$ is the expected number of interviewees (Agresti, 2007).

To analyse the importance of soil, forage and livestock characteristics for herding decisions we used the same procedure. Here, Pearson's standardised residual is the deviation of the observed number of interviewees for a given rank from its expected value.

We used Fisher's exact test to test for associations between generation and agroecological zone with regard to i) quality of soils for herding, and positive and negative factors influencing such quality, ii) perception of nutritional quality of forages, and iii) perception of importance of soil, forage and livestock characteristics for herding decisions. In case of an association, a post-hoc analysis based on pairwise comparisons was performed (using the function "pairwiseNominalIndependence" from the package "rcompanion”) to determine different groups (Mangiafico, 2016).

All statistical analyses were done in R 3.3.1 (R Core Team, 2016).

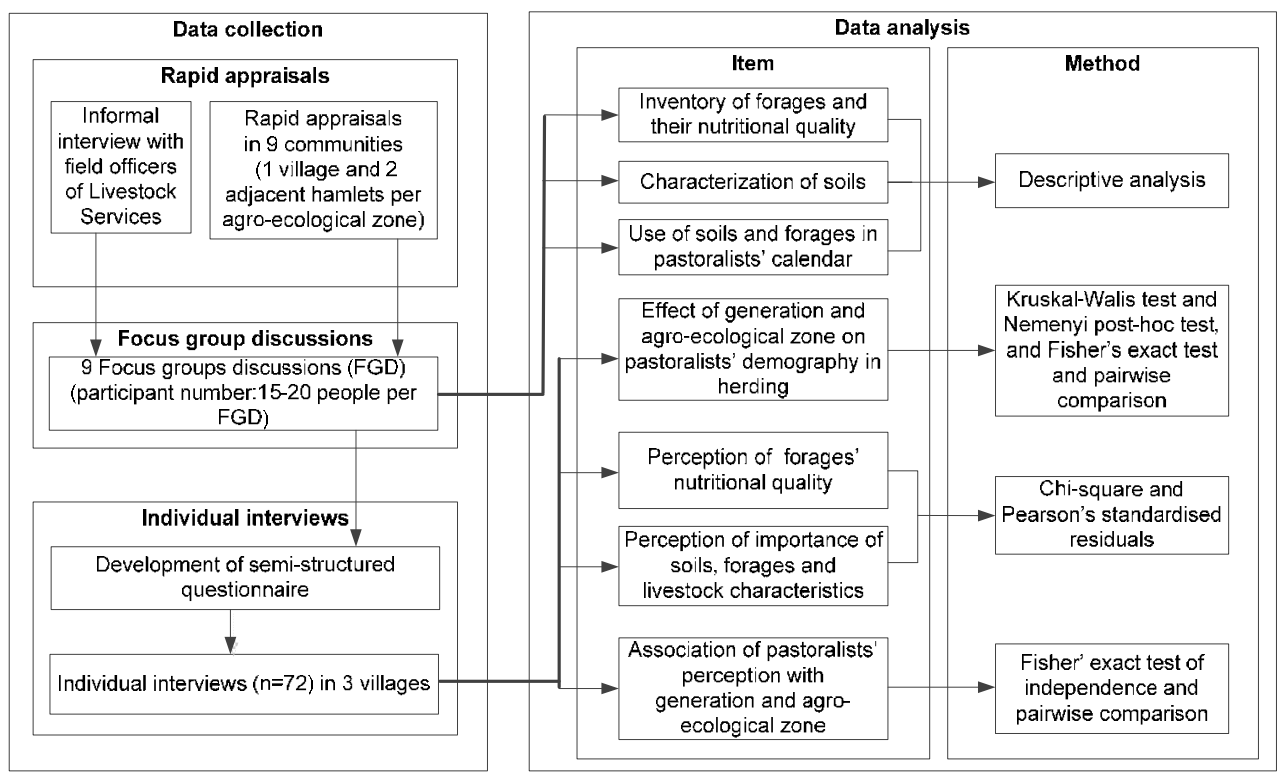

Figure 1. Framework for data collection and analysis (adapted from Oteros Rozas et al. (2013)) 
Traditional ecological knowledge

\subsection{Results}

\subsubsection{Inventory of forages and their qualities}

In the FGDs with pastoralists, the following 10 grasses were mentioned (between brackets their Fulfulde name): Andropogon gayanus (Ranyerey, Seynorey or Kibia), Loxoderra ledermannii (Nardi), Andropogon pseudapricus (Seokorey), Hyparrhenia involucrata (Jokuru), Pennisetum spp. (Buludey), Diheteropogon hagerupii (Garabaal), Echinochloa stagnina (Burugu), Telepogon elegans (Bolagoril), Brachiaria stigmatisata (Paguri) and Tephrosia pedicellata (Dumbaru). The grasses that pastoralists considered most important for herding decisions were A. gayanus and L. ledermannii (perennials), and A. pseudapricus and $H$. involucrata (annuals). Reasons mentioned for selection of these grass species were that the perennials were dominant in the core area of the WBR, whereas the annuals where dominant everywhere in the study area. A. gayanus and $L$. ledermannii were also considered as having good nutritional quality.

Pastoralists mentioned the following leguminous tree forages: Afzelia africana (Warangnanhi), Pterocarpus erinaceus (Banuhi), Kyaha senegalensis (Kayi), Acacia spp. (Giajey), and other tree forages (not leguminous) such as Balanites aegyptica (Giajey), Ficus spp. (Huiki), and Azadirachta indica. The following species were considered most important for herding decisions: A. africana, $P$. erinaceus and $K$. senegalensis, because they were the most harvested by pastoralists and offered to livestock in the dry period. The grasses and leguminous tree forages considered important for herding decisions were selected for inclusion in the individual interviews.

Pastoralists reported the following nutritional qualities of forages: contribution to milk production (milk), meat production (meat), favouring short calving interval, favouring livestock health (health), favouring livestock strength (strength), favouring livestock satiety, and favouring faecal production. From this list, the following qualities were considered most important by FGDs and were selected for the individual interviews: milk, meat, health and strength. Milk and meat are important since they are sources of food (especially protein with high nutritional quality) and income. Health is important since some forages were considered to enhance the health status of the animals, and strength is important since pastoralists perceived that some forages support strength and endurance in walking. This helps livestock to 
remain strong, especially in the dry period, and during long walks in search of good forages.

\subsubsection{Characterisation of soils}

Pastoralists mentioned the five following soils: Yahirey, Yoldey, Pokuri, Baaley and Karaal, which were common in all three agro-ecological zones. Depending on the agro-ecological zone, pastoralists reported different names for similar soils. It was agreed to use the names reported above since they were understood in each of the agro-ecological zones. Table 1 presents the main characteristics of these soils. Water drainage capacity (determining whether water stagnates resulting in land with puddles referred to as wetland or whether water infiltrates), sand and stone content of soil, humus (organic matter content, called Taaki in Fulfulde, which was associated with the ability of a soil to produce forage of good quality), and soil stickiness (which is negatively associated with ease of cattle movement on soils) were characterising soil typology. We found that soil typology followed a toposequence, from riverbank to high altitude. Different forage species dominate the different soil types.

Table 1. Characteristics of soil types distinguished by Fulbe pastoralists in and around the WBR

\begin{tabular}{|c|c|c|c|c|c|}
\hline \multirow[b]{2}{*}{ characteristics } & \multicolumn{5}{|l|}{ soil types } \\
\hline & Yahirey & Yoldey & Pokuri & Baaley & Karaal \\
\hline $\begin{array}{l}\text { drainage } \\
\text { capacity }\end{array}$ & $\begin{array}{l}\text { water usually } \\
\text { stagnates in } \\
\text { rainy season }\end{array}$ & $\begin{array}{l}\text { water often } \\
\text { stagnates in rainy } \\
\text { season }\end{array}$ & $\begin{array}{l}\text { water usually } \\
\text { infiltrates in } \\
\text { rainy season }\end{array}$ & $\begin{array}{l}\text { water } \\
\text { infiltrates }\end{array}$ & $\begin{array}{l}\text { no water even in } \\
\text { rainy season }\end{array}$ \\
\hline sand content & + & + & +++ & ++ & +++ \\
\hline stone content & o & o & + & +++ & ++ \\
\hline humus & +++ & ++ & ++ & + & o \\
\hline stickiness & +++ & +++ & + & o & o \\
\hline topography & $\begin{array}{l}\text { floodable lands } \\
\text { (riverbanks, } \\
\text { ponds) }\end{array}$ & $\begin{array}{l}\text { hydromorphic } \\
\text { soil on flat lands }\end{array}$ & $\begin{array}{l}\text { non- } \\
\text { hydromorphic } \\
\text { on flat lands }\end{array}$ & $\begin{array}{l}\text { hills and } \\
\text { mountains }\end{array}$ & $\begin{array}{l}\text { flat lands or } \\
\text { lateritious lands }\end{array}$ \\
\hline grass species & E. stagnina & $\begin{array}{l}\text { A. gayanus, } \\
\text { A.pseudapricus }\end{array}$ & $\begin{array}{l}\text { A. gayanus, } \\
\text { L. } \\
\text { ledermannii }\end{array}$ & $\begin{array}{l}\text { Pennisetum } \\
\text { spp, } \\
\text { A.gayanus }\end{array}$ & $\begin{array}{l}\text { hardly } \\
\text { T. pedicellata }\end{array}$ \\
\hline
\end{tabular}

$\mathrm{O}=$ absent,$+=$ low,$++=$ medium,$+++=$ high,

Source: FGDs in pastoralists' communities 
Traditional ecological knowledge

\subsubsection{Use of soils and forages in the pastoralists' calendar}

Figure 2 presents the use of soils and of leguminous tree forages in pastoralists' calendar. The calendar was similar for all agro-ecological zones. The period of the year in which each soil is preferred depends on soil moisture which in turn relates to the drainage capacity of the soil. In the rainy season, the soils Yahirey and Yoldey are too wet and pastoralists avoid herding on these soils. Pastoralists reported that livestock on very wet soils do not eat well because they are bothered by tsetse flies, which are abundant on such soils during the rainy season. Consequently, livestock may get sick and produce less milk. Others reported that on wet soils, livestock get sick more often because of a snail, which is abundant in humid lands, and which transmits a disease. Hence, in the rainy season livestock graze on soils such as Pokuri and Baaley which are less wet (i.e. they have good moisture content but without standing water) and where forages are available. In the dry season, the soil Yahirey and Yoldey are preferred for grazing because they have forage and no standing water, whereas forages are too dry, if available at all, on Pokuri and Baaley.

In the dry period, when herbaceous forages are scarce, pastoralists harvest leguminous tree forages as a supplement to feed their livestock. In the pastoralists' calendar, the dry season consists of Dabuney, Tchendwe and Seyto. Harvesting of leguminous tree forage depends on the availability of young and fresh leaves. Nowadays, because of logging, crop farming and overharvesting, these leguminous tree forages have become scarce. Therefore, other trees such as B. aegyptiaca, Acacia spp., Ficus spp., and $A$. indica are harvested during the dry season, although their quality is perceived as lower than that of $A$. Africana and $K$. senegalensis.

After crop harvesting, at the onset of the dry season, crop residues are available and can be used according to verbal contracts between crop farmers and pastoralists. So, throughout the pastoralists' calendar, pastoralists adapt their herding according to soil moisture, and the availability of forages, tree forages and other resources, such as crop residues. 


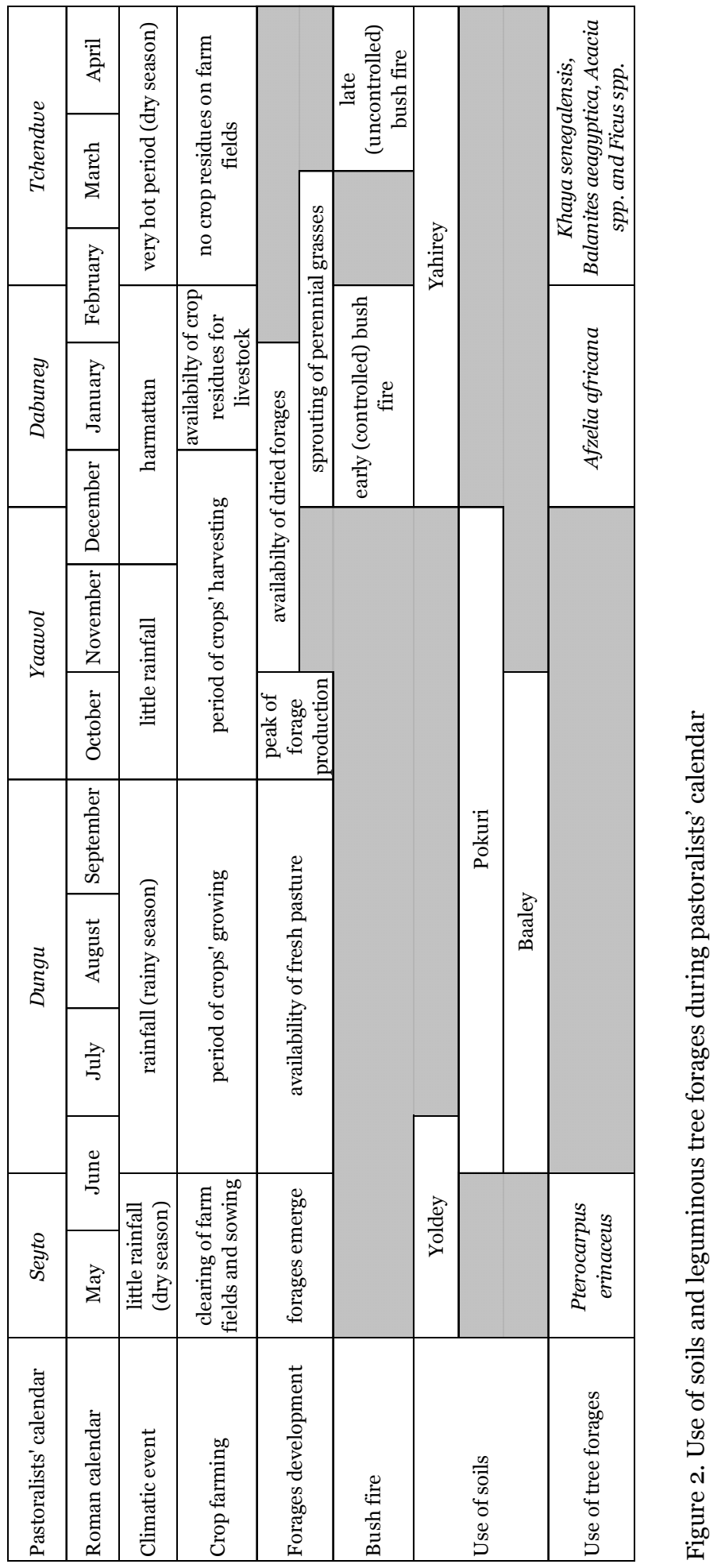


Knowledge underlying herding decisions

\subsubsection{Effect of generation and agro-ecological zones on herding demographics}

Table 2 presents pastoralists' demographic parameters related to herding. Generation had no effect on age at the start of herding. As expected more young (67\%) than mid and old (19\%) pastoralists were still active in herding. Actual herding experience was a fraction of $0.9,0.7$ and 0.6 of the potential herding experience (i.e. the difference between present age and age at start of herding) for young, mid and old generation, respectively. This indicates that the young spent a considerable time of their life herding.

Agro-ecological zone had no effect on demographic parameters of herding.

Table 2. Demographic parameters related to herding across generations of pastoralists and agro-ecological zones in the study area

\begin{tabular}{|c|c|c|c|c|c|c|}
\hline & $\begin{array}{l}\text { age } \\
(\mathrm{yr}(\mathrm{sd}))\end{array}$ & $\begin{array}{l}\text { age of } \\
\text { starting } \\
\text { herding } \\
(\mathrm{yr}(\mathrm{sd}))\end{array}$ & $\begin{array}{l}\text { actual herding } \\
\text { experience } \\
(\mathrm{yr}(\mathrm{sd}))\end{array}$ & $\begin{array}{l}\text { potential } \\
\text { herding } \\
\text { experience } \\
(\mathrm{yr}(\mathrm{sd}))\end{array}$ & $\begin{array}{l}\text { ratio actual } \\
\text { and potential } \\
\text { herding } \\
\text { experience }\end{array}$ & $\begin{array}{l}\text { active } \\
\text { herders }^{\dagger} \\
\text { (n) }\end{array}$ \\
\hline \multicolumn{7}{|c|}{ generations of pastoralists } \\
\hline Young & $25 \cdot 5^{\mathrm{a}}(2.67)$ & $10.9(3.04)$ & $13 \cdot 3^{\mathrm{a}}(4.89)$ & $15 \cdot 3^{\mathrm{a}}(4 \cdot 79)$ & $0.9^{\mathrm{a}}(0.21)$ & $16^{\mathrm{a}}$ \\
\hline Mid & $48.3^{b}(4.67)$ & $11.3(3.64)$ & $25.6^{\mathrm{b}}(10.19)$ & $37.1^{\mathrm{b}}(6.27)$ & $0.7^{\mathrm{b}}(0.24)$ & $5^{\mathrm{b}}$ \\
\hline Old & $68.4^{c}(8.27)$ & $12.8(6.23)$ & $34 \cdot 7^{c}(14 \cdot 37)$ & $55.0^{c}(10.25)$ & $0.6^{b}(0.23)$ & $4^{\mathrm{b}}$ \\
\hline \multicolumn{7}{|c|}{ agro-ecological zones in the study area } \\
\hline South & $48.7(20.02)$ & $11.3(4.51)$ & $24 \cdot 4(14 \cdot 45)$ & $37.6(18.51)$ & $0.7(0.27)$ & 6 \\
\hline Mid & $46.7(17.80)$ & $13.2(5.17)$ & $21.9(11.30)$ & $33.2(17.11)$ & $0.7(0.24)$ & 8 \\
\hline North & $46.9(18.41)$ & $10.5(3.50)$ & $27.3(14.93)$ & $36.6(18.66)$ & $0.8(0.23)$ & 11 \\
\hline
\end{tabular}

Different superscripts within column and within generation or agro-ecological zone indicate significant differences $(\mathrm{P}<0.001)$;

${ }^{\dagger}$ Significant association between generation and number of active herders (Fisher's exact $\mathrm{P}<0.05$ )

\subsubsection{Perception of quality of soils}

Regarding classification of soils, 40 out of the 72 interviewees mentioned that Pokuri was the best soil for herding. They explained this choice by the fact it does not get too wet due to its high rate of water infiltration and that there are good forages present on this soil. In contrast, 49 out of 72 interviewees mentioned that Kaaral was the worst soil, because usually no forage grows on it, or if any, forages are in seldom tufts and of very poor quality.

Regarding soil factors of importance for forage growth, humus (52 out of 72 interviewees) and moisture (18 out of 72 interviewees) were the most positive factors. 
Moisture was defined as the water availability for forage growth and should be distinguished from standing water on the soils, which is a negative soil characteristic (see Table 1). Other positive factors were looseness of soils allowing forages to establish easily, and the absence of stagnating water. Overstocking and soil compaction (due to overstocking, resting and walking, making it difficult for forages to establish) were considered the most negative factors for forage growth, in both quality and quantity. Uncontrolled bush fire (in the dry period) was also mentioned as a negative factor for forage growth because it burns forages' seeds and it destroys soils.

\subsubsection{Perception of the nutritional quality of forages}

Table 3 presents pastoralists' perception of the nutritional quality of the forages. Regarding grasses, pastoralists had a shared (as indicated by Pearson's residual values of higher than +3 or lower than -3) perception about their nutritional qualities. A. gayanus was perceived as being of high quality for meat, health and strength. A. pseudapricus was perceived as being of medium quality for strength; and that $H$. involucrata as being of low nutritional quality for milk, meat, health and strength. Pastoralists' perception of the nutritional quality of L. ledermannii was scattered. Pastoralists perceived perennials (A. gayanus and L. ledermannii) of higher quality than the annuals (A. pseudapricus and $H$. involucrata). Pastoralists reported that after grazing A. gayanus, livestock's coat is always shining, which is a sign of health. During resting, livestock have deep breathing, which is a sign that they are well fed and healthy. In contrast after grazing poor forages, such as $H$. involucrata, livestock will have shallow breathing, which is a sign that they are not well fed, according to the interviewees.

Regarding leguminous tree forages, $K$. senegalensis was perceived as being of high quality for meat, health and strength. $P$. erinaceus was perceived as being of medium quality for health and $A$. africana was perceived as being of high quality for milk, and of low quality for health. Pastoralists explained the low quality for health by the fact that when livestock eat too many leaves of this forage, they are not healthy and they even produce less milk during the next season (wet season, with many fresh forages). Other pastoralists mentioned that livestock bleed from their shoulders, which they considered as unhealthy. 
Knowledge underlying herding decisions

Table 3. Pastoralists' perception of nutritional quality of important forages species (number of interviewees scoring in quality class within production objectives)

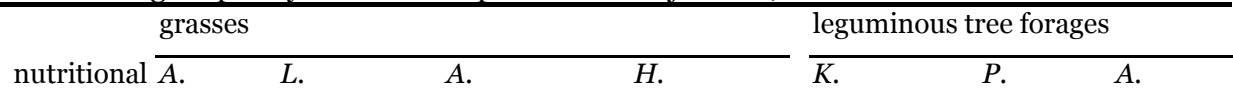

production quality gayanus ledermannii pseudapricus involucrata senegalensis erinaceus africana objective class

\begin{tabular}{llccccccc}
\hline milk & high & 31 & 33 & 22 & 19 & $11^{\beta}$ & $6^{\beta}$ & $65^{\alpha}$ \\
& medium & 36 & 28 & 28 & 19 & 35 & 41 & 5 \\
& low & $5^{\beta}$ & 11 & 22 & $34^{\alpha}$ & 26 & 25 & $2^{\beta}$ \\
meat & high & $63^{\alpha}$ & 32 & $12^{\beta}$ & $8^{\beta}$ & $50^{\alpha}$ & 18 & 29 \\
& medium & 8 & 23 & 32 & 24 & 14 & 35 & 20 \\
& low & $1^{\beta}$ & 17 & 28 & $40^{\alpha}$ & 8 & 19 & 23 \\
\multirow{5}{*}{ health } & high & $64^{\alpha}$ & 35 & 17 & $9^{\beta}$ & $65^{\alpha}$ & $18^{\beta}$ & 25 \\
& medium & $6^{\beta}$ & 27 & 34 & 26 & $5^{\beta}$ & $35^{\alpha}$ & 18 \\
& low & $2^{\beta}$ & 10 & 21 & $37^{\alpha}$ & $2^{\beta}$ & 19 & $29^{\alpha}$ \\
\multirow{5}{*}{ strength } & high & $65^{\alpha}$ & 34 & $8^{\beta}$ & $8^{\beta}$ & $59^{\alpha}$ & 20 & 23 \\
& medium & $6^{\beta}$ & 22 & $37^{\alpha}$ & 18 & 10 & 22 & 18 \\
& low & $1^{\beta}$ & 16 & 27 & $46^{\alpha}$ & $3^{\beta}$ & 30 & 31
\end{tabular}

Number with superscript $\alpha$ indicate Pearson's standardized residuals more than +3 and those with superscript $\beta$ indicate Pearson's standardised residuals less than -3

\subsubsection{Importance of soil, forage and livestock characteristics for herding decisions}

Table 4 presents the importance of soils, forages and livestock characteristics for herding decisions. Soils ranked first, forages second and livestock ranked third regarding pastoralists' perception of the importance of these characteristics for herding decisions.

Table 4. Ranking of soils, forages and livestock with regard to importance for herding decisions (number of interviewees within importance rank-class)

\begin{tabular}{llll}
\hline & \multicolumn{2}{l}{ Importance rank-class } \\
\cline { 2 - 4 } & 1st & 2nd & 3rd \\
\hline soils & $37^{\alpha}$ & 18 & 17 \\
forages & 22 & 35 & 15 \\
livestock & 13 & 19 & $40^{\alpha}$ \\
\hline
\end{tabular}

Number with superscript $\alpha$ indicate Pearson's standardized residuals more than +3 


\subsubsection{Association of pastoralists' perception with generation and agro- ecological zone}

Table 5 presents the associations between generation and perception of the nutritional quality of forages. In some cases there was a difference between generations with regard to perception of quality of forages for a production objective. The old generation scored $H$. involucrata (for meat and health) and A. africana (for strength) lower than the young and mid generation, whereas they scored A. gayanus and L. ledermannii higher than the mid generation for meat.

There was no association between generations and perception of best soil, worst soil and negative factors for soil quality, and ranking of importance of soil and livestock characteristics for herding decisions. However, the young generation considered humus content as most important while the mid generation considered moisture content most important regarding soil quality for forage production. Additionally, the young generation ranked forage characteristics second while the mid generation ranked forage characteristics first with regard to importance for herding decisions.

Table 5. Effect of generation (young, mid and old) on pastoralists' perception of forage quality for the production objectives milk, meat, health and strength

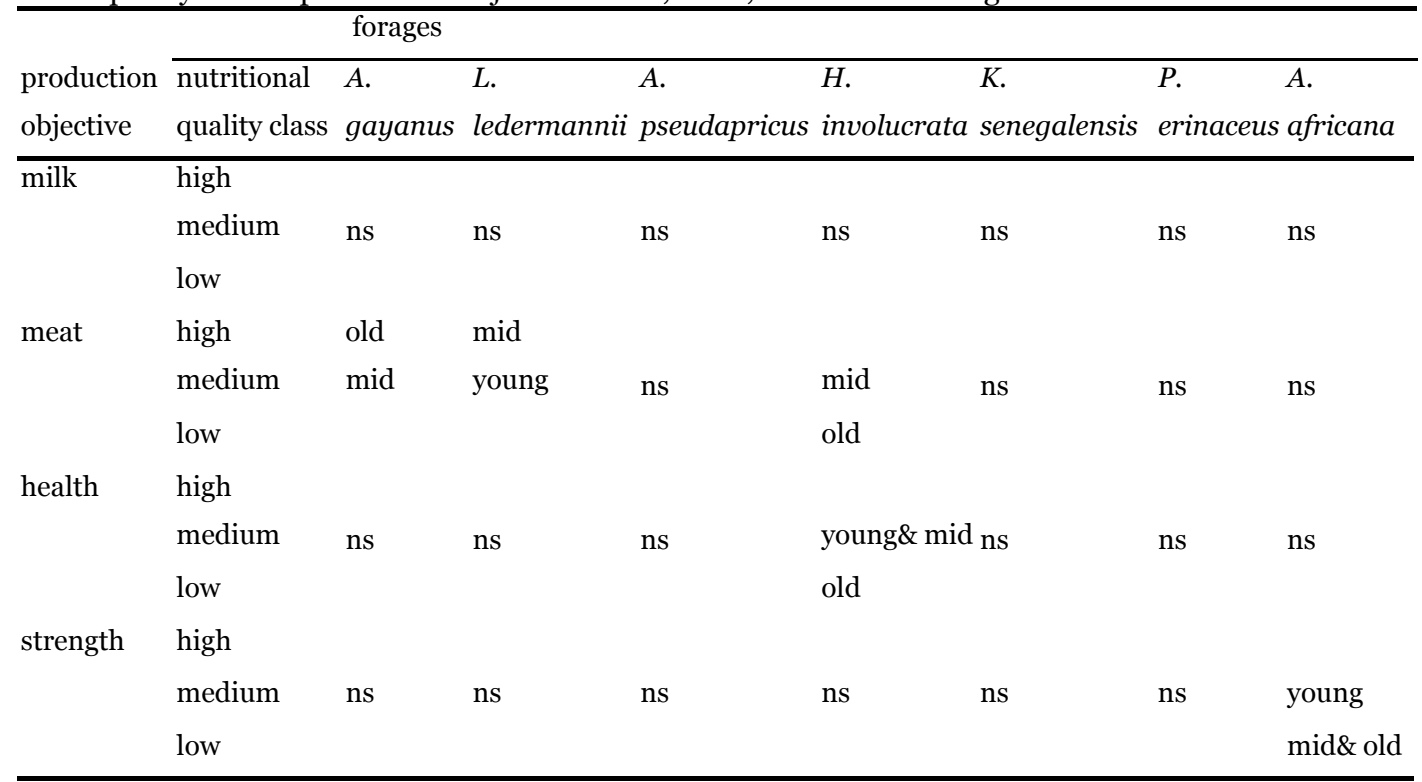

If generation effect is significant, then it is indicated in which nutritional quality class the majority of the generation scored.

ns: not significant $(\mathrm{P}>0.05)$, indicates no generation effect 
Table 6 presents the associations between agro-ecological zones and perception of the nutritional quality of forages. Differences with regard to perception of forages between agro-ecological zones are consistent in the sense that for at least two production objectives $L$. ledermannii, $H$. involucrata, $K$. senegalensis and $P$. erinaceus are perceived as being of lower quality in the north than in the mid and south zones, while A. pseudapricus and A. africana were perceived as being of higher quality in the north than in more southern agro-ecological zones. With regard to perception of best and worst soils and soil characteristics affecting forage production the only difference found was that pastoralists from the south perceived moisture as the most positive soil parameter whereas those from the north instead perceived humus as being most important. There was no association between agroecological zone and perception of importance of soil, forage and livestock characteristics.

Table 6. Effect of agro-ecological zone (south, mid and north) on pastoralists' perception of forage quality for the production objectives milk, meat, health and strength

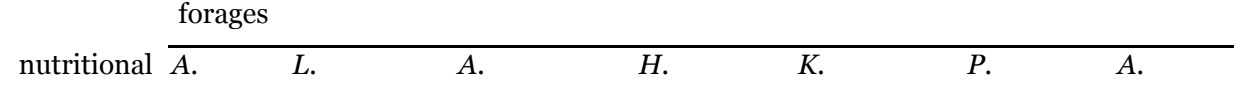

production quality gayanus ledermannii pseudapricus involucrata senegalensis erinaceus africana objective class

\begin{tabular}{|c|c|c|c|c|c|c|c|c|}
\hline \multirow[t]{3}{*}{$\overline{\text { milk }}$} & high & & south\&mid & north & south & south & south & north \\
\hline & medium & \multirow[t]{2}{*}{ ns } & & & south & north & \multicolumn{2}{|c|}{ mid\&north mid } \\
\hline & low & & north & mid & north & north & & south \\
\hline \multirow[t]{3}{*}{ meat } & high & \multirow{3}{*}{$\begin{array}{l}\text { mid } \\
\text { north }\end{array}$} & & south\&north & south & & & \\
\hline & medium & & ns & south\&north & north & south & ns & ns \\
\hline & low & & & mid & north & north & & \\
\hline \multirow[t]{4}{*}{ health } & high & \multirow{4}{*}{ ns } & south\&mid & north & \multirow{4}{*}{ ns } & & \multirow{4}{*}{$\begin{array}{l}\text { south } \\
\text { mid\&north }\end{array}$} & north \\
\hline & medium & & north & south\&mid & & ns & & \\
\hline & low & & & & & & & south \\
\hline & & & & & & & & \&mid \\
\hline \multirow[t]{4}{*}{ strength } & high & \multirow{4}{*}{ ns } & south\&mid & north & \multirow{4}{*}{ ns } & south\&mid & \multirow{2}{*}{ south } & \multirow[t]{2}{*}{ north } \\
\hline & medium & & north & south\&mid & & north & & \\
\hline & \multirow{2}{*}{ low } & & & couth $\&_{\text {mmid }}$ & & & \multirow{2}{*}{$\begin{array}{l}\text { mid\& } \\
\text { north }\end{array}$} & \multirow{2}{*}{$\begin{array}{l}\text { south } \\
\text { \&mid }\end{array}$} \\
\hline & & & & & & & & \\
\hline
\end{tabular}

If effect of agro-ecological zone is significant, then it is indicated in which nutritional quality class the majority of the generation scored.

ns: not significant $(\mathrm{P}>0.05)$, indicates no generation effect 


\subsection{Discussion}

The present study aimed to improve our understanding of pastoralists' TEK related to their herding decisions. Results show that pastoralists have a common and detailed understanding of soil, forage and livestock characteristics, and their herding decisions are based on TEK they have acquired about these characteristics. Forage species are differentially appreciated by pastoralists in northern and southern agroecological zones: A. pseudapricus is more appreciated in the north since it is more abundant there and consequently more important for grazing than in the south. Additionally A. africana is considered the best tree leguminous forage for milk production in all agro-ecological zones, but it has been affected by logging. In the south good alternatives are available (e.g. Andropogon gayanus, Loxoderra ledermannii) while this is not the case in the north. This could explain why herders in the north attribute higher quality to A. africana than in the south. The TEK underlying herding decisions do not differ much between generations. This could be explained by the early involvement of young pastoralists in herding. In the following paragraphs, we discuss pastoralists' TEK about soils, forages and livestock characteristics and the integration of such knowledge in making herding decisions.

\subsubsection{Traditional knowledge about soils, forages and livestock characteristics}

Results show that pastoralists have common and detailed understanding of the soils. The criteria they mentioned for valuing and classifying soils imply that they classify a whole grazing landscape and not only the soil. Their soil classification is based on topography, the forage availability and the risk of disease vectors. Pastoralists' soil classification based on topography is consistent with Oba and Kaitira (2006). Different generations in different agro-ecological zones have highly similar perceptions of positive and negative factors associated with soil suitability for forage production such as humus and moisture. Moreover, overstocking is clearly recognised as a negative factor for forage production, and hence for herding, which implies that pastoralists are aware of the potential negative effects of herding on grassland productivity and grassland degradation.

Our results also show that pastoralists have a common and detailed TEK about the nutritional qualities of forages. A. gayanus was perceived as being of high quality for meat, health and strength. A. pseudapricus was perceived as being of medium 
Knowledge underlying herding decisions

quality for strength; and that $H$. involucrata was perceived as being of low nutritional quality for milk, meat, health and strength. The fact that pastoralists valued $A$. gayanus (perennial grass) more than $A$. pseudapricus and $H$. involucrata (two annual grasses) is consistent with Buldgen and Dieng (1997) in Senegal and Obulbiga and Kaboré-Zoungrana (2007) in Burkina Faso. This indicates that besides knowledge about forage species and grassland dynamics (Gaoue and Ticktin, 2009; Kgosikoma et al., 2012; Oba, 2012), pastoralists know about the nutritional qualities of these forages and even attribute a quality according to a production objective. For instance, quality of leguminous tree forages for milk mentioned by pastoralists was correlated with their content of crude protein as reported in Ouédraogo-Koné et al. (2008) in Burkina Faso.

Pastoralists linked quality of soils and forages to livestock health and to livestock behaviour. Soils of good quality are linked to soils without standing water, with limited risk of contracting diseases such as trypanosomiasis, for which the tsetse fly is the vector (Simo and Rayaisse, 2015), and animal fascioliasis, for which the snail Lymnea natalensis is the vector (Youssao and Assogba, 2002). Consumption of sufficient forages of good quality is linked to the shininess of the cattle's coats and to their manner of breathing (respiration rate) during resting. Shininess of cattle's coat is used as an indicator of animal welfare, suggesting that pastoralists' TEK is consistent with scientific findings. Though there is no scientific support for the relation between consumption of sufficient forages and livestock respiration rate during resting, respiration rate is widely used to measure heat stress of cattle in animal welfare (Gaughan and Mader, 2014; Tresoldi et al., 2016).

\subsubsection{Integration of TEK regarding soil, forage and livestock characteristics underlying herding decisions}

Results showed that pastoralists agree that soils rank first, forages second and livestock third. Therefore, in herding decisions, pastoralists look first at soil characteristics, i.e. they consider whether it is too wet or not. If the soil is not too wet, the next stage of the decision making is to assess the presence of good forages. If good forages are available, then livestock is used mainly to decide whether herding should continue or not, since in practice, pastoralists look at the livestock's behaviour and the condition of their coats during and after grazing: dull coats and livestock acting impatient after a night's rest (restless behaviour) to go out for herding again 
are signs that their feed demands are potentially not being met by grazing. Such restless behaviour might be similar to the high motivation of limited-fed heifers to access feedstuff because of a lack of gut fill or an unsatisfied behavioural need to forage (Greter et al., 2015). This finding suggests that, in making decisions for herding, pastoralists use a holistic approach, which combines soil, vegetation and livestock characteristics, beyond the livestock-vegetation relationship used by ecologists in assessing grassland quality (Roba and Oba, 2009). Our finding suggests that soils with abundance of good pasture but being too wet, may force pastoralists to herd on soils with lower availability and quality of forage.

\section{Acknowledgements}

The research was funded by the Netherlands organisation for international cooperation in higher education (NUFFIC) under the grant NFP-PhD 322/2012 and the Animal Production Systems group of Wageningen University \& Research. The first author would like to thank Fokje Steenstra for assistance with the statistical analyses and Laura Webb for providing comments on an early version of this manuscript. 


\section{Chapter 5}

Understanding roles and functions of cattle breeds for pastoralists in Benin

Tamou C, de Boer IJM, Ripoll Bosch R, Oosting SJ

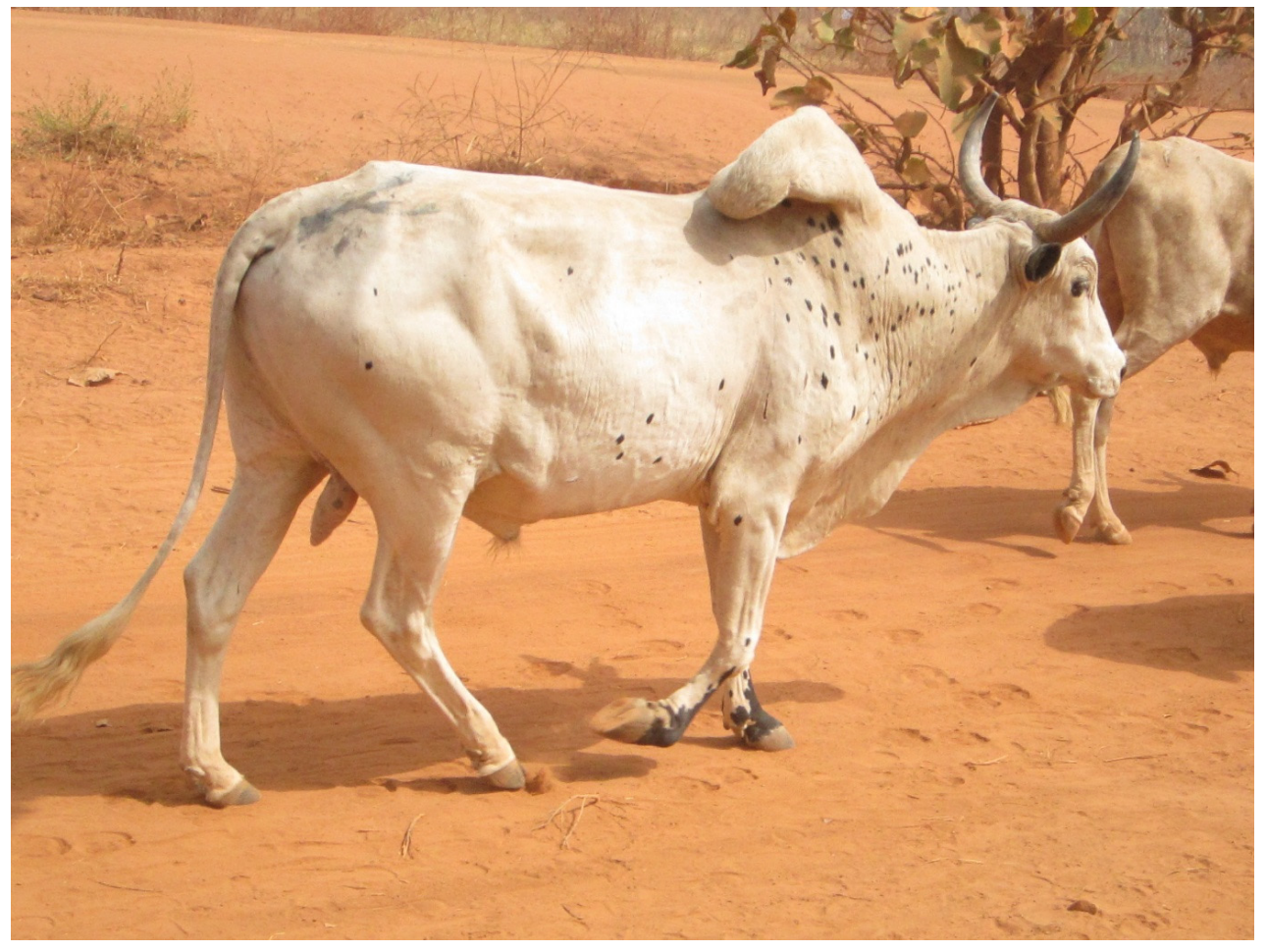

The Jaliji breed

Submitted 


\section{Abstract}

Animal genetic resources (AnGR) are essential for food security and the livelihoods of many pastoralists. However, the AnGR diversity is currently being eroded, as well as the traditional ecological knowledge associated to the use of indigenous breeds and their environment. The objectives of this study were to: i) inventorise indigenous breeds of cattle in Northern Benin and their performance in selected traits, ii) analyse pastoralists' preferences for specific breeds and reasons for that, and iii) determine whether the knowledge about breeds and their traits was transmitted across generations and was consistent across agro-ecological zones. Data were collected doing focus groups discussions and from a semi-structured questionnaire with 72 pastoralists. Interviewees belonged to three generations and three agroecological zones in the periphery of the W Biosphere Reserve in Benin. From the focus groups discussions we identified the most common breeds in the region (i.e. Keteeji, Jaliji, Bodeeji, Tchiwali and Gudali) and the most relevant traits (i.e. milk production, meat production, endurance and tolerance to trypanosomiasis) to assess cattle breeds according to pastoralists. Individual interviewees scored the performance of cattle breeds in the four main traits based on a three-point scale. Finally, we determined the consistency of pastoralists' knowledge across generations and agro-ecological zones. Keteeji was valued for its endurance and tolerance to trypanosomiasis, Bodeeji was highly valued for endurance and Gudali was perceived of high value for meat and milk production, but of low value for endurance. Keteeji was the preferred breed by the majority of the pastoralists (nearly 50\%), and especially for an adaptive trait (i.e. withstanding hunger) instead of a productive one. Gudali was the least preferred breed (11\%). 80\% of pastoralists selected a preferred cattle breed based on non-productive traits, i.e. withstanding hunger, intelligence (more than obedience to herder) or withstanding disease. This study suggests that pastoralists prefer adaptive traits of breeds over production traits to deal with the changing and unfavourable conditions of their environment. Pastoralists' knowledge about breed traits did not differ among generations, but some differences appeared among agro-ecological zones.

Key-words: pastoralists, traditional knowledge, indigenous breeds, cattle traits, Animal Genetic Resources 
Roles and functions of cattle breeds for pastoralists

\subsection{Introduction}

Animal genetic resources (AnGR) are an essential part of the biological basis for world food security, and contribute to the livelihoods of over a billion people (FAO, 2007). AnGR provide insurance against current and future challenges, such as emerging diseases, changes in market demands (Oldenbroek, 1999) and changing environmental conditions, including climate change (FAO, 2007). AnGR also have an important social and cultural role, as they constitute an integral part of traditions in many societies (FAO, 2013). At present, however, AnGR are being eroded as a result of several factors, such as replacement of local breeds by other breeds, indiscriminate cross-breeding, changes in production systems (e.g. specialisation with emphasis on a single productive trait) or changes in socio-economic and environmental circumstances (Gibson et al., 2006). For instance, from the 8774 livestock breeds documented in 2014 around the world, 9\% are extinct and 17\% are classified at risk (FAO, 2015). Animal (and plant) genetic resources are the ultimate non-renewable resource; once gone, they are gone for good (Thornton et al., 2009). Therefore, there is a need to reduce the loss of AnGR and establish programmes for their conservation and sustainable use (FAO, 2007; Gibson et al., 2006). According to the Convention on Biological Diversity (CBD, 2006), not only the biological diversity deserves attention, but also the traditional knowledge associated to it. The traditional knowledge possessed by indigenous and local communities, which generally involves oral transmission (CBD, 2005) (currently under threat! (Tang and Gavin, 2016)), is relevant for the conservation and sustainable use of biological diversity, including crops and livestock (CBD, 2005).

There are two main methods for the conservation of AnGR: In vitro conservation and in vivo conservation. In vitro conservation refers to the conservation of breeds in an artificial environment, in form of gametes or embryos (FAO, 2013), whereas in vivo conservation refers to conservation of breeds through the maintenance of life animal populations (FAO, 2013). In developing countries, FAO recommends in vivo, and in situ conservation of breeds through continued use in the production system in which they evolved, are found and bred (FAO, 2013). Moreover, in situ conservation generally implies less financial resources than in vitro conservation (FAO, 2007). In situ conservation in Africa builds on pastoralists, which are considered the creators and guardians of African livestock breeds, especially ruminants, such as cattle, sheep, 
goats and camels (FAO, 2009; Köhler-Rollefson et al., 2009). Across generations pastoralists have developed and transmitted a body of knowledge about their indigenous breeds and the interaction with their surrounding environment. Within their own production systems, especially where environmental conditions are harsh, indigenous breeds can perform better than exogenous breeds thanks to nonproductive traits, such as resistance to trypanosomiasis or adaptation to heat (Anderson, 2003; Köhler-Rollefson et al., 2009; Ayalew et al., 2003). However, information about which traits are valued by pastoralists and how different breeds perform with regard to these traits is generally lacking, implying a poor characterisation of local breeds (FAO, 2007).

At present, pastoralists' traditional culture and lifestyle is threatened, and consequently also their traditional way of herding (Catley et al., 2013; Thornton, 2010) and, eventually, their traditional knowledge. One key challenge for pastoralists is the loss and fragmentation of pastoral lands, watering points and livestock routes (Reid et al., 2004), due to increased competition for land for example by increased land use for cropping (Ayantunde et al., 2008; Thébaud and Batterbury, 2001). Such changes in grazing land are observed also in and around the $\mathrm{W}$ Biosphere Reserve in Benin (WBR) (Tamou et al., 2016a). Changes in pastoral lifestyle can lead to changes in desired traits, which may lead to loss of indigenous breeds (Hoffmann, 2010). Gaining insight into pastoralists' perception of the indigenous breeds and the associated desired traits is of importance in order to prevent loss of livestock diversity, as well as to understand the roles and functions of the animals and of the overall production system (Van der Zijpp, 2011). So far, it is unknown which indigenous breeds and which traits pastoralists value around the WBR. The objectives of this study were to: i) inventorise indigenous breeds of cattle in Northern Benin and their performance in selected traits, ii) analyse pastoralists' preferences for specific breeds and reasons, and ii) determine whether the knowledge about breeds and their traits was being transmitted across generations and was consistent across agro-ecological zones.

\subsection{Materials and methods}

\subsubsection{Study area}

This study was carried out in the W Biosphere Reserve (WBR; former National Park of W), in North Benin. The WBR ( $11^{\circ} 26^{\prime}$ to $12^{\circ} 26^{\prime} \mathrm{N}$ and $2^{\circ} 17^{\prime}$ to $3^{\circ}$ o5' E) 
Roles and functions of cattle breeds for pastoralists

comprises about $56 \%$ of the W Transboundary Biosphere Reserve located in the countries of Benin, Niger and Burkina Faso, and covers about $5632 \mathrm{~km}^{2}$. The vegetation of the WBR consists of tree, shrub and woodland savannahs, gallery forests and wetlands. This vegetation allows the presence of several wildlife species, such as elephants, lions, buffaloes, cheetahs, waterbucks, monkeys, and birds. The regional water supply comes from the Niger River and its tributaries: the Alibori, Mekrou and Sota watercourses. The climate of the WBR is characterised by two main seasons: a rainy season from mid-May to October, with an average minimum daily temperature of $12{ }^{\circ} \mathrm{C}$, an average maximum daily temperature of $25^{\circ} \mathrm{C}$, and precipitation ranging from 700 to $1000 \mathrm{~mm} /$ year, and a dry season from November to mid-May, with an average minimum daily temperature of $30{ }^{\circ} \mathrm{C}$, an average maximum daily temperature of $40^{\circ} \mathrm{C}$ and hardly any precipitation (Billand et al., 2005). During the first part of the dry season, from November to February, a dry dusty wind blows through the North of Benin, also referred to as harmattan, which boosts the drying process of natural pasture. The harmattan facilitates burning of dried pasture, either from prescribed early fires used to reduce fuel accumulation or from late bush fires.

In Benin, the WBR is bordered by five districts, with the main economic activities being crop farming and livestock production. The WBR and its surrounding land are located in the so-called agro-pastoral contact zone in West Africa (De Haan et al., 1990), indicating that land is suitable for crop farming and livestock farming, enabling competition for land (Tamou et al., 2016a). Crop farmers get their main income from production of cereals (maize, sorghum, millet, rice), roots and tubers (yam, cassava, potato and sweet potato), legumes (groundnut, beans, soybean and bambara bean), vegetables (tomato, pepper, okra, pumpkin) and cotton, and possess oxen for ploughing. They belong to the following ethnic groups: Baatonu, Dendi, Monkole and Goumantche. In contrast, pastoralists obtain their main income from livestock and livestock products, and belong to the Fulbe ethnic group. The Fulbe pastoralists are dwellers of the districts surrounding the WBR and some of them come from the bordering countries Burkina Faso, Niger and Nigeria, during the dry season (Tamou, 2002) .

The research was conducted in the periphery of the Park, comprising three agroecological zones: the Sahelo-Sudanian zone in the north, the Sudanian zone in the south and an intermediate zone in between the north and south regions. Average 
rainfall ranged from $700 \mathrm{~mm} /$ year in the north to $1000 \mathrm{~mm} /$ year in the south. Selection of the three agro-ecological zones was done to cover possible variation of pastoralists' knowledge about indigenous cattle breeds and their traits. One village and two adjacent hamlets were selected in each agro-ecological zone. Selection of villages was done according to following criteria: i) being representative of the zone (in terms of climatic conditions and land uses), ii) being close to the edge of the WBR Park, and iii) representing ethnic diversity in the area (i.e. co-existence of Fulbe community and other ethnic groups). The first author was introduced to Fulbe pastoralists' leaders by employees of the livestock service (of the Ministry of Agriculture) in each of the villages and hamlets. Research objectives and methodologies were discussed with these pastoralists' leaders and their permission to conduct the study was obtained.

\subsubsection{Data collection}

Data were collected between November 2014 and April 2015. Information was derived from three sources: rapid appraisals, focus group discussions (FGD), and individual interviews (Figure 1).

\subsubsection{Rapid appraisals}

Informal interviews about indigenous cattle breeds kept by Fulbe pastoralists were held with five employees of the veterinary services working in the periphery of the WBR. The first author also collected information from rapid appraisals (Chambers, 1994) during field visits to the nine communities selected for data collection. On the basis of these rapid appraisals, the first author prepared input for the FGDs.

\subsubsection{Focus group discussions}

FGDs were held in each of the nine selected communities. The number of participants ranged from 15 to 20 people per FGD. Participants were all men, and most of the time elders, who were members of the village and hamlet council. The objective of the FGDs were: to introduce the study, to engage pastoralists' participation in the study design, and to have a FGD (McLafferty, 2004) about the cattle breeds used in herding and the traits they considered relevant. In addition, the FGDs were used to develop a semi-structured questionnaire for the individual interviews and to select relevant age classes to study the generation effect on traditional knowledge of cattle breeds and their traits. The first author facilitated the 
Roles and functions of cattle breeds for pastoralists

discussions in French and was translated into the local language (i.e. Fulfulde) by a trained interpreter. The FGDs lasted from 1 to 1.5 hours and were audio-recorded. The analysis of the FGDs (methodology described in section Data analysis) enabled the selection of the dimensions (described hereunder) and items within dimensions to be further discussed in the individual interviews. Selected dimensions and items were discussed and selected together with pastoralists' representatives.

a) Relevant age classes for assessing traditional knowledge about herding.

During FGDs, pastoralists agreed that three generations were of relevance (between brackets their Fulfulde name) to study the traditional knowledge of pastoralists in herding: the young (Alwasibey) generation (18-30 years old), the mid (Dotibey) generation (40-60 years old) and the old (Nahebey) generation (> 6o years old).

\section{b) Dimensions and items for the individual interviews}

b1) Inventory of cattle breeds. The participants of the FGDs were asked to make a list of cattle breeds found in their area. We used the names given by pastoralists to the indigenous breeds in their own Fulfulde language.

b2) Inventory of traits of cattle breeds. Participants of the FGDs were asked to make a list of relevant traits of cattle breeds. Then, participants were asked to select the four most relevant traits.

b3) Preference for cattle breed and traits, and herd composition. Participants discussed their preferred cattle breeds and the reasons for this preference, as well as their preferred herd composition (single breed or multiple breeds) and the reasons for this.

\subsubsection{Individual interviews}

Based on the outcomes of the FGDs, we developed a semi-structured questionnaire with four sections. The first section addressed the profile of the interviewee (e.g. age or experience in herding) and the dominant cattle breed in the herd owned. A breed was considered dominant in a herd when more than $75 \%$ of the herd was composed of this breed. In the second section, interviewees were asked to assess the five most important cattle breeds. Cattle breeds were assessed based on the performance of four traits using a three-point scale (low, medium or high). In the third section, interviewees were asked to choose their preferred cattle breed and the reasons for 
this preference, as well their preferred herd composition (i.e. single breed or multiple breeds herd) and the associated reasons.

Individual interviews were conducted face to face. In total, 72 interviews were conducted, being 24 interviewees (eight per age class) from each agro-ecological zone. The approach to potential individual interviewees started with participants of the FGDs, and followed by using the snowball technique, i.e. each participant suggested two or three new potential participants. The inclusion criterion for the interview was to have experience in herding and hence, be knowledgeable about cattle breeds. Interviewees participated on a voluntary basis and the interview took place in the interviewee's household. Individual interviews lasted between 45 minutes and one hour. The first author asked the questions in French and the questions were then translated into the local language by a trained interpreter.

\subsubsection{Data analysis}

Data analysis consisted of a descriptive analysis of information obtained from FGDs and a statistical analysis of data obtained from the individual interviews (Figure 1).

\subsubsection{Focus group discussions}

The FGDs were analysed following content analysis (Stewart and Shamdasani, 2014). The first author summarised the discussions and categorised general patterns (Pope and Mays, 1995) into dimensions and items within dimensions (Elo and Kyngäs, 2008). A mixed inductive and deductive approach (Bernués et al., 2016) was followed to select the dimensions (i.e. cattle breeds, traits and preferences) and items within dimensions (i.e. the particular breeds, traits and reasoning) to be further discussed in the individual interviews.

\subsubsection{Analysis of data of individual interviews}

We combined Chi-square test and Pearson's standardised residuals to analyse pastoralists' perception of their breeds. Within each trait, we first used the chi-square test to check for significant association between the number of interviewees and the score. We then calculated Pearson's standardised residual, which is the deviation of the observed number of interviewees for a given score from its expected value (Agresti, 2007). Pearson's residuals of more than +3 and lower than -3 were considered significant (Agresti, 2007), i.e. indicating that there was a high level of 
Roles and functions of cattle breeds for pastoralists

agreement among pastoralists. The Pearson's standardised residual was calculated as follows:

Residual $=(O-E) / \sqrt{E}$

Where $O$ is the observed number of interviewees, and $E$ is the expected number of interviewees (Agresti, 2007).

We used the 72 individual interviews to determine the dominant cattle breeds in the region, the performance of these breeds, the preference and reasoning for a particular breed, and the preferred herd composition and the associated reasons.

We used Fisher's exact test (because of the small sample size) and a post-hoc analysis based on pairwise comparison (Mangiafico, 2016) to test for association between generation and agro-ecological zone with regard to i) preference for cattle breeds, ii) perception of cattle breeds' performance on selected traits, and iii) preference for herd composition. All statistical analyses were done in R 3.3.2 (R Core Team, 2016).

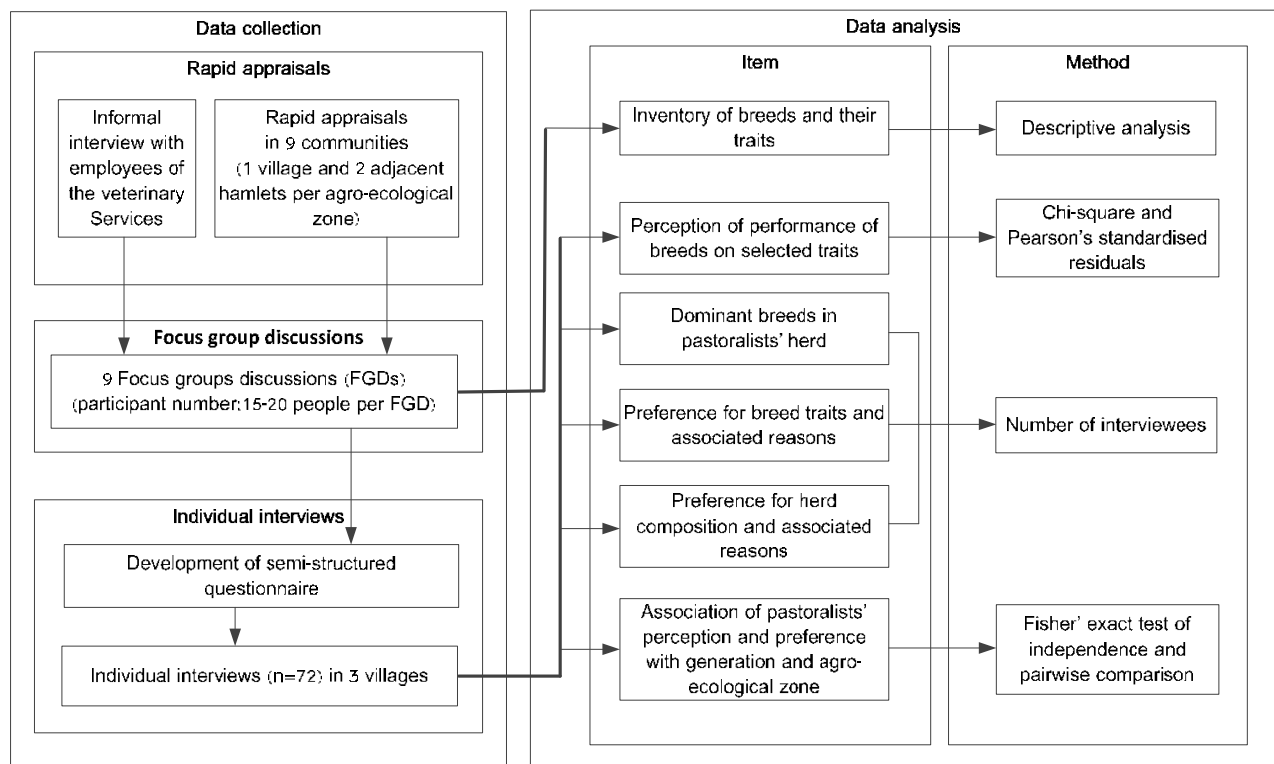

Figure 1. Framework of data collection and analysis (adapted from Oteros Rozas et al. (2013))

\subsection{Results}

\subsubsection{Inventory of breeds and their traits}

Participants of the FGDs mentioned the following cattle breeds to be present in the study area: Gudali, Keteeji, Jaliji, Bodeji, Tchiwali, and Ajawaji. The Ajawaji breed 
was excluded because pastoralists reported that was scant in their herds. They knew it was well established in Niger republic. Table 1 presents characteristics of selected cattle breeds. Keteeji is a Bos taurus (humpless), whereas the other breeds belong to Bos indicus (zebu, humped) (Felius, 1995). Keteeji belongs to the group of recently derived breeds, which is now a stabilized crossbred, between a humpless shorthorn with zebu (Felius, 1995). Among these breeds, Gudali was the (almost) hornless one.

Participants of the FGDs mentioned the following traits to be of importance when valuing a cattle breed: milk production, meat production, withstanding long walk, tolerance to trypanosomiasis, withstanding hunger (capacity to survive with feed shortage), withstanding thirst, intelligence of the breed, obedience to herder, short calving interval, and beauty of the coat (aesthetic trait). From this list, FDGs selected the following traits as being the most relevant for a cattle breed: milk production (hereafter referred to as milk), meat production (hereafter referred to as meat), withstanding long walk (hereafter referred to as endurance) and tolerance to trypanosomiasis (hereafter referred to as trypanotolerance). FGDs mentioned that milk and meat are the main sources of protein and income in their household. Hence, these traits were considered of utmost importance when assessing cattle breeds. Endurance was also considered of importance, because grazing areas are far

Table 1. Characteristics of breeds present in the W Biosphere Reserve in Benin

\begin{tabular}{|c|c|c|c|c|c|}
\hline \multirow[b]{2}{*}{ characteristics } & \multicolumn{5}{|c|}{ indigenous breeds } \\
\hline & Keteeji & Jaliji & Bodeeji & Tchiwali & Gudali \\
\hline type of horn & shorthorn & shorthorn & longhorn & longhorn & $\begin{array}{l}\text { Almost } \\
\text { hornless }\end{array}$ \\
\hline $\begin{array}{l}\text { average weight } \\
\text { (male-female, } \mathrm{kg} \text { ) }\end{array}$ & $260-226$ & $300-300$ & $425-275$ & $500-323$ & $525-325$ \\
\hline $\begin{array}{l}\text { average milk production } \\
\text { (L/day) }\end{array}$ & 2.5 & 2.0 & $5 \cdot 5$ & $5 \cdot 5$ & $7 \cdot 5$ \\
\hline breed group & taurine & zebu & zebu & zebu & zebu \\
\hline coat colour & not specific & $\begin{array}{l}\text { not } \\
\text { specific }\end{array}$ & red & white & $\begin{array}{l}\text { not } \\
\text { specific }\end{array}$ \\
\hline $\begin{array}{l}\text { country of dominance } \\
\text { (West Africa) }\end{array}$ & $\begin{array}{l}\text { Benin, } \\
\text { Nigeria, }\end{array}$ & $\begin{array}{l}\text { Niger, } \\
\text { Burkina } \\
\text { Faso }\end{array}$ & $\begin{array}{l}\text { Niger, } \\
\text { Nigeria }\end{array}$ & $\begin{array}{l}\text { Niger, } \\
\text { Nigeria }\end{array}$ & $\begin{array}{l}\text { Niger, } \\
\text { Nigeria }\end{array}$ \\
\hline synonym & $\begin{array}{l}\text { Borgu, } \\
\text { Keteku, }\end{array}$ & $\begin{array}{l}\text { Jali, } \\
\text { Jelli }\end{array}$ & $\begin{array}{l}\text { M'Bororo, } \\
\text { Red Fulani }\end{array}$ & $\begin{array}{l}\text { White } \\
\text { Fulani, } \\
\text { Daneji }\end{array}$ & $\begin{array}{l}\text { Sokoto, } \\
\text { Godali }\end{array}$ \\
\hline
\end{tabular}


Roles and functions of cattle breeds for pastoralists

away from pastoralists' villages and livestock have to walk long distances in search for forages. Trypanotolerance was also considered important because good forages are generally found in humid areas where the tsetse fly is found. Therefore, trypanotolerant cattle are an asset to overcome possible contagion of the herd. Acute trypanosomiasis disease is characterised by decreased productivity, weight loss, abortion and possibly death. Animals that survive usually show low productivity and infertility.

\subsubsection{Performance of breeds on selected traits}

Table 2 presents the performance of each cattle breed in four traits as perceived by pastoralists. Pastoralists perceived Keteeji of low value for milk, of medium value for meat, and of high value for trypanotolerance. Jaliji was of medium value for meat and for endurance. Pastoralists had scattered perception of Tchiwali. Bodeeji was of high value for meat and for endurance. Gudali was perceived of high value for milk and for meat, but of low value for endurance.

Table 2. Performance of cattle breeds in four traits as perceived by pastoralists (number of interviewees scoring in performance)

\begin{tabular}{|c|c|c|c|c|c|c|}
\hline \multirow[b]{2}{*}{ breed traits } & \multirow[b]{2}{*}{ performance } & \multicolumn{5}{|l|}{ breed } \\
\hline & & Keteeji & Jaliji & Tchiwali & Bodeeji & Gudali \\
\hline \multirow[t]{3}{*}{ milk } & high & $19^{\beta}$ & 33 & 31 & 55 & $67^{a}$ \\
\hline & medium & 33 & 29 & 32 & 13 & $5^{\beta}$ \\
\hline & low & $20^{\alpha}$ & 10 & 9 & 4 & $\mathrm{O}$ \\
\hline \multirow[t]{3}{*}{ meat } & high & $21^{\beta}$ & $21^{\beta}$ & 42 & $62^{a}$ & $67^{\alpha}$ \\
\hline & medium & $39^{\alpha}$ & $42^{a}$ & 28 & $8^{\beta}$ & 5 \\
\hline & low & 12 & 9 & 2 & 2 & o \\
\hline \multirow[t]{3}{*}{ endurance } & high & 12 & 13 & 28 & $66^{a}$ & $3^{\beta}$ \\
\hline & medium & 36 & $41^{\alpha}$ & 38 & $4^{\beta}$ & $7^{\beta}$ \\
\hline & low & 24 & 18 & $6^{\beta}$ & $2^{\beta}$ & $62^{\alpha}$ \\
\hline \multirow[t]{3}{*}{ trypanotolerance } & high & $35^{\alpha}$ & 9 & 19 & 5 & 9 \\
\hline & medium & 16 & 19 & 29 & 11 & 12 \\
\hline & low & 21 & 44 & 24 & 56 & 51 \\
\hline
\end{tabular}

\subsubsection{Dominant cattle breeds mentioned by pastoralists}

Figure 2 presents the breed dominant in the herds of the pastoralists interviewed. Keteeji was the most dominant breed (74\%), followed by Jaliji (17\%), Tchiwali (6\%) and Bodeeji (3\%). None of the pastoralist mentioned having a herd with the Gudali 


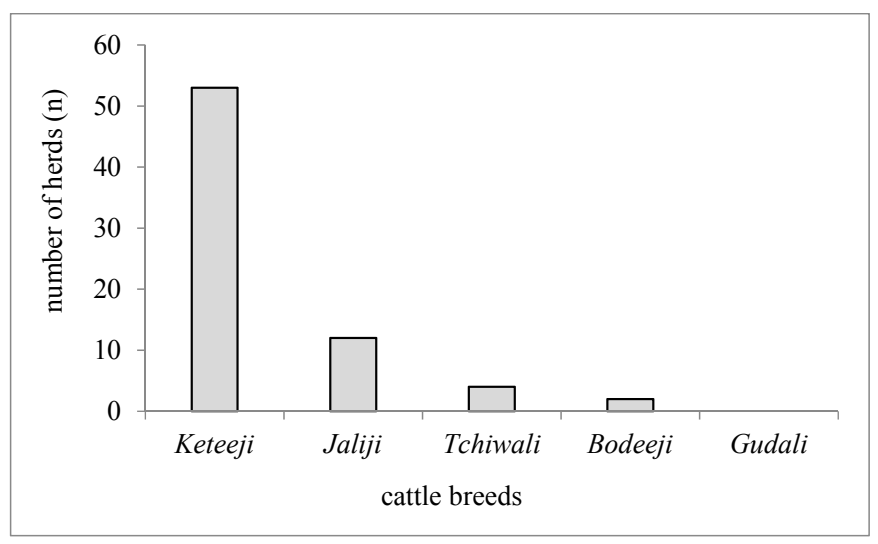

Figure 2. Number of herds in which the cattle breed is dominant ( $>75 \%$ of the herd of a particular cattle breed)

breed as the dominant breed. During fieldwork, some Gudali cattle in the herds of some interviewees was observed, indicating that Gudali is indeed kept, but in low numbers.

\subsubsection{Preference for breed and associated reasons}

Table 3 presents the stated preference of pastoralists for a particular cattle breed and the associated reason for this preference. Keteeji was the most preferred breed (nearly 50\% of the respondents preferred this breed). The most mentioned reason to prefer Keteeji was the capability of the breed to withstand hunger $(83 \%$ of the respondents that preferred Keteeji breed). The other breeds were less preferred, Gudali (11\%) and Jaliji (7\%) being the least mentioned by pastoralists.

Table 3. Pastoralists' preference for cattle breeds and the associated reasons $(n=72)$

\begin{tabular}{|c|c|c|c|c|c|c|c|c|}
\hline \multirow[b]{2}{*}{ breeds } & \multicolumn{8}{|c|}{ reasons for breed preference } \\
\hline & $\begin{array}{l}\text { withstanding } \\
\text { hunger }\end{array}$ & $\begin{array}{l}\text { intelligent } \\
\text { breed }\end{array}$ & $\begin{array}{l}\text { productivity } \\
\text { (milk and } \\
\text { meat) }\end{array}$ & $\begin{array}{l}\text { experience } \\
\text { with breed }\end{array}$ & $\begin{array}{l}\text { withstanding } \\
\text { diseases }\end{array}$ & $\begin{array}{c}\text { short } \\
\text { calving } \\
\text { interval }\end{array}$ & charm & $\begin{array}{c}\text { total } \\
\text { count per } \\
\text { breed }\end{array}$ \\
\hline Keteeji & 29 & - & - & 4 & 2 & - & - & 35 \\
\hline Jaliji & 3 & - & - & - & 2 & - & - & 5 \\
\hline Tchiwali & 4 & 1 & - & - & 3 & 5 & 1 & 14 \\
\hline Bodeeji & - & 8 & 2 & - & - & - & - & 10 \\
\hline Gudali & - & - & 7 & - & 1 & - & - & 8 \\
\hline $\begin{array}{l}\text { total count } \\
\text { per reason }\end{array}$ & 36 & 9 & 9 & 4 & 8 & 5 & 1 & 72 \\
\hline
\end{tabular}


Roles and functions of cattle breeds for pastoralists

Among the reasons to prefer a cattle breed, withstanding hunger was the most mentioned reason (50\% of the respondents selected a breed based on this reason). Surprisingly, pastoralists did not mention one of the four traits as main reason for breed preference.

\section{5•3.5 Preference for herd type and associated reasons}

Keeping one single breed in a herd was the most preferred herd type (61 out of 72 interviewees), because of two reasons: one single breed implies one requirement (35 out of 61 interviewees) in terms of feeding, watering frequency and disease management; and herding one single breed results in better herd behaviour (26 out of 61 interviewees). The latter means that the overall herd is prone to follow the leading-cow, making the herd more compact, facilitating the management and reducing the number of scattered and strayed cows. For pastoralists preferring multiple breeds per herd, the reason was to have breed diversity, which means less risk in the event of disease or drought (resilience), and a diversity in milk taste.

\subsubsection{Perception and preferences across generations and agro-ecological zones}

Table 4 presents the generation effect on perception of the performance of the breeds in traits studied. In general, breed traits were perceived similarly across generations. Only the perceived value of Bodeeji's traits differed across generations. Young

Table 4. Effect of generation (young, mid and old) on pastoralists' perception of breeds' performance in traits milk, meat, endurance and tyrypanotolerance

\begin{tabular}{|c|c|c|c|c|c|c|}
\hline \multirow[b]{2}{*}{ breed trait } & \multirow[b]{2}{*}{ performance } & \multicolumn{5}{|l|}{ breed } \\
\hline & & Keteeji & Jaliji & Bodeeji & Tchiwali & Gudali \\
\hline milk & $\begin{array}{l}\text { high } \\
\text { medium } \\
\text { low }\end{array}$ & ns & ns & $\begin{array}{l}\text { mid \& old } \\
\text { young }\end{array}$ & $\mathrm{ns}$ & ns \\
\hline meat & $\begin{array}{l}\text { high } \\
\text { medium } \\
\text { low }\end{array}$ & ns & ns & $\begin{array}{l}\text { mid \& old } \\
\text { young }\end{array}$ & $\mathrm{ns}$ & ns \\
\hline endurance & $\begin{array}{l}\text { high } \\
\text { medium } \\
\text { low }\end{array}$ & ns & ns & $\mathrm{ns}$ & $\mathrm{ns}$ & ns \\
\hline trypanotolerance & $\begin{array}{l}\text { high } \\
\text { medium } \\
\text { low }\end{array}$ & ns & ns & $\begin{array}{l}\text { young } \\
\text { mid \& old }\end{array}$ & $\mathrm{ns}$ & ns \\
\hline
\end{tabular}

If generation effect is significant, then it is indicated in which performance class the majority of the generation scored. ns: not significant $(\mathrm{P}>0.05)$, indicates no generation effect 
pastoralists perceived the breed to score medium for milk, meat and trypanotolerance, whereas the mid and old generations perceived the breed as high in milk and meat production, and low trypanotolerance. Preferences of pastoralists for type of breed and herd composition did not differ across generations ( $\mathrm{P}>\mathrm{O} .05$, not in table).

Table 5 presents the agro-ecological zone effect on perception of performance of breeds in traits studied. In general, pastoralists from the different agro-ecological zones perceived the breeds to perform similarly. However, the perceived performances of Keteejïs and Tchiwali's traits differed across agro-ecological zones. In general, pastoralists living in the south perceived the two breeds to score high, whereas those living in the mid and north zones gave scores of low to medium value for the same traits.

The preference of pastoralists for the type of breed differed across agro-ecological zones $(\mathrm{P}<0.01$, not in table). Keteeji was preferred in the south and mid agroecological zones whereas Bodeeji was preferred in the north. The preference of pastoralists for herd composition did not differ across agro-ecological zones $(\mathrm{P}>\mathrm{O} .05$, not in table).

Table 5. Effect of agro-ecological zone (south, mid and north) on pastoralists' perception of breed performance in traits milk, meat, endurance and trypanotolerance

\begin{tabular}{|c|c|c|c|c|c|c|}
\hline \multirow[b]{2}{*}{ breed trait } & \multirow[b]{2}{*}{ performance } & \multicolumn{5}{|l|}{ Breed } \\
\hline & & Keteeji & Jaliji & Bodeeji & Tchiwali & Gudali \\
\hline$\overline{\text { milk }}$ & $\begin{array}{l}\text { high } \\
\text { medium } \\
\text { low }\end{array}$ & $\begin{array}{l}\text { south } \\
\text { mid } \\
\text { north }\end{array}$ & $\mathrm{ns}$ & $\mathrm{ns}$ & $\begin{array}{l}\text { south } \\
\text { mid } \\
\text { north }\end{array}$ & ns \\
\hline meat & $\begin{array}{l}\text { high } \\
\text { medium } \\
\text { low }\end{array}$ & $\begin{array}{l}\text { south } \\
\text { mid \& north }\end{array}$ & ns & $\mathrm{ns}$ & $\begin{array}{l}\text { south } \\
\text { mid \& north }\end{array}$ & ns \\
\hline endurance to walk & $\begin{array}{l}\text { high } \\
\text { medium } \\
\text { low }\end{array}$ & $\mathrm{ns}$ & $\mathrm{ns}$ & $\mathrm{ns}$ & $\begin{array}{l}\text { south } \\
\text { mid \& north }\end{array}$ & $\begin{array}{l}\text { south } \\
\text { mid \& north }\end{array}$ \\
\hline trypanotolerance & $\begin{array}{l}\text { high } \\
\text { medium } \\
\text { low }\end{array}$ & $\begin{array}{l}\text { north } \\
\text { south \& mid }\end{array}$ & $\mathrm{ns}$ & ns & ns & ns \\
\hline
\end{tabular}

If effect of agro-ecological zone is significant, then it is indicated in which performance class the majority of the generation scored.

ns: not significant $(\mathrm{P}>0.05)$, indicates no generation effect 
Roles and functions of cattle breeds for pastoralists

\subsection{Discussion}

This study aims at understanding knowledge of pastoralists about indigenous cattle breeds, their preference for specific breeds and associated reasons. We found that pastoralists had a common knowledge about their cattle breeds, regardless of the generation and the agro-ecological zones (except for some minor differences). The fact that the knowledge was common across generations was surprising to us. An increased body of literature describes the loss of traditional ecological knowledge (TEK) due to direct threats (Tang and Gavin, 2016). In the area of study, we identified some of the most common threats eroding TEK, such as limited access or loss of traditional land wherein to develop the land-based activities (i.e. grazing), change of environment and natural resources, changes in traditional livelihood practices, or lack of institutional support to traditional rights and traditional institutions (Tamou et al., 2016a). In this case, the maintenance of TEK across generations could be explained by the absence of other well documented threats, such as loss of pathways of TEK transmission (e.g. loss of traditional language, influence by formal education system, absence of younger generations from the traditional community or influence by dominant societies), change of traditional religion or beliefs, or shift to westernised production systems with reliance on modern products and technologies (Tang and Gavin, 2016). Fulbe are a proud traditional community of pastoralists (Bierschenk, 1995). In the area of study, we found a traditional involvement of Fulbe pastoralists into herding activities from early ages (Tamou et al., 2016b), low schooling rates of young pastoralists and lack of opportunities outside the herding activities (except cropping). Therefore, young men are taught by their parents and as exposed to knowledge about herding and breed traits as their parents are. Hence, the transmission of TEK in this area did not show signs of erosion.

Pastoralists' knowledge about indigenous cattle breeds was consistent with scientific literature. For instance, Gudali is well known for having a high beef performance (Felius, 1995); Bodeeji is described to perform well in endurance and to be intelligent (Ayantunde et al., 2007); and Keteeji is tolerant to trypanosomiasis (Blench, 1999) and it endures under harsh environmental conditions (Rege et al., 1994; Shabtay, 2015) with shortage of forage. We also found that pastoralists generally agreed on Bodeeji performing well in milk production, which is similar to pastoralists' 
perception about this breed in southern Niger (Ayantunde et al., 2007). This reflects that pastoralists had a perception of the breeds and their performances, based on TEK, and this in line with that reported in scientific literature.

Our findings demonstrate that pastoralists consider productive traits and especially non-productive traits as important. First, during the FGDs, 2 productive (i.e. meat and milk) and 2 non-productive traits (i.e. endurance and trypanotolerance) were selected as the most relevant traits in cattle breeds. Second, when exploring preferences for a breed and the reasoning for this preference, $80 \%$ of pastoralists selected a breed based on a non-productive trait. In this case, traits that enable adaptation to the environment prevailed, such as withstanding hunger for Keteeji, intelligence for Bodeeji or withstanding disease for several breeds. The preference for adaptive traits can possibly be attributed to the changes in the pastoral environment occurring in the area of study (Tamou et al., 2016a). In the periphery of the WBR, the encroachment of arable land at the expense of natural and semi-natural areas is resulting in a loss and fragmentation of grazing areas and watering points (Avakoudjo et al., 2014; Clerici et al., 2007; Houessou et al., 2013; Tamou et al., 2016a). Hence, preference for breeds that withstand hunger or with high endurance to walk in search for forage may reflect strategies to cope with shortage of pasture and watering points (Liao et al., 2016).

The scarcity of grazing lands has also pushed pastoralists to graze illegally inside the WBR (Tamou et al., 2016a) or to look for pastures where trypanosomiasis may be a risk. Pastoralists in the north zone preferred Bodeeji because of its intelligence to the herder, which is important when grazing illegally inside the WBR. According to those pastoralists, Bodeeji herds can be instructed to run away when discovered by patrollers of the WBR authority and then meet at their compound, avoiding the herder to be arrested and fined. Preferences for adaptive traits among pastoralists is in line with Dossa et al. (2007) for goat keeping in southern Benin and with Ayantunde et al. (2007) for cattle in southern Niger. This finding suggests that pastoralists might change their preference for the adaptive traits in case of change of their environment. In the current situation of conversion of grazing land into crop land in the study area, adaptive traits for endurance are preferred. However, the incipient shift in lifestyle suggested by (Tamou et al., 2016a), in which pastoralists have initiated crop farming, and the claim for more land (to graze and cultivate) may 
Roles and functions of cattle breeds for pastoralists

lead to change in the preferred breeds and traits, as well as in the roles and functions of livestock.

Besides preference for breeds based on non-production traits, our findings show that the majority of pastoralists preferred keeping a single breed in their herd. The diversity of breeds was not perceived as an asset of resilience in this changing environment. In contrast, herds with diverse breeds were perceived as more demanding in terms of feeding and disease management. Therefore, from a pastoralists' perspective, cattle diversity within a herd was less desirable. This finding contradicts the fact that while oriented towards minimizing risk, pastoralists are prompt for conserving diversity (Mathias et al., 2005). Conserving diversity by pastoralists is adopted only when it is in line with their livestock keeping objectives.

\subsection{Implications for policy on management of livestock diversity}

In this study, we found that pastoralists are knowledgeable about traits of their reared breeds. TEK is a reservoir of knowledge that can guide scientists. Pastoralists valued the adaptive traits of their livestock more than productive traits. This suggests that improvement of indigenous breeds by targeting high productivity might not be aligned with pastoralists' preferences and needs. Moreover, maintaining and improving indigenous breeds of cattle should be accompanied with a range of actions supported by governmental institutions, such as ensuring access to grazing lands and hence, access to feed resources, supporting traditional livelihoods practices and recognizing traditional rights and institutions. Therefore, policies should set appropriate objectives compatible with the production system, rather than ambitious performance objectives incompatible with prevailing conditions (FAO, 2015).

The continued loss of pastoral land and resources, and the pressure on pastoral communities, may be steering the preferences of pastoralists into cattle with high adaptive traits. Preferences for particular breeds and keeping a single breed herd are potential threats to cattle diversity in the area under study. This implies that national policies should also consider conserving less desired breeds. Conservation of a variety of local breeds in pastoral communities could assist in addressing the high projected demand for animal food products (Delgado et al., 2001) in and around the studied area, as well as challenges of emerging diseases and new consumers' 
preference. To this end, in vivo conservation should be encouraged as framed in the community-based conservation of AnGR (Köhler-Rollefson, 2003). In addition, ex situ conservation or cryopreservation could also be implemented at international level as the investigated breeds are transboundary.

\subsection{Conclusion}

This study aims at understanding pastoralists' knowledge about indigenous cattle breeds and their preference for specific breeds and the associated reasons. We found that pastoralists had common knowledge about traits of the indigenous breeds, regardless of the effect of generations. Pastoralists valued more the adaptive traits than the productive traits. Preference for such traits is a strategy to cope with the shortage of pasture in the study area. In the current situation, with an unfavourable environment for pastoralists, preference for such breeds and preference for keeping a single breed in the herd might be a potential threat for indigenous cattle diversity. This can compromise future improvement of breeds or adaptation of the farming systems in a region under change. There is, therefore, a need to also conserve the less desired breeds.

\section{Acknowledgements}

The research was funded by the Netherlands organisation for international cooperation in higher education (NUFFIC) under the grant NFP-PhD 322/2012 and the Animal Production Systems group of Wageningen University \& Research. The first author would like to thank Fokje Steenstra for assistance with the statistical analyses and Akke Kok for providing comments on an early version of this manuscript. 


\section{Chapter 6}

\section{General discussion}

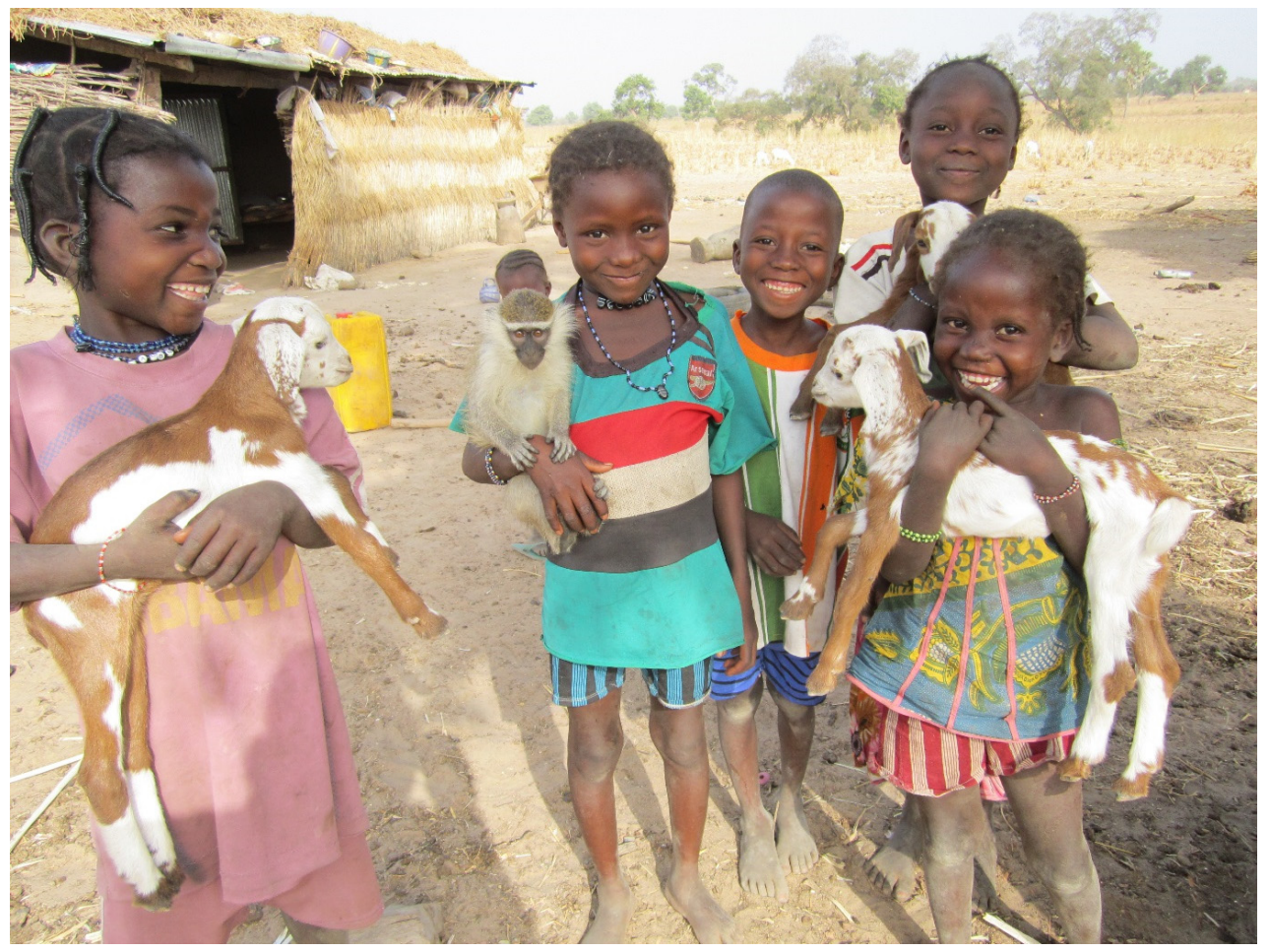

Children of Loumbou-Loumbou village holding a monkey and goats 


\subsection{Introduction}

The competition for land has become an issue of major concern and cause of conflict (De Haan, 2016; Young et al., 2016), especially between pastoralists and crop farmers (Fratkin and Mearns, 2003; Turner, 1999; Young et al., 2016), but also between pastoralists and nature conservation institutions (Convers et al., 2007; Reid et al., 2004; Toutain et al., 2004). The Biosphere Reserve of $W$ in Benin Republic (WBR) and its surrounding land are located in the agro-pastoral contact zone in West Africa (De Haan et al., 1990), implying that land is suitable for crop farming and pastoralism, potentially enabling competition for land. In, and especially in the periphery of the WBR, natural vegetation (grazing land) is being converted into cropland (Avakoudjo et al., 2014; Clerici et al., 2007; Houessou et al., 2013). This not only implies a loss of grazing land with a specific biodiversity value, but it may also change the pastoral system. Changes in the pastoral system may lead to loss of pastoralists' traditional ecological knowledge (TEK). In addition it may compromise pastoralists' contribution to maintaining indigenous livestock diversity. To maintain the socio-economic and environmental benefits of pastoralism, it is important to understand pastoralists and their relations with their changing environment.

The general aim of this thesis, therefore, was to understand the relations between pastoralism and its changing natural environment. The first step towards understanding these relations is to understand drivers of land use change and competition for land in and around the WBR. The aim of chapter 2, therefore, was to describe and analyse i) land use changes in order to understand their drivers, and ii) the viewpoints of relevant stakeholders in order to understand the competition for land in and around the WBR. In chapter 3 , I evaluated the effect of grazing intensity in and around the WBR on i) plant community diversity in the aboveground vegetation, ii) seed abundance and species diversity in the soil seed bank, and iii) similarity of species prevalence between aboveground vegetation and soil seed bank. The next aim was to get insights into how pastoralists use natural resources. Chapter 4, therefore, had the following objectives: i) to inventorise and assess how pastoralists characterise and value soils and forages in their environment, ii) to analyse how soil, forage and livestock characteristics relate to herding decisions, and iii) to determine whether TEK underlying herding decisions differs across generations. Finally, to understand pastoralists' perception of their indigenous 
General Discussion

breeds and their associated desired traits, the objectives of chapter 5 were: i) to inventorise indigenous breeds of cattle and their traits, ii) to analyse pastoralists' preference for breeds and associated reasons, and iii) to determine whether knowledge about breed traits differs across generations.

In the next sections, I, first, present the main findings and implications of these abovementioned chapters. Second, in light of the implications of these findings and of previous studies, I then discuss the future of pastoralism.

\subsection{Main findings and their implications}

\subsubsection{Competition for lands}

In chapter 2, results show that in and around the WBR cropland expanded at the expense of pastoral land. Drivers of such expansion were population growth, which caused an increase in settling of new farming households. Farming households settled partly on inherited cropland, but also on new crop fields cleared on grazing lands. Besides population growth, crop expansion was triggered also by economic reasons, namely the increasing options for selling of food and cash crops. The demand for food crops increased in response to the increasing demand for food in urban regions in Benin and in the bordering countries Nigeria (the most populated country in Africa) and Niger (an arid country with instability in crop production). The cash crop cotton accounts for nearly 40\% of Benin's gross domestic product and for roughly $80 \%$ of the official export receipt. The development in the cotton sector due to state incentives such as subsidised fertilisers has increased the area dedicated to cotton cultivation at the expense of grazing lands. The customary land rights did not favour pastoralists, as it does not consider grazing as an occupation of land. Therefore, land ownership was denied to pastoralists. Competition for land between crop farmers and pastoralists occurred not only outside the WBR, but also in the buffer zone which is under regulation of the WBR authority. In addition, crop farmers and pastoralists were also claiming lands inside the WBR, with diverse arguments such as expropriation and unfair implementation of the regulations of the whole WBR.

The main implication of chapter 2 is that, in this competition for lands, pastoralists are becoming marginalised, because they are losing their grazing lands. Without any 
Chapter 6

change, this marginalisation will continue, and this will likely increase pastoralists' vulnerability, with related consequences.

\subsubsection{Positive effect of pastoralism on diversity of plant communities}

The main finding of chapter 3 is that around the WBR plant diversity increased with higher grazing intensity, in the aboveground vegetation and in the soil seed banks. This finding is not in line with the perception that nature conservationists and policy-makers commonly have about grazing. In general, they believe that grazing leads to overgrazing and finally to rangeland degradation, in line with the theory of the "tragedy of the commons" (Hardin, 1968). My study shows, however, that pastoralism is not always harmful to biodiversity, suggesting that it can co-exist with nature conservation. Results also show that annual grasses dominated the vegetation in sites with high, but also in sites with low grazing intensity, suggesting a replacement of perennial grasses even under limited grazing (Hoffman and Todd, 2000; Houessou et al., 2012). Moreover, unpalatable plants such as forbs increased in highly grazed sites, indicating that grazing at whatever level induces changes of species composition compared to that of ungrazed vegetation. The question remains whether this increase of forbs should be considered as a sign of grassland degradation. The field observation indicates that land cover by the vegetation is still good in and around the WBR.

In summary, results of chapter 3 suggest that, under certain conditions, pastoralism can co-exist with nature conservation. In that case, there should be a compromise between the authentic species composition of ungrazed vegetation and the increased species diversity of a vegetation under grazing.

\subsubsection{Pastoralists' knowledge of rangeland use and livestock diversity}

This thesis improved our understanding of pastoralists' TEK underlying herding decisions (chapter 4) and pastoralists' knowledge about roles and functions of indigenous breeds of cattle (chapter 5 ).

Results described in chapter 4 show that pastoralists had extensive and detailed understanding of how soil, forage and livestock characteristics affect herding, and their herding decisions are based on the TEK developed and transmitted across generation. First, use of soils followed a calendar, and depended on the soil's wetness and the possible threat of livestock diseases. Second, pastoralists had a detailed 
General Discussion

knowledge about the nutritional quality of forages and even related such qualities to specific livestock production objective. Finally, pastoralists linked consumption of sufficient forages of good quality to their observations of livestock, i.e. the shininess of the coat and the way of breathing during resting. The relationship between these parameters and quality and quantity of forage intake is supported by scientific literature (Gaughan and Mader, 2014; Tresoldi et al., 2016). The TEK of pastoralists around the WBR is an example of TEK of indigenous communities to manage complex systems (Berkes et al., 2000). Pastoralists are aware of the conditions of the drylands' resources. Good herding is in the interest of pastoralists since it supports their subsistence, but it is also in the interest of the drylands since good herding avoids overgrazing. Pastoralists' TEK, therefore, is a reservoir of knowledge for the sustainable use of the drylands, i.e. producing food in such lands. In this sense, TEK is considered complementary to scientific knowledge by some authors (Berkes et al., 2000; Huntington, 2000), though in my study, the pastoralists' TEK could be explained by mechanisms reported by scientific literature.

Results of chapter 5 indicate that pastoralists had a common knowledge about indigenous breeds. For instance, pastoralists knew breeds that are resistant to important diseases and, at the same time, perform well with regard to endurance, i.e. standing a feed shortage. They also knew breeds with a high meat and milk production potential. Pastoralists valued the adaptive traits (i.e. endurance) more than the productive traits. Nevertheless, pastoralists maintain diverse breeds with diverse genetic traits. In developing countries cattle breeds are less well characterised and preserved than in developed countries (Hoffmann et al., 2011). Pastoralists' knowledge and their actual breeding of cattle are very important for the endeavour to preserve indigenous cattle breeds. Indigenous breeds are considered as buffer breeds against emerging diseases (since they may have genotypes that make them more resistant to such diseases) and they are a promising asset to respond to new consumer preferences (Oldenbroek, 1999). In this sense, the diversity of indigenous breeds and the knowledge associated with it are ecosystem services delivered by the pastoralists-dryland complex to humanity (CBD, 2010; Safriel and Adeel, 2005).

Chapters 4 and 5 show that, despite changes in the pastoralist system, pastoralists' TEK underlying herding decisions and about indigenous breeds were not lost across 
Chapter 6

generations. This could be explained by the observation that young pastoralists are actively involved in herding, still acquire knowledge through doing and being taught by the older generations, and there is little influence from outside the community. This implies that if young pastoralists are involved in herding, and external influences are limited, TEK will continue to exist and will be handed over to next generations of pastoralists.

Altogether, chapters 4 and 5 show that pastoralists maintain a good culture for sustainable use of the drylands, and they also contribute to livestock diversity.

\subsection{Methodology}

Some specificities of the study area need to be mentioned. The area under study is located in the transition zone between the Sudanian and the Sahelian zones of West Africa. Some scientists called it the agro-pastoral contact zone, referred to as a zone where crop farming and pastoralism can both take place. It is a semi-arid land and the findings of the study may apply to similar semi-arid areas, elsewhere in the world. However, findings of this study may not be applicable to more arid settings with different ecological and socio-economic conditions.

During focus group discussions and individual interviews, the researcher was sometimes considered as a civil servant, who can give solutions to their problems. Therefore, some pastoralists may have made statements to victimise themselves, so that the government favours them in solving the problem.

Livestock data in this study were for livestock that belonged to resident pastoralists, and they were obtained from statistics of the state vaccination campaigns. These data are likely underestimated. Vaccination data depend on the willingness of livestock keepers to present their herds for vaccination during the government vaccination campaigns. Most pastoralists will have their cattle vaccinated. However, some will do this through parallel (fraud) vaccination campaigns, organised by private veterinary services, out of the control of the state veterinary services. Hence, not registered and included in the state vaccination databases. I could not obtain information about total livestock numbers in the region from interviews and FGDs with pastoralists since they do not count their livestock out of socio-cultural reasons. 
General Discussion

Participants of individual interviews in chapters 2, 4 and 5 were selected using snowball sampling and based on their willingness to share their opinion. In doing so, the results of the interviews may have been affected by the snowball sampling effect, which is interviewing people that know each other, potentially with common opinions. The studies, therefore, may have missed possible valuable information from people outside the network of the first interviewee. The representativeness of the sample obtained through snowball sampling, therefore, may not be guaranteed (Biernacki and Waldorf, 1981).

In chapter 2, I combined remote sensing data, agricultural statistics and the perception of the main stakeholders to describe and analyse changes in land use over time. Data of agricultural statistics, provided by agricultural extension services are generally not considered accurate; the data about development of cotton production (being the most important and best organised agricultural activity in the country) are likely relatively more accurate than those about food crop production development. Remote sensing data of good quality were only available to me for few years. Nevertheless, the consistency between the three data sources indicates that the trends signalled are likely.

Interviews with pastoralists (chapter 2, 4 and 5) targeted the resident ones, living in the periphery of WBR. In doing so, I missed the viewpoints of the foreign pastoralists (from Niger and Nigeria) in the study area. I planned to have interviews with these foreign pastoralists (transhumant or nomadic), but I failed to meet them. Reasons for not meeting them are first, that such foreign pastoralists herd (illegally) inside the WBR, and they move fast to avoid being tracked by park authorities and second, pastoralists had bad experience with researchers in the study area, since pastoralists felt that researchers reported their presence inside the WBR to park authorities. So, I accepted that it was not possible to interview these foreign pastoralists. The mere reason that it was not possible to interview these foreign pastoralists is an indication that their situation is at least as marginalised as that of the settled pastoralists around the WBR; they live in a constant fear: fear of being arrested inside the WBR, fear for crop farmers who don't allow them on traditional grazing lands anymore and fear for being treated as "bushmen" and "dangerous people" with backward behaviour. 
Chapter 6

Vegetation of the study area is dominated by savannah which is characterised by high heterogeneity of habitats (Tongway and Ludwig, 2005). To account for such habitat heterogeneity, more than two levels of grazing intensity could have better reflected the actual dynamics of plant communities in response to grazing. It would be better, for instance, to include "non-grazed areas", "heavily grazed areas", or even "areas nearby crop-cultivated areas”. Moreover, data collected during many years are needed to make a strong conclusion about the observed pattern on species diversity in the WBR. Regarding the soil seed banks study, most of the annual species are dormant following seed dispersal, until a fire event breaks their dormancy. Soil seed bank samples were collected before fire events in the study area, because we needed to know species in the aboveground vegetation. This implies that more germinated seeds may be found if seeds have passed the fire events before their collection.

Nevertheless, findings of this study improve our understanding of the relations between pastoralism and its natural environment. Based on these findings, I discuss in the following sections the future of pastoralism in the study area, which is potentially applicable for other drylands.

\subsection{The future of pastoralism}

In summary, competition for land results in conflicts between pastoralists and crop farmers, and between pastoralists and nature conservation institutions. Pastoralists are perceived to be the problem, whereas in reality it may be crop farming, and its underlying drivers. Pastoralists are under pressure and prone to disappear, but if the latter would happen, human cultural heritage will get lost, together with the knowledge essential for sustainable management of drylands, including livestock diversity. In the following sections, I discuss different scenarios of the future of pastoralism, in light of the abovementioned findings and of literature related to pastoralism in the drylands. The first section describes livelihood strategies for pastoralists in the event that the current situation continues, and the two subsequent sections describe possible actions to maintain pastoralism.

\subsubsection{Livelihood strategies for pastoralists}

This study shows that pastoralists are struggling for their livelihoods in the periphery of the WBR. Livelihood is defined as the use of assets in activities to produce outputs, both to meet people's consumption requirements and aspirations and to invest in assets and activities for the future (Dorward et al., 2009). Dorward et al. (2009) 
General Discussion

described three pathways of livelihood strategies of smallholder farmers, which are also applicable to the pastoralists around the WBR: i) hanging-in, ii) stepping-up, and iii) stepping-out. In the "hanging-in" strategy, assets are held and activities are engaged in to maintain livelihood levels, often in the face of adverse socio-economic circumstances. In the "stepping-up" strategy, current activities are engaged in, with investments in assets to expand these activities, in order to increase production and income to improve livelihoods. In the "stepping-out" strategy, existing activities are engaged in to accumulate assets, which in time can then provide a base for moving into different activities that require initial investment.

In the study area, pastoralists are less favoured in terms of availability of land for grazing. Livestock mobility, which is essential to the pastoral system, therefore, is constrained. Since land for grazing is the dominant natural asset to pastoralism, it, therefore, is likely that pastoralists' strategy will depend on their current livestock holding. The poor pastoralists' strategy will be the hanging-in strategy, which is to continue their traditional pastoralism, combined with very small scale crop farming. Hence, in the future, poor pastoralists will be more engaged in mixed crop-livestock systems, than that they currently are. However, because of land claims from the "autochthone" crop farmers (chapter 2), it may happen that pastoralists are expropriated of the current cropping fields they are using. In the event of such situation, poor pastoralists will have no other choice than, to move from this area, (this is already happening according to an employee of the veterinary services). Hence, they are forced to follow the stepping-out strategy, but without having collected assets to invest in new activities. Poor pastoralists may become labourer on crop farms in their current or other areas, or labourer for diverse type of activities in urban cities (Ayantunde et al., 2011).

The better-off pastoralists, with large herd sizes, will likely move to other areas such as the coastal areas of Benin and bordering countries, because of feed scarcity or they will shift to the stepping-out strategy. This strategy could be land acquisition for crop farming, in a more intensive crop-livestock system (Herrero et al., 2010) than that of the poor pastoralists (Slingerland, 2000). However, land is a very scarce asset in the study area and in Benin as a whole, where agriculture is the basis of livelihood for $70 \%$ of the rural populations. Moreover, land grabbing, i.e. land acquisition by local and foreign nationals for agricultural purposes, is increasing in West Africa 
Chapter 6

(GRAIN, 2012). In such situation, land will become highly priced so that it will be hard to afford for stepping-out pastoralists. Therefore, the better-off pastoralists may go for other activities than farming. Due to their relations with their fellow pastoralists in the Sahelian countries, they may invest in livestock trading with the coastal areas. Consumption of livestock products is expected to increased, due to the increase of income. Therefore, livestock trading, especially cattle trading between Sahelian and coastal countries, is an activity worth to invest in. The study area has three important livestock markets i.e. Mamassy Peul (Karimama district), Guene (Malanville district), Mongo (Kandi district), which supply the urban cities of the country but also urban cities of Nigeria. In livestock trading, the better-off pastoralists will hire labour from the poor pastoralists (with long experience in herding), for moving livestock to markets. They may also invest in education of their children, which may help them to step out of livestock-based livelihoods.

Stepping-up is very unlikely because it requires pastoralists to increase the scale of their current activity, which requires more land. Results of chapter 2 show that cropland is expanding, which may be compound by land grabbing. In such situation, it is unlikely that pastoralists, even the better-off ones, will be able to afford land that can sustain feed requirements of their current (or eventually larger) livestock holdings.

In summary, without change, the stepping-out strategy is the likely strategy for pastoralists in the area under study. Examples of the stepping-out strategy have been reported for Maasai pastoralists in East Africa. Most of the grazing lands of the Maasai have been converted into nature conservation areas. The Maasai are currently in a livelihood transition from traditional pastoralism to other activities. Coast (2002) found that $88 \%$ of Tanzanian and $46 \%$ of Kenyan Maasai pastoralists are now cultivating crops. Furthermore, intensification of livestock production through cattle crossbreeding is adopted by the Maasai of the Kajiado district in Kenya (BurnSilver, 2007; Galvin, 2009) which is a stepping-out strategy, different from the (mobile) pastoralism. In this transformed or transition system, (BurnSilver, 2007) found that Maasai pastoralists had less livestock holdings than in the past (from 159 to 62 Tropical Livestock Unit, 20 years later). Mongolians pastoralists have been settled due to land privatisation (Ojima and Chuluun, 2008), with disastrous consequences for rangeland ecosystems. Studies also reported that pastoralists are 
General Discussion

more engaged in schooling of their children (Wu et al., 2014) and in tourism activities.

In the event that no action is undertaken in favour of pastoralism, the pathway described in the previous section is likely to happen in the study area. That would imply that we also lose several ecosystem services currently provided by pastoralists and pastoral landscapes, such as carbon storage, diversity of plant communities, indigenous livestock diversity, pastoral cultural landscapes, and pastoral cultural heritage. If we want to sustain these ecosystem services, we for example can pay for these services (section 4.2) or engage pastoralists in nature conservation (section 4.3).

\subsubsection{Payment for ecosystem services provided by pastoralism}

According to the millennium ecosystem assessment (MEA, 2005), ecosystem services are the benefits people obtain from ecosystems. Such services include provisioning services such as food, feed (forage) and water, regulating services such as carbon storage, flood and disease control, cultural services such as spiritual, recreational, and cultural benefits and supporting services, such as nutrient cycling (MEA, 2005), that play an important role, for instance, in food and forage production. Pastoralism has been associated with the four categories of ecosystem services (CBD, 2010; Safriel and Adeel, 2005). Since the provisioning services consist of provision of food, such as meat and milk which are sold in ordinary markets, the focus of this section will be on the regulating, cultural and supporting services that pastoralism provides to humankind, and for which pastoralism could, therefore, be paid.

Payment for ecosystem services (PES) are mechanisms to invest in restoring and maintaining ecosystem and services they provide (Farley and Costanza, 2010). The idea behind the PES mechanism is that incentives cover the cost of providers or producers of ecosystem services based on a realistic value of such ecosystem services (Costanza et al., 2014). PES allows individual, public and private organisations to pay for the environmental (ecosystem) public goods such as carbon storage, crop pollination, biodiversity and water conservation, and cultural landscape (OterosRozas et al., 2012) or cultural heritage. PES programmes are part of the reduction of emissions from deforestation and degradation in developing countries. It is 
Chapter 6

developed as a strategy for meeting the climate change and sustainable development objectives of the convention framework on climate change of the United Nations.

Results of chapter 2 show that land used for grazing by pastoralists is being converted to cropland. Pastoralism allows multiple activities at the same time i.e. grazing and maintaining of dryland plant communities throughout the whole year. Cropping often allows only one species during a limited part of the year. So, pastoralism retains more biomass than crop farming and consequently plays an important role in carbon storage and sequestration, which is important in preventing and mitigating of greenhouse gas emissions. For instance, when grazing lands are converted into croplands, $95 \%$ of the aboveground carbon, and up to $50 \%$ of the belowground carbon can be lost (Reid et al., 2004). Results of chapter 3 demonstrate that grazing may enhance diversity of plant communities. Since plant diversity is important in ecosystem functioning, pastoralism, therefore, contributes to supporting services of dryland ecosystems. The positive effect of pastoralism on plant diversity is even more prominent when compared to crop production where the land covers only a limited plant diversity. Results of chapter 4 and 5 show that pastoralists have a wealth of knowledge that underlies their herding decisions, and knowledge about roles and functions of indigenous breeds. Such knowledge is important in maintaining the dryland landscape and indigenous livestock diversity. Pastoralism, therefore, is providing cultural services to humankind.

To maintain pastoralism in the drylands, and especially in regions where pastoralism is losing grazing lands, use of PES can be a promising pathway. Based on results of chapters 2, 3, 4 and 5, there are potentially three markets of PES for pastoralism in the drylands: the carbon market, the biodiversity market and the cultural landscape market. There may be more ecosystem services that pastoralism provides in the drylands. For an exhaustive list of such ecosystem services, a pastoralism-based framework proposed by Oteros-Rozas et al. (2012) can be used. This framework consists of sequential phases: i) characterisation of the social-ecological network associated with pastoralism, ii) preliminary identification and characterisation of ecosystem services, iii) evaluation of ecosystem services in biophysical, sociocultural and economic terms, and iv) future scenario planning for the analysis of social conflicts related to ecosystem services use and trade-offs as well as the proposal of management strategies. In practice, implementation of PES for pastoralism in the 
General Discussion

drylands will require institutional intervention and willingness. On the one hand, and given that pastoralists currently do not own land, governments could intervene with land use policies that secure lands to pastoralists, whereas on the other hand, governments could coordinate volunteering individuals willing to lease their lands to pastoralists. Land allocated for use by pastoralists should not be only for grazing, but also to secure corridors for livestock movement. So, in a PES system, landowners (i.e. crop farmers) could get paid for leasing out their lands to compensate the potential loss of production, while pastoralists will be paid for the ecosystem services they provide. Payment for landowners may be in cash, whereas payment for pastoralism may be the provision of grazing lands. In implementing PES for pastoralism, it is important to invest in permanent ecological monitoring of the grazing lands in order to avoid grassland degradation. This means that grazing intensity should be at an intermediate level, at which it can promote biodiversity and maintain a substantial vegetation cover.

PES has been implemented for forest, wildlife, biodiversity and watershed conservation. For instance, PES was performed for carbon sequestration in China (Yang et al., 2013), for agri-environmental services in Europe (Wynne-Jones, 2013), wildlife conservation in Kenya (Osano et al., 2013), biodiversity conservation in the United States (Ferraro and Kiss, 2002), in Latin America (Pagiola et al., 2005), and watershed protection in South Africa (Turpie et al., 2008). There are several challenges in implementing PES: i) identifying and understanding individual ecosystem services, ii) identifying the management intensity that maximizes the provision of an ecosystem service, iii) the scale at which an ecosystem service is provided to people, iv) ecosystem services can be context specific, and v) understanding the relationships (synergies and especially trade-offs) between ecosystem services. For most PES programs, the lack of information about the increase in ecosystem services generated by changes in practices remains its weak point (Pagiola et al., 2005). For example, in implementing PES for pastoralism in the drylands, there is a gap of knowledge about the amount of carbon that is retained by pastoralism on grassland vegetation compared to crop production (Dabasso et al., 2014). This may hamper the quantification of the ecosystem service provided for carbon sequestration. Another challenge in implementing PES for pastoralism is to find institutions, which will finance PES in the long run. Implementation of PES also involves assessment, monitoring and evaluation activities, which, to be efficient, 
require institutional arrangements: organisations (people) and regulations. In implementing, a risk of PES for pastoralism, could be that crop farmers are more interested in leasing land out to pastoralism than in crop production, which may affect food security. So, implementing PES for pastoralism may be challenging in practice. Nevertheless, it is important to raise the awareness of pastoral communities and policy makers about PES as a potential mechanism to sustain pastoralism in the drylands.

Implementation of PES for pastoralism requires land for grazing and for livestock movement. However, results of chapter 2 show a continuous trend of conversion of grazing lands into cropland, which may hamper the availability of land. This situation may become worse even by land grabbing for agriculture by local and foreign land acquirers (GRAIN, 2012). It is, therefore, important to look at another alternative in order to maintain pastoralism in the drylands, such as pastoralism in association with nature conservation.

\subsubsection{Pastoralism in association with nature conservation}

Protected areas are important for biodiversity conservation worldwide. Results of chapter 3 show that grazing by domestic livestock inside and in the periphery of the WBR did not hamper biodiversity because of its intermediate grazing intensity. Pastoralism could be allowed, therefore, in the peripheral sections of the park, and so be a buffer against pressure of expanding crop farming without affecting the nature values of the park. No doubt that this will face several challenges.

The first is the reluctant opinion of conservation areas managers, who are still influenced by the theory of the "tragedy of the commons" (Hardin, 1968). To overcome this reluctance, sharing of experience in other conservation areas combining domestic grazing and wildlife conservation can be of help. However, such experience is poorly reported in literature as grazing by domestic livestock has been portrayed as incompatible with wildlife conservation. As a consequence, cattle were forcibly removed from the Ruaha National Park in Tanzania (Walsh, 2012). Livestock has consistently entered, and subsequently been removed from protected areas in South Asia (Das, 2008), Latin America (Downie, 2008), in North America, and Central Africa (in Democratic Republic of Congo) under the pretexts that livestock are detrimental to conservation efforts (Butt, 2014). Experimentation with 
General Discussion

combinations of nature conservation and pastoralism, therefore, can yield insight into how to better integrate these two forms of land use.

A second challenge is the ecological assessment, monitoring and evaluation activities required to constantly inform about the state of the grassland in order to make adjustments to the grazing regime if required. Ecological assessment, monitoring and evaluation can be of high cost.

Third, disease transmission between wildlife and livestock poses a risk. Assessing the risk of disease transmission between wildlife and livestock is important, and usually extremely difficult (Morgan et al., 2006). Livestock and wildlife share diseases that can be mutually transmitted. An example is foot-and-mouth disease for which buffaloes (Syncerus caffer) are the reservoir, and it can be transferred to cattle, with severe consequences. Many other important infectious diseases including rift valley fever, malignant catarrhal fever and tuberculosis are prevalent in both wild and domestic ruminants and may be transmitted between them (Siembieda et al., 2011; Worthington and Bigalke, 2001). To avoid disease contamination and spread, the pastoral buffer zone should be marked and set around the WBR. Pastoralists should only graze in this area, to avoid contact with wild animals. However, how to avoid the entry of wildlife in this zone is challenging, even impossible in reality, unless the area is fenced. Fencing has showed disastrous consequence for rangeland ecosystems in South Africa.

Fourth, predation of livestock by wild carnivores, such as lions, could be source of tension between pastoralists and conservation area authorities (Chaminuka et al., 2012; Karanth et al., 2013). To avoid such tension, appropriate compensation of killed domestic animals should be negotiated with pastoralists. This requires a compensation fund.

Fifth, control of domestic livestock and herders is challenging due to livestock mobility. Grazing in the pastoral buffer zone will be only for pastoralists. This requires pastoralists to collaborate with the WBR authority in informing about their fellows who do not respect the set regulations. In practice, pastoral communities are hierarchical societies with strong traditional institutions. Enforcement of those regulations can benefit from such pastoral institutions. The use of new technologies such as the GPS collar, which track movement, density and distribution of livestock, can improve the control of livestock grazing the pastoral buffer zone. Results of 
Chapter 6

ecological monitoring may recommend adjustments, the decrease of number of livestock allowed grazing in the area and consequently displacement of livestock to other areas. Appropriate regulations should be set with regard to that.

\subsection{Increasing vulnerability of pastoralists}

Options to sustain pastoralism in its current form are limited. Pastoralists will become more vulnerable because of the encroachment of crop farming and an unfavourable land tenure, which are drivers of pastoralists vulnerability in Africa (López-i-Gelats et al., 2016). With the projected extreme climatic events following climate change such as more and prolonged droughts in the drylands (IPCC, 2007), it is likely that this situation will worsen. Drought poses serious challenges for populations whose livelihoods depend principally on natural resources (Nicholson, 2014), such as pastoralists. The impact of droughts in pastoral system is livestock losses due to mortality (Opiyo et al., 2015), which undermine other coping and adaptation strategies. Without any change, pressure on pastoralists will continue and this will have a negative effect on their activities as well as their lifestyle.

\subsection{General conclusions}

The general aim of this thesis was to understand the relations between pastoralism and its changing natural environment. Here are key conclusions of this thesis:

- Cropland expansion was the direct driver of decrease of grazing land; indirect drivers of the decrease of grazing land were population growth and the associated increases in demands for food crop products, and governmental policies stimulating cotton cultivation.

- Expansion of cropland, cropping by pastoralists and the incomplete implementation of the WBR have triggered competition for land among stakeholders (crop farmers, pastoralists and authority of the WBR).

- Inside and in the periphery of the WBR, grazing did not hamper plant diversity because it is at an intermediate level. It enhances diversity of plant communities in line with predictions based on theory. This conclusion, however, contradicts with the common opinion of conservation areas managers and policy-makers.

- A high dissimilarity was detected between species prevalence in aboveground vegetation and soil seed banks. 
- Pastoralists had a common knowledge about soils, forages and livestock characteristics, which was present in all generations of pastoralists, and which differed only slightly among agro-ecological zones.

- Pastoralists' traditional ecological knowledge underlying their herding decisions was holistic, combining soils, forages and livestock characteristics.

- Pastoralists had a common knowledge about roles and functions of indigenous breeds, which was present in all generations of pastoralists and which was only slightly different between agro-ecological zones.

- Pastoralists preferred adaptive traits of breeds over productive traits to deal with the changing and unfavourable conditions of their environment.

- Options to maintain pastoralism in its current form are limited. The most likely strategy for pastoralists will be the stepping-out strategy.

- To maintain pastoralism, payments for ecosystem services or pastoralism in association with nature conservation are options to be considered, although they are very challenging. 


\section{Summary}

The competition for land, especially between pastoralists and crop farmers, but also between pastoralists and nature conservation institutions, has become an issue of major concern and cause of conflict. The Biosphere Reserve of W (WBR) in Benin Republic and its surrounding land are located in the agro-pastoral contact zone in West Africa, implying that land is suitable for crop farming and pastoralism, potentially enabling competition for land. In, and especially in the periphery of the WBR, natural vegetation (grazing land) is being converted into cropland. This not only implies a loss of grazing land with a specific biodiversity value, but it may also change the pastoral system. Changes in the pastoral system may lead to loss of pastoralists' traditional ecological knowledge (TEK). In addition it may compromise pastoralists' contribution to maintaining indigenous livestock diversity. To maintain the socio-economic and ecological benefits of pastoralism, it is important to understand pastoralists and their relations with their changing environment. The general aim of this thesis, therefore, was to understand the relations between pastoralism and its changing natural environment.

The first step towards understanding these relations is to get insight into drivers of land use change and competition for land in and around the WBR. The aim of chapter 2, therefore, was to describe and analyse i) land use changes in order to understand their drivers, and ii) the viewpoints of relevant stakeholders in order to understand the competition for land in and around the WBR. I collected quantitative and qualitative data about land use. Cropland area around WBR expanded, whereas grazing land reduced. Population growth and rising demand for food crops and cash crops, triggered by governmental support to the cotton sector, were indirect causes of grazing land reduction. Competing claims over land existed between crop farmers and pastoralists, among crop farmers, and among crop farmers, pastoralists, and the WBR authority based on past expropriation, unfair and incomplete implementation of the WBR regulations and the shifting lifestyle of pastoralists. Results of chapter 2 suggest that pastoralism is under threat and its survival depends on policies to protect grazing lands.

Subsequently, to study the impact of pastoralism on plant communities, I assessed in chapter 3 the effect of low (L) and high (H) grazing intensities on plant biodiversity in the aboveground vegetation and in the soil seed bank. The aim of chapter 3 was 
to evaluate whether the present grazing regime in the bordering zone of and inside the WBR affects plant community diversity by addressing the following subobjectives: i) to assess the effect of grazing intensity on plant abundance and species richness in the aboveground vegetation, ii) to assess the effect of grazing intensity on seed abundance and species richness in the soil seed bank, and iii) to assess the effect of grazing intensity on similarity of species prevalence between aboveground vegetation and soil seed bank. I made a plant inventory for the aboveground vegetation for $\mathrm{L}$ and $\mathrm{H}$ in 8 sampling sites. A pot experiment with a randomised block design was used to study seed germination of the upper and deeper soil layers of soil seed banks collected in the same sampling sites as where aboveground vegetation was inventorised. In aboveground vegetation, grazing increased overall species richness, especially that of forb species. In soil seed banks, grazing increased overall plant abundance, abundance of forbs and leguminous tree species, and species richness of forbs and leguminous tree species only. More plants and more species emerged from the upper than from the deeper soil layers. Annual species dominated aboveground vegetation and soil seed banks. A high dissimilarity was detected between species prevalence in aboveground vegetation and soil seed banks. Results of chapter 3 suggest that the current levels of grazing increase species diversity in WBR and that restoration of grasslands with more perennials may require human intervention.

Next, herding involves taking decisions and moving of livestock in search for feed. Herding decisions are based on assessment of soil characteristics, forage characteristics and livestock characteristics. Understanding how such characteristics relate to location and moment of herding may give insights in how pastoralists use natural resources and may give scope for sustainable land use planning and grassland conservation. Chapter 4, therefore, had the following objectives: i) to inventorise and assess how pastoralists characterise and quality soils and forages in their environment, ii) to analyse how soil, forage and livestock characteristics relate to herding decisions and iii) to determine whether TEK underlying herding decisions differs across generations. Data were collected through focus group discussions and individual interviews with 72 pastoralists, belonging to three generations and to three agro-ecological zones. Using a three-point scale (high, medium, low), four grasses and three tree forages were assessed in terms of nutritional quality to 
promote milk and meat production, health status and strength. Using their own visual criteria, pastoralists identified five different soils, which they selected for herding at different times of the year. Pokuri was the best soil because of its good drainage capacity, whereas Karaal was the worst because forage hardly grows on it. Perennials, such as Andropogon gayanus and Loxoderra ledermannii, were of high nutritional quality, whereas annuals such as Andropogon pseudapricus and Hyparrhenia involucrata were of low nutritional quality. Afzelia africana had high quality for milk production, whereas Khaya senegalensis had the highest quality for meat production, health and strength. Pastoralists first used soil, then forage and finally livestock characteristics to make herding decisions, a structured and prioritised reasoning. Pastoralists' TEK was not associated with generations, but with agro-ecological zones. This study suggests that pastoralists use a holistic approach, combining soil, vegetation and livestock TEK in herding decisions. Such TEK can guide restoration or improvement of grazing lands, and land use planning.

Finally, pastoralism is facing the loss and fragmentation of grazing lands, which might affect their production system. Changes in the pastoral production system can lead to changes in desired livestock traits, which may lead to loss of indigenous breeds. Understanding pastoralists' perception of indigenous breeds and their associated traits is of importance in order to prevent loss of livestock diversity, and to improve future production systems. The objectives of chapter 5 were to: i) inventorise indigenous breeds of cattle and their performance in selected traits, ii) analyse pastoralists' preferences for specific breeds and reasons, and ii) determine whether the knowledge on breeds and breed traits was being transmitted across generations and was consistent across agro-ecological zones. Data were collected from focus groups discussions and from individual interviews with 72 pastoralists. Interviewees belonged to three generations and to three agro-ecological zones in the periphery of the WBR. From the focus groups discussions we identified the most common breeds in the region (i.e. Keteeji, Jaliji, Bodeji, Tchiwali and Gudali) and the most relevant traits (i.e. milk production, meat production, endurance in walking and tolerance to trypanosomiasis) to assess cattle breeds according to pastoralists. Then, the individual interviewees scored the performance of cattle breeds in the four main traits based on a three-point scale (high, medium and low). Finally, we determined the consistency of pastoralists' knowledge across generations and agroecological zones. Keteeji was valued for its endurance and tolerance to 
trypanosomiasis, Bodeeji was highly valued for endurance and Gudali was perceived of high value for meat and milk production, but of low value for endurance. Keteeji was the preferred breed by the majority of the pastoralists (nearly 50\%), and especially for adaptive traits (i.e. withstanding hunger) instead of productive ones. Gudali was one the least preferred breed (11\%). $80 \%$ of pastoralists selected a preferred cattle breed based on non-productive traits, i.e. withstanding hunger, intelligence (obedience to herder) or withstanding disease. This study suggests that pastoralists preferred adaptive traits of breeds over production traits to deal with the changing and unfavourable conditions of their environment. Pastoralists' knowledge about breed traits did not differ between generations, but some differences appeared between agro-ecological zones.

In chapter 6, the future of pastoralism was discussed, in light of results of the previous chapters. The discussion revealed that, with the ongoing loss of grazing lands, and depending on their livestock holdings, there are three possible livelihoods strategies for pastoralists: hanging-in, stepping-up, and stepping-out. Out of these three livelihood strategies, the stepping-up is unlikely. Poor pastoralists will use the hanging-in strategy in the short or mid-term, which is keeping the mobile pastoralism, but on very marginal lands and in combination with small size crop farming. However, it is likely that this strategy is not sustainable in the long run and, eventually, the poor pastoralists will be stepping-out from such activity or even leave the area (e.g. migration to urban and peri-urban areas). The better-off pastoralists will likely leave the region, because their extensive herds (their wealth) cannot be fed in the current situation. Eventually, the better-off pastoralists will use the steppingout strategy by engaging in livestock trading, in order to supply the urban regions of the country, but also cities in Nigeria. Two possible institutional intervention could help maintain pastoralism in the area. These interventions are i) payments for ecosystem services provided by pastoralism, in terms of granting land for grazing and in economic support to land leasers, and ii) association of pastoralism with nature conservation, in so-called pastoral buffer zones. In practice, however, the implementation of these two interventions is very challenging. Finally, the discussion concludes that options to maintain pastoralism are very limited in the long term, which implies an increasing vulnerability of pastoralists and pastoral lifestyle in the short to medium term. 


\section{References}

Admasu, T., Abule, E., Tessema, Z., 2010. Livestock-rangeland management practices and community perceptions towards rangeland degradation in South Omo zone of Southern Ethiopia. Livestock Research for Rural Development 22. http://www.lrrd.org/lrrd22/1/tere22005.htm.

Agrawal, A., Redford, K., 2009. Conservation and Displacement: An Overview. Conservation and Society 7, 1-10.

Agresti, A., 2007. Residuals for cells in a contingency table, in: Agresti, A. (Ed.), An Introduction to Categorical Data Analysis Second Edition ed. JohnWiley \& Sons Inc., Hoboken, NJ, USA, pp. 3839.

Anderson, S., 2003. Animal genetic resources and sustainable livelihoods. Ecological Economics 45, 331-339.

Angassa, A., Oba, G., 2010. Effects of grazing pressure, age of enclosures and seasonality on bush cover dynamics and vegetation composition in southern Ethiopia. Journal of Arid Environments 74, 111-120.

ANOPER, 2014. Situation de l'élevage et des l'éleveurs de ruminants au Benin. Analyse et perspectives. http://www.inter-reseaux.org/IMG/pdf/DOS_ANNEXE_ANOPER-1.pdf

Avakoudjo, J., Mama, A., Toko, I., Kindomihou, V., Sinsin, B., 2014. Dynamics of land use in the W National Park and its surrounding northwest of Benin. International Journal of Biological and Chemical Sciences 8, 2608-2625.

Ayalew, W., King, J.M., Bruns, E., Rischkowsky, B., 2003. Economic evaluation of smallholder subsistence livestock production: lessons from an Ethiopian goat development program. Ecological Economics 45, 473-485.

Ayantunde, A.A., Briejer, M., Hiernaux, P., Udo, H.M., Tabo, R., 2008a. Botanical knowledge and its differentiation by age, gender and ethnicity in Southwestern Niger. Human Ecology 36, 881-889.

Ayantunde, A.A., de Leeuw, J., Turner, M.D., Said, M., 2011. Challenges of assessing the sustainability of (agro)-pastoral systems. Livestock Science 139, 30-43.

Ayantunde, A.A., Fernández-Rivera, S., Hiernaux, P.H., Tabo, R., 2008b. Implications of restricted access to grazing by cattle in wet season in the Sahel. Journal of Arid Environments 72, 523-533.

Ayantunde, A.A., Kango, M., Hiernaux, P., Udo, H.M., Tabo, R., 2007. Herders' perceptions on ruminant livestock breeds and breeding management in southwestern Niger. Human Ecology $35,139-149$.

Barfield, T.J., 1993. The nomadic alternative. Prentice-Hall, Englewood Cliffs, NJ, USA.

Barton, K., Koricheva, J., Associate Editor, T., x, Lynn, A., Editor: Donald, L.D., 2010. The Ontogeny of Plant Defense and Herbivory: Characterising General Patterns Using Meta-Analysis. The American Naturalist 175, 481-493.

Bassett, T.J., Turner, M.D., 2007. Sudden shift or migratory drift? Fulbe herd movements to the Sudano-Guinean region of West Africa. Human Ecology 35, 33-49.

Baudron, F., Corbeels, M., Andersson, J.A., Sibanda, M., Giller, K.E., 2011. Delineating the drivers of waning wildlife habitat: The predominance of cotton farming on the fringe of protected areas in the Mid-Zambezi Valley, Zimbabwe. Biological Conservation 144, 1481-1493.

Baudron, F., Corbeels, M., Monicat, F., Giller, K.E., 2009. Cotton expansion and biodiversity loss in African savannahs, opportunities and challenges for conservation agriculture: a review paper based on two case studies. Biodiversity and Conservation 18, 2625-2644.

Behmanesh, B., Barani, H., Sarvestani, A.A., Shahraki, M., Sharafatmandrad, M., 2015. Rangeland degradation assessment: a new strategy based on indigenous ecological knowledge of pastoralists. Solid Earth Discussions 7, 2999-3019.

Behnke, R.H., Scoones, I., Kerven, C., 1993. Range ecology at disequilibrium. Overseas Development Institute, London, UK.

Benoit, M., 1999. Peuplement, violence endémique et rémanence de l'espace sauvage en Afrique de l'Ouest. Espace, populations, sociétés, 29-51.

Berkes, F., Colding, J., Folke, C., 200o. Rediscovery of traditional ecological knowledge as adaptive management. Ecological Applications 10, 1251-1262. 
Bernués, A., Tello-García, E., Rodríguez-Ortega, T., Ripoll-Bosch, R., Casasús, I., 2016. Agricultural practices, ecosystem services and sustainability in High Nature Value farmland: Unraveling the perceptions of farmers and nonfarmers. Land Use Policy 59, 130-142.

Biazin, B., Sterk, G., 2013. Drought vulnerability drives land-use and land cover changes in the Rift Valley dry lands of Ethiopia. Agriculture, Ecosystems \& Environment 164, 100-113.

Biernacki, P., Waldorf, D., 1981. Snowball Sampling: Problems and Techniques of Chain Referral Sampling. Socilogical Methods \& Research 10, 141-163.

Bierschenk, T., 1995. Rituels politiques et construction de l'identité ethnique des Peuls au Bénin. Cahiers des Science Humaines 31, 457-484.

Billand, A., De Visscher, M.N., Kidjo, F.C., Compaore, A., Boureima, A., Morel, A., Camara, L., Czesnik, F., Ahoyo Adjovi, N.R., 2005. Plan d'Aménagement et de Gestion (2006-2010) de la Réserve de Biosphère Transfrontalière W - Etat des lieux. Ecosystèmes Protégés en Afrique Sahélienne (ECOPAS), Ouagadougou, Burkina Faso.

Blein, R., Soulé, B.G., 2013. The challenges in regard to commercialization and the regional cereal market, Thematic Paper No. 3- Summary. ROPPA.

http://www.inter-reseaux.org/IMG/pdf_Commercialization_and_regional_market__Summary_No3.pdf

Blench, R., 1999. Traditional livestock breeds: geographical distribution and dynamics in relation to the ecology of West Africa. Overseas Development Institute, London, UK.

Blench, R., 2001. 'You Can't Go Home Again': Pastoralism in the New Millennium. Overseas Development Institute, London, UK.

Boer, M., Stafford Smith, M., 2003. A plant functional approach to the prediction of changes in Australian rangeland vegetation under grazing and fire. Journal of Vegetation Science 14, 333344 .

Bouché, P., Aboudou, M., Amadou, S.A., Amahowe, O.I., Djibey, M., Halilou-Malam-Garba, H., Hassane, Z.I., Hebie, L., Kougnati, S.J., Makadassou, A., 2012. Inventaire aérien de l'écosysteme W-Arly-Pendjari, Mai-Juin 2012. CITES-MIKE, WAP/UNOPS Benin-Burkina Faso-Niger, Ouagadougou, Burkina Faso.

Boval, M., Angeon, V., Rudel, T., 2017. Tropical grasslands: A pivotal place for a more multi-functional agriculture. Ambio 46, 48-56.

Briske, D.D., Fuhlendorf, S.D., Smeins, F.E., 2005. State-and-Transition Models, Thresholds, and Rangeland Health: A Synthesis of Ecological Concepts and Perspectives. Rangeland Ecology \& Management 58, 1-10.

Buldgen, A., Dieng, A., 1997. Andropogon gayanus var. bisquamulatus: a fodder crop for the tropics. Administration Générale de la Coopération du Développement (AGCD), Bruxelles, Belgium.

Burgoyne, C., Kelso, C., Ahmed, F., 2015. Human activity and vegetation change around Mkuze Game Reserve, South Africa. South African Geographical Journal, 1-18.

BurnSilver, S.B., 2007. Pathways of continuity and change: Diversification, intensification and mobility in Maasai. Colorado State University, Fort Collins, CO, USA.

Butt, B., 2011. Coping with Uncertainty and Variability: The Influence of Protected Areas on Pastoral Herding Strategies in East Africa. Human Ecology 39, 289-307.

Butt, B., 2014. The political ecology of 'incursions': Livestock, protected areas and socio-ecological dynamics in the mara region of kenya. Africa $84,614-637$.

Cardinale, B.J., Duffy, J.E., Gonzalez, A., Hooper, D.U., Perrings, C., Venail, P., Narwani, A., Mace, G.M., Tilman, D., Wardle, D.A., Kinzig, A.P., Daily, G.C., Loreau, M., Grace, J.B., Larigauderie, A., Srivastava, D.S., Naeem, S., 2012. Biodiversity loss and its impact on humanity. Nature 486, $59-67$.

Catley, A., Lind, J., Scoones, I., 2013. Pastoralism and development in Africa: dynamic change at the margins. Routledge, London and New York, UK and NY, USA.

Cavanagh, C.J., Benjaminsen, T.A., 2015. Guerrilla agriculture? A biopolitical guide to illicit cultivation within an IUCN Category II protected area. The Journal of Peasant Studies 42, 725-745.

CBD, 2005. Handbook of the Convention on Biological Diversity Including its Cartagena Protocol on Biosafety, 3rd ed. Secretariat of CBD, Montreal, Canada. 
CBD, 2010. Pastoralism, nature conservation and development: A good practice guide. Secretariat of CBD, Montreal, Canada.

Chambers, R., 1994. Participatory rural appraisal (PRA): Challenges, potentials and paradigm. World development 22, 1437-1454.

Chaminuka, P., McCrindle, C.M.E., Udo, H.M.J., 2012. Cattle Farming at the Wildlife/Livestock Interface: Assessment of Costs and Benefits Adjacent to Kruger National Park, South Africa. Society \& Natural Resources 25, 235-250.

Chang, C., Koster, H.A., 1994. Introduction, in: Chang, C., Koster, H.A. (Eds.), Pastoralists at the periphery: herders in a capitalist world. The University of Arizona Press, Tuscon, AZ, USA, pp. 115.

Chang, J., Symes, W.S., Lim, F., Carrasco, L.R., 2016. International trade causes large net economic losses in tropical countries via the destruction of ecosystem services. Ambio 45, 387-397.

Child, R.D., Heady, H.F., Hickey, W.C., Peterson, R.A., Piper, R.D., 1984. Arid and semi-arid lands: Sustainable use and management in developing countries. Winrock International, Morrilton, Arkansas, USA.

Clerici, N., Bodini, A., Eva, H., Grégoire, J.-M., Dulieu, D., Paolini, C., 2007. Increased isolation of two Biosphere Reserves and surrounding protected areas (WAP ecological complex, West Africa). Journal for Nature Conservation 15, 26-40.

Coast, E., 2002. Maasai socioeconomic conditions: a cross-border comparison. Human Ecology 30, 79-105.

Collins, S.L., Knapp, A.K., Briggs, J.M., Blair, J.M., Steinauer, E.M., 1998. Modulation of Diversity by Grazing and Mowing in Native Tallgrass Prairie. Science 280, 745-747.

Connell, J.H., 1978. Diversity in Tropical Rain Forests and Coral Reefs. Science 199, 1302-1310.

Convers, A., Chaibou, I., Binot, A., Dulieu, D., 2007. La gestion de la transhumance dans la zone d'influence du parc régional du W par le programme Ecopas. une «approche projet» pour l'aménagement de la périphérie du parc. VertigO-la revue électronique en sciences de l'environnement [En ligne], Hors-série 4 | novembre 2007, mis en ligne le 27 mai 2008. Accessed on January 15th, 2017. http://vertigo.revues.org/761.

Costanza, R., de Groot, R., Sutton, P., van der Ploeg, S., Anderson, S.J., Kubiszewski, I., Farber, S., Turner, R.K., 2014. Changes in the global value of ecosystem services. Global Environmental Change 26, 152-158.

Dabasso, B.H., Oba, G., Roba, H.G., 2012. Livestock-based knowledge of rangeland quality assessment and monitoring at landscape level among borana herders of northern Kenya. Pastoralism: Research, Policy and Practice 2, 1-13.

Dabasso, B.H., Taddese, Z., Hoag, D., 2014. Carbon stocks in semi-arid pastoral ecosystems of northern Kenya. Pastoralism 4, 5.

Das, K.B., 2008. The policy of reduction of cattle populations from protected areas: a case study from Buxa Tiger Reserve, India. Conservation and Society 6, 185-189.

Davies, J., Hatfield, R., 2007. The Economics of Mobile Pastoralism: A Global Summary. Nomadic Peoples 11, 91-116.

Davies, J., Herrera, P., Ruiz-Mirazo, J., Mohamed-Katerere, J., Hannam, I., Nuesri, E., 2016. Improving governance of pastoral lands. FAO, Rome.

Davies, J., Niamir-Fuller, M., Kerven, C., Bauer, K., 2010. Extensive livestock production in transition: The future of sustainable pastoralism, in: Steinfeld, H., Mooney, H.A., Schneider, F., Neville, L.E. (Eds.), Livestock in a Changing Landscape, Volume 1: Drivers, Consequences, and Responses. Island Press, Washington, USA, pp. 285-308

Davis, D.K., 2005. Indigenous knowledge and the desertification debate: problematising expert knowledge in North Africa. Geoforum 36, 509-524.

de Haan, C., 2016. Prospects for Livestock-Based Livelihoods in Africa's Drylands. The World Bank, Washington DC, USA.

De Haan, C., Dubern, E., Garancher, B., Quintero, C., 2016. Pastoralism Development in the Sahel. World Bank, Washington DC, USA. 
De Haan, L., van Driel, A., Kruithof, A., 1990. From symbiosis to polarization? Peasants and pastoralists in northern Benin. Indian Geographical Journal 65, 51-65.

De Haan, L.J., 1997. Agriculteus et elveurs au Nord-Benin, Ecologie et genre de vie. Karthala, Paris, France.

DeFries, R., Hansen, A., Newton, A.C., Hansen, M.C., 2005. Increasing isolation of protected areas in tropical forests over the past twenty years. Ecological Applications 15, 19-26.

Delgado, C., Rosegrant, M., Steinfeld, H., Ehui, S., Courbois, C., 2001. Livestock to 2020: the next food revolution. Outlook on Agriculture 30, 27-29.

Dìaz, S., Cabido, M., 2001. Vive la différence: plant functional diversity matters to ecosystem processes. Trends in Ecology \& Evolution 16, 646-655.

Díaz, S., Lavorel, S., McIntyre, S.U.E., Falczuk, V., Casanoves, F., Milchunas, D.G., Skarpe, C., Rusch, G., Sternberg, M., Noy-Meir, I., Landsberg, J., Zhang, W.E.I., Clark, H., Campbell, B.D., 2007. Plant trait responses to grazing - a global synthesis. Global Change Biology 13, 313-341.

Dorward, A., Anderson, S., Bernal, Y.N., Vera, E.S., Rushton, J., Pattison, J., Paz, R., 2009. Hanging in, stepping up and stepping out: livelihood aspirations and strategies of the poor. Development in Practice 19, 240-247.

Dossa, L.H., Wollny, C., Gauly, M., 2007. Smallholders' perceptions of goat farming in southern Benin and opportunities for improvement. Tropical animal health and production 39, 49-57.

Downie, A., 2008. 'Brazil confiscates cattle to protect its rain forest', RedoOrbit News. http://www.redorbit.com/news/science/1451038/brazil_confiscates_cattle_to_protect_its_rai $\mathrm{n} \_$forest/. Accessed on December $15^{\text {th }}, 2017$.

Dreber, N., Esler, K.J., 2011. Spatio-temporal variation in soil seed banks under contrasting grazing regimes following low and high seasonal rainfall in arid Namibia. Journal of Arid Environments $75,174-184$.

Elo, S., Kyngäs, H., 2008. The qualitative content analysis process. Journal of Advanced Nursing 62, 107-115.

Fan, M., Li, W., Zhang, C., Li, L., 2014. Impacts of Nomad Sedentarisation on Social and Ecological Systems at Multiple Scales in Xinjiang Uyghur Autonomous Region, China. Ambio 43, 673-686.

FAO, 2001. Pastoralism in the new millennium. FAO Animal Production and Health Paper 150, Rome, Itlay.

FAO, 2007. Global Plan of Action for Animal Genetic Resources and the Intertaken Declaration. FAO's Commission on genetic resources for food and agriculture, Rome, Italy.

FAO, 2009. Livestock keepers-guardians of biodiversity. Animal Production and Health Paper. No. 167 Rome, Italy.

FAO, 2013. In vivo conservation of animal genetic resources. FAO Animal Production and Health Guidelines. No. 14. Rome, Italy.

FAO, 2015. The Second Report on the State of the World's Animal Genetic Resources for Food and Agriculture. FAO Commission on Genetic Resources for Food and Agriculture Assessments, Rome, Italy.

FAO, 2016a. Domesticated animal diversity information system. DAD-is. http://dad.fao.org/, Accessed on December $15^{\text {th }}, 2016$.

FAO, 2016b. Pastoralist knowledge hub. http://www.fao.org/pastoralist-knowledge-hub/en/, Accessed on January 20th, 2017.

FAOSTAT, 2017. FAO statistics for Benin country. http://www.fao.org/faostat/en/\#data/QA, accessed on January $12^{\text {th }}, 2017$.

Farley, J., Costanza, R., 2010. Payments for ecosystem services: From local to global. Ecological Economics 69, 2060-2068.

Felius, M., 1995. Cattle breeds: an encyclopedia. Misset, Doetinchem, the Netherlands.

Ferraro, P.J., Kiss, A., 2002. Direct Payments to Conserve Biodiversity. Science 298, 1718-1719.

Foley, J.A., Ramankutty, N., Brauman, K.A., Cassidy, E.S., Gerber, J.S., Johnston, M., Mueller, N.D., O/'Connell, C., Ray, D.K., West, P.C., Balzer, C., Bennett, E.M., Carpenter, S.R., Hill, J., Monfreda, C., Polasky, S., Rockstrom, J., Sheehan, J., Siebert, S., Tilman, D., Zaks, D.P.M., 2011. Solutions for a cultivated planet. Nature 478, 337-342. 
Fratkin, E., Mearns, R., 2003. Sustainability and pastoral livelihoods: lessons from East African Maasai and Mongolia. Human organisation 62, 112-122.

Galvin, K.A., 2009. Transitions: Pastoralists Living with Change. Annual Review of Anthropology 38, $185-198$.

Gaoue, O.G., Ticktin, T., 2009. Fulani knowledge of the ecological impacts of Khaya senegalensis (Meliaceae) foliage harvest in Benin and its implications for sustainable harvest. Economic Botany 63, 256-270.

Garcia, O.A., Bergés, A.Z., Perch, C., 2016. FAO's and IFAD's Engagement in Pastoral Development Joint Evaluation Synthesis. http://www.fao.org/3/a-bd503e.pdf

Gaughan, J.B., Mader, T.L., 2014. Body temperature and respiratory dynamics in un-shaded beef cattle. International Journal of Biometeorology 58, 1443-1450.

Giannecchini, M., Twine, W., Vogel, C., 2007. Land-cover change and human-environment interactions in a rural cultural landscape in South Africa. Geographical Journal 173, 26-42.

Gibbs, H.K., Ruesch, A.S., Achard, F., Clayton, M.K., Holmgren, P., Ramankutty, N., Foley, J.A., 2010. Tropical forests were the primary sources of new agricultural land in the 1980 s and 1990s. Proceedings of the National Academy of Sciences 107, 16732-16737.

Gibson, J., Gamage, S., Hanotte, O., Iñiguez, L., Maillard, J., Rischkowsky, B., Semambo, D., Toll, J., 2006. Options and strategies for the conservation of farm animal genetic resources: Report of an international workshop (7-10 November 2005, Montpellier, France), CGIAR System-wide Genetic Resources Programme (SGRP)/Bioversity International, Rome, Italy.

González Álvarez, D., 2013. Traditional Pastoralism in the Asturian Mountains: an Ethnoarchaeological View on Mobility and Settlement Patterns, in: Lugli, F., Stoppiello, A.A., Biagetti, S. (Eds.), Ethnoarchaeology:Current research and field methods. Archaeopress, Publishers of British Archaeological Reports, Rome, Italy, 13-14 May 2010, pp. 202-208.

Gotelli, N.J., Ellison, A.M., 2013. A Primer of Ecological Statistics, Second ed. Macmillan Education.

GRAIN, 2012. Land grabbing and food sovereignty in West and Central Africa. https://www.grain.org/article/entries/4575-land-grabbing-and-food-sovereignty-in-west-andcentral-africa.

Greter, A.M., Miller-Cushon, E.K., McBride, B.W., Widowski, T.M., Duffield, T.F., DeVries, T.J., 2015. Short communication: Limit feeding affects behavior patterns and feeding motivation of dairy heifers. Journal of Dairy Science 98, 1248-1254.

Hardin, G., 1968a. The Tragedy of the Commons. Science 162, 1243-1248.

Hardin, G.C.F.p.d.D., 1968b. The Tragedy of the Commons. Science 162, 1243-1248.

Harris, R.B., 2010. Rangeland degradationon the Qinghai-Tibetian plateau: A review of evidenceof its magnitude and causes. Journal of Arid Environments 74, 1-12.

Hartter, J., Dowhaniuk, N., MacKenzie, C.A., Ryan, S.J., Diem, J.E., Palace, M.W., Chapman, C.A., 2016. Perceptions of risk in communities near parks in an African biodiversity hotspot. Ambio 45, 692-705.

Hendricks, H.H., Bond, W.J., Midgley, J.J., Novellie, P.A., 2005. Plant species richness and composition a long livestock grazing intensity gradients in a Namaqualand (South Africa) protected area. Plant Ecology 176, 19-33.

Herrero, M., Thornton, P.K., Notenbaert, A.M., Wood, S., Msangi, S., Freeman, H.A., Bossio, D., Dixon, J., Peters, M., van de Steeg, J., Lynam, J., Rao, P.P., Macmillan, S., Gerard, B., McDermott, J., Seré, C., Rosegrant, M., 2010. Smart Investments in Sustainable Food Production: Revisiting Mixed Crop-Livestock Systems. Science 327, 822-825.

Hiernaux, P., 1998. Effects of grazing on plant species composition and spatial distribution in rangelands of the Sahel. Plant Ecology 138, 191-202.

Ho, P., Azadi, H., 2010. Rangeland degradation in North China: Perceptions of pastoralists. Environmental Research 110, 302-307.

Hoffman, M.T., Todd, S., 200o. A National Review of Land Degradation in South Africa: The Influence of Biophysical and Socio-economic Factors. Journal of Southern African Studies 26, 743-758. 
Hoffmann, I., 2004. Access to Land and Water in the Zamfara Reserve. A Case Study for the Management of Common Property Resources in Pastoral Areas of West Africa. Human Ecology 32, 77-105.

Hoffmann, I., 2010. Climate change and the characterisation, breeding and conservation of animal genetic resources. Animal genetics 41, 32-46.

Hoffmann, I., 2011. Livestock biodiversity and sustainability. Livestock Science 139, 69-79.

Hoffmann, I., Boerma, D., Scherf, B., 2011. The Global Plan of Action for Animal Genetic Resources The road to common understanding and agreement. Livestock Science 136, 7-14.

Hopfensperger, K.N., 2007. A review of similarity between seed bank and standing vegetation across ecosystems. Oikos 116, 1438-1448.

Houessou, L.G., Teka, A., Oumorou, M., Sinsin, B., 2012. Hemicryptophytes plant species as indicator of grassland state in semi-arid region: case study of W Biosphere Reserve and its surroundings area in Benin (West Africa). International Journal of Biological and Chemical Sciences 6, 12711280.

Houessou, L.G., Teka, O., Imorou, I.T., Lykke, A.M., Sinsin, B., 2013. Land use and land-cover change at "W" Biosphere Reserve and its surroundings areas in Benin Republic (West Africa). Environment and Natural Resources Research 3, 87-101.

Huntington, H.P., 200o. Using traditional ecological knowledge in science: methods and applications. Ecological Applications 10, 1270-1274.

INSAE, 2004. Cahier des villages et quartiers de ville: Département de l'Alibori. RGPH3. Benin Government, Cotonou, Benin.

INSAE, 2013. Resultats provisoires du RGPH4. Benin Government, Cotonou, Benin.

IPCC, 2007. Climate Change 2007: impacts, adaptation and vulnerability. Summary for policy makers. See http://www.ipcc.

Joachim, S., 2008. The Interprofessional Cotton Association in Benin. CTA, Wageningen, The Netherlands.

Karanth, K.K., Gopalaswamy, A.M., Prasad, P.K., Dasgupta, S., 2013. Patterns of human-wildlife conflicts and compensation: Insights from Western Ghats protected areas. Biological Conservation 166, 175-185.

Kassahun, A., Snyman, H., Smit, G., 2008. Impact of rangeland degradation on the pastoral production systems, livelihoods and perceptions of the Somali pastoralists in Eastern Ethiopia. Journal of Arid Environments 72, 1265-1281.

Kent, M., 2012. Vegetation description and data analysis: a practical approach, Second ed. John Wiley \& Sons, Oxford.

Kgosikoma, O., Mojeremane, W., Harvie, B.A., 2012. Pastoralists' perception and ecological knowledge on Savanna ecosystem dynamics in semi-arid Botswana. Ecology and Society 17, 27. http://dx.doi.org/10.5751/ES-05247-170427.

Koerner, S.E., Collins, S.L., 2014. Interactive effects of grazing, drought, and fire on grassland plant communities in North America and South Africa. Ecology 95, 98-109.

Köhler-Rollefson, I., 2003. Community-based management of animal genetic resources-with special reference to pastoralists, Community-based management of animal genetic resources. Proceedings of the workshop held in Mbabane, Swaziland, 7-11 May 2001, pp. 13-26. FAO, Rome, Italy. http://www.fao.org/3/a-y3970e.pdf

Köhler-Rollefson, I., Rathore, H.S., Mathias, E., 2009. Local breeds, livelihoods and livestock keepers' rights in South Asia. Tropical animal health and production 41, 1061-1070.

Landsberg, J., James, C.D., Maconochie, J., Nicholls, A.O., Stol, J., Tynan, R., 2002. Scale-related effects of grazing on native plant communities in an arid rangeland region of South Australia. Journal of Applied Ecology 39, 427-444.

Leloup, S., 2006. Investing in maintaining mobility in pastoral systems of the arid and semi-arid regions of sub-Saharan Africa. ALive: Partnership for Livestock Development, Poverty Alleviation and Sustainable Growth. http://www.fao.org/fileadmin/templates/lead/pdf/econf_o6-10_mobility.pdf 
Liao, C., Ruelle, M.L., Kassam, K.-A.S., 2016. Indigenous ecological knowledge as the basis for adaptive environmental management: Evidence from pastoralist communities in the Horn of Africa. Journal of Environmental Management 182, 70-79.

López-i-Gelats, F., Fraser, E.D.G., Morton, J.F., Rivera-Ferre, M.G., 2016. What drives the vulnerability of pastoralists to global environmental change? A qualitative meta-analysis. Global Environmental Change 39, 258-274.

Lutz, C., Kuiper, W.E., van Tilburg, A., 2006. Maize Market Liberalisation in Benin: A Case of Hysteresis. Journal of African Economies 16, 102-133.

Maboudou A., G., 2014. Networking, Social Capital and Gender Roles in the Cotton System in Benin. PhD Thesis. Wageningen University, The Netherlands.

MAEP, 2011. Plan stratégique de relance du secteur agricole. Benin Government, Cotonou, Benin.

Mangiafico, S.S., 2016. Association Tests for Nominal Variables, in: Mangiafico, S.S. (Ed.), Summary and Analysis of Extension Program Evaluation in R, version 1.5.o. Rutgers Cooperative Extension, New Brunswick, NJ, USA, pp. 393-401.

Mathias, E., Ilse, K., Jacob, W., 2005. Pastoralists, local breeds and the fight for livestock keepers' rights, Prepared for the PENHA 15th Anniversary Conference "Pastoralism in the Horn of Africa: Surviving against all odds. http://www.pastoralpeoples.org/docs/pastoralists_localbreeds_lkr_ en.pdf

McCabe, J.T., Leslie, P.W., DeLuca, L., 2010. Adopting Cultivation to Remain Pastoralists: The Diversification of Maasai Livelihoods in Northern Tanzania. Human Ecology 38, 321-334.

McDermott, J.J., Staal, S.J., Freeman, H.A., Herrero, M., Van de Steeg, J.A., 2010. Sustaining intensification of smallholder livestock systems in the tropics. Livestock Science 130, 95-109.

McGarigal, K., Cushman, S.A., 2002. Comparative evaluation of experimental approaches to the study of habitat fragmentation effects. Ecological Applications 12, 335-345.

McLafferty, I., 2004. Focus group interviews as a data collecting strategy. Journal of Advanced Nursing 48, 187-194.

McNaughton, S.J., 1979. Grazing as an Optimization Process: Grass-Ungulate Relationships in the Serengeti. The American Naturalist 113, 691-703.

MEA, 2005. Ecosystems and Human Well-Being: Current State and Trends, Vol. 1. Millennium Ecosystem Assessment, Island, Washington, DC, USA.

Meissner, R.A., Facelli, J.M., 1999. Effects of sheep exclusion on the soil seed bank and annual vegetation in chenopod shrublands of South Australia. Journal of Arid Environments 42, 117128.

Mekuria, W., Veldkamp, E., Haile, M., Nyssen, J., Muys, B., Gebrehiwot, K., 2007. Effectiveness of enclosure to restore degraded soils as a result of overgrazing in Tigray, Ethipia. Journal of Arid Environments 69, 270-284.

Milchunas, D.G., Sala, O.E., Lauenroth, W.K., 1988. A Generalized Model of the Effects of Grazing by Large Herbivores on Grassland Community Structure. The American Naturalist 132, 87-106.

Morgan, E.R., Lundervold, M., Medley, G.F., Shaikenov, B.S., Torgerson, P.R., Milner-Gulland, E.J., 2006. Assessing risks of disease transmission between wildlife and livestock: The Saiga antelope as a case study. Biological Conservation 131, 244-254.

Moritz, M., 2003. Commodization and the Pursuit of Piety: The Transformation of African Pastoral System. PhD dissertation. Univeristy of California, Los Angeles, USA.

Moritz, M., Kyle, B.R., Nolan, K.C., Patrick, S., Shaffer, M.F., Thampy, G., 2009. Too many people and too few livestock in West Africa? An evaluation of Sandford's thesis. J Dev Stud 45, 1113-1133.

Mortimore, M., 2010. Adapting to drought in the Sahel: Lessons for climate change. Wiley Interdisciplinary Reviews: Climate Change 1, 134-143.

Murwira, A., Garine-Wichatitsky, M.d., Zengeya, F., Poshiwa, X., Matema, S., Caron, A., Guerbois, C., Hellard, E., Fritz, H., 2012. Resource gradients and movements across the edge of transfrontier parks, Transfrontier conservation areas; people living on the edge. Routledge, New York and Abingdon (Can.), pp. 123-136.

Nacoulma, B.M.I., Schumann, K., Traoré, S., Bernhardt-Römermann, M., Hahn, K., Wittig, R., Thiombiano, A., 2011. Impacts of land-use on West African savanna vegetation: a comparison 
between protected and communal area in Burkina Faso. Biodiversity and Conservation 20, 33413362.

Neely, C., Bunning, S., Wilkes, A., 2009. Review of evidence on drylands pastoral systems and climate change. FAO, Rome, Italy.

Niamir-Fuller, M., 1999. Managing mobility in African rangelands. Intermediate Technology Publications, London, UK.

Nicely, R., 2014. Agricultural Situation Benin. GAIN Report. USDA. https://gain.fas.usda.gov/Recent\%20GAIN\%20Publications/Agricultural\%20Situation_Lagos _Benin_3-20-2014.pdf.

Nicholson, S.E., 2014. A detailed look at the recent drought situation in the Greater Horn of Africa. Journal of Arid Environments 103, 71-79.

Ningal, T., Hartemink, A.E., Bregt, A.K., 2008. Land use change and population growth in the Morobe Province of Papua New Guinea between 1975 and 2000. Journal of Environmental Management 87, 117-124.

Noy-Meir, I., Gutman, M., Kaplan, Y., 1989. Responses of Mediterranean Grassland Plants to Grazing and Protection. Journal of Ecology 77, 290-310.

Nugteren, H., Le Côme, C., 2016. Libérer le potentiel du pastoralisme pour développer l'Afrique de l'Ouest. KIT and SNV, Amsterdam, The Netherlands.

O'connor, T., 1996. Hierarchical control over seedling recruitment of the bunch-grass Themeda triandra in a semi-arid savanna. Journal of Applied Ecology, 1094-1106.

O'Connor, T.G., 2005. Influence of land use on plant community composition and diversity in Highland Sourveld grassland in the southern Drakensberg, South Africa. Journal of Applied Ecology 42, 975-988.

O'Connor, T.G., Pickett, G.A., 1992. The Influence of Grazing on Seed Production and Seed Banks of Some African Savanna Grasslands. Journal of Applied Ecology 29, 247-260.

Oba, G., 2012. Harnessing pastoralists' indigenous knowledge for rangeland management: three African case studies. Pastoralism: Research, Policy and Practice 2, 1-25.

Oba, G., Kaitira, L., 2006. Herder knowledge of landscape assessments in arid rangelands in northern Tanzania. Journal of Arid Environments 66, 168-186.

Oba, G., Vetaas, O.R., Stenseth, N.C., 2001. Relationships between biomass and plant species richness in arid-zone grazing lands. Journal of Applied Ecology 38, 836-845.

Obulbiga, M., Kaboré-Zoungrana, C.Y., 2007. Influence de la fumure azotée et du rythme d'exploitation sur la production de matière sèche et la valeur alimentaire de Andropogon gayanus Kunth au Burkina Faso. Tropicultura 25, 161-167.

Ojima, D., Chuluun, T., 2008. Policy changes in Mongolia: implications for land use and landscapes. in: Galvin, K.A., Reid, R.S., Behnke Jr, R.H., Hobbs, N.T. (Eds.), Fragmentation in semi-arid and arid landscapes : consequences for human and natural landscape. Springer, Dordrecht, The Netherlands, pp. 179-193.

Oldenbroek, J.K., 1999. Genebanks and the management of farm animal genetic resources. DLO Institute for Animal Science and Health, Lelystad, The Netherlands.

Olff, H., Ritchie, M.E., 1998. Effects of herbivores on grassland plant diversity. Trends in Ecology \& Evolution 13, 261-265.

Opiyo, F., Wasonga, O., Nyangito, M., Schilling, J., Munang, R., 2015. Drought Adaptation and Coping Strategies Among the Turkana Pastoralists of Northern Kenya. International Journal of Disaster Risk Science 6, 295-309.

Osano, P.M., Said, M.Y., de Leeuw, J., Ndiwa, N., Kaelo, D., Schomers, S., Birner, R., Ogutu, J.O., 2013. Why keep lions instead of livestock? Assessing wildlife tourism-based payment for ecosystem services involving herders in the Maasai Mara, Kenya. Natural Resources Forum 37, 242-256.

Oteros-Rozas, E., González, J.A., Martín-López, B., López, C.A., Zorrilla-Miras, P., Montes, C., 2012. Evaluating ecosystem services in transhumance cultural landscapesan interdisciplinary and participatory framework. Gaia-Ecological Perspectives for Science and Society 21, 185-193.

Oteros Rozas, E., Ontillera-Sánchez, R., Sanosa, P., Gómez-Baggethun, E., Reyes-García, V., González, J.A., 2013. Traditional Ecological Knowledge among transhumant pastoralists in Mediterranean 
Spain: learning for adaptation to global change. Ecology and Society 18, 33. http://dx.doi.org/10.5751/ES-05597-180333.

Ouédraogo-Koné, S., Kaboré-Zoungrana, C.Y., Ledin, I., 2008. Important characteristics of some browse species in an agrosilvopastoral system in West Africa. Agroforestry Systems 74, 213-221.

Ouedraogo, I., Tigabu, M., Savadogo, P., Compaoré, H., Odén, P., Ouadba, J., 2010. Land cover change and its relation with population dynamics in Burkina Faso, West Africa. Land Degradation \& Development 21, 453-462.

Pagiola, S., Arcenas, A., Platais, G., 2005. Can Payments for Environmental Services Help Reduce Poverty? An Exploration of the Issues and the Evidence to Date from Latin America. World development 33, 237-253.

Penning de Vries, F., Krul, J., Keulen, H.v., 1980. Productivity of Sahelian rangelands in relation to the availability of nitrogen and phosphorus from the soil, Nitrogen cycling in West African ecosystems: proceedings of a workshop, IITA, 11-15 Dec 1978. SCOPE/UNEP Royal Swedish Academy of Sciences, pp. 95-113.

Pope, C., Mays, N., 1995. Reaching the parts other methods cannot reach: an introduction to qualitative methods in health and health services research. British Medical Journal 311, 42-45.

Proulx, M., Mazumder, A., 1998. Reversal of grazing impact on plant species richness in nutrient-poor vs. Nutrient-rich ecosystems. Ecology 79, 2581-2592.

R Core Team, 2016. R: A language and environment for statistical computing. R Foundation for Statistical Computing, Vienna, Austria.

Rege, J., Aboagye, G., Tawah, C., 1994. Shorthorn cattle of West and Central Africa. IV. Production characteristics. FAO World Animal Review 78, 33-48.

Reid, R., Kruska, R., Muthui, N., Taye, A., Wotton, S., Wilson, C., Mulatu, W., 20oo. Land-use and land-cover dynamics in response to changes in climatic, biological and socio-political forces: the case of southwestern Ethiopia. Landscape Ecology 15, 339-355.

Reid, R.S., Galvin, K.A., Kruska, R.S., 2008. Global significance of extensive grazing lands and pastoral societies: an introduction, Fragmentation in semi-arid and arid landscapes. Springer, pp. 1-24.

Reid, R.S., Thornton, P.K., Kruska, R.L., 2004. Loss and fragmentation of habitat for pastoral people and wildlife in East Africa: concepts and issues. African Journal of Range and Forage Science 21, 171-181.

Richards, J.A., 2013. Remote Sensing Digital Image Analysis : An Introduction, 5th ed. Springer, Berlin, Germany.

Roba, H.G., Oba, G., 2009. Efficacy of integrating herder knowledge and ecological methods for monitoring rangeland degradation in northern Kenya. Human Ecology 37, 589-612.

Roberts, H., 1981. Seed banks in soils. Advances in applied biology 6, 1-55.

Rutherford, M.C., Powrie, L.W., 2011. Can heavy grazing on communal land elevate plant species richness levels in the Grassland Biome of South Africa? Plant Ecology 212, 1407-1418.

Safriel, U., Adeel, Z., 2005. Dryland systems, Ecosystems and Human Well-Being: Current State and Trends, Vol. 1. Millennium Ecosystem Assessment, Island, Washington, DC, USA, pp. 623-662.

Savadogo, P., Sanou, L., Djibril, D.S., Bognounou, F., Thiombiano, A., 2016. Relationships between soil seed banks and above-ground vegetation along a disturbance gradient in the W Park transboundary biosphere reserve, West Africa. Journal of Plant Ecology, 1-15.

Scoones, I., 1995. Exploiting heterogeneity:habitat use by cattle in dryland Zimbabwe. Journal of Arid Environments 29, 221-237.

Scott, K., Setterfield, S., Douglas, M., Andersen, A., 2010. Soil seed banks confer resilience to savanna grass-layer plants during seasonal disturbance. Acta Oecologica 36, 202-210.

Seymour, C.L., Milton, S.J., Joseph, G.S., Dean, W.R.J., Ditlhobolo, T., Cumming, G.S., 2010. Twenty years of rest returns grazing potential, but not palatable plant diversity, to Karoo rangeland, South Africa. Journal of Applied Ecology 47, 859-867.

Shabtay, A., 2015. Adaptive traits of indigenous cattle breeds: The Mediterranean Baladi as a case study. Meat Science 109, 27-39.

Siembieda, J.L., Kock, R.A., McCracken, T.A., Newman, S.H., 2011. The role of wildlife in transboundary animal diseases. Animal Health Research Reviews 12, 95-111. 
Simo, G., Rayaisse, J.B., 2015. Challenges facing the elimination of sleeping sickness in west and central Africa: sustainable control of animal trypanosomiasis as an indispensable approach to achieve the goal. Parasites \& vectors 8, 640-640.

Slingerland, M., 200o. Mixed Farming : Scope and Constraints in West African Savanna. PhD thesis, Wageningen University, The Netherlands.

Snyman, H., van Wyk, A.-E., 2005. The effect of fire on the soil seed bank of a semi-arid grassland in South Africa. South African Journal of Botany 71, 53-60.

Snyman, H.A., 2004. Soil seed bank evaluation and seedling establishment along a degradation gradient in a semi-arid rangeland. African Journal of Range \& Forage Science 21, 37-47.

Stewart, D.W., Shamdasani, P.N., 2014. Analysing focus group data, in: Stewart, D.W., Shamdasani, P.N. (Eds.), Focus groups: Theory and practice. Sage publications, Los Angeles, USA.

Swanson, D.A., Tayman, J., 2012. Subnational Population Estimates. Springer, London, UK.

Swift, J., 1988. Major issues in pastoral development with special emphasis on selected African countries. FAO, Rome, Italy.

Tamou, C., 2002. Etat des lieux quantitatif et spatialisé de la transhumance dans la zone peripherique du Parc National du W en Republique du Benin. MSc thesis, Université d' Abomey-Calavi, Benin.

Tamou, C., 2011. Dynamique des marchés a bétail au Benin: Implications du marché à du village Alibori and la commune de Banikoara. Thèse de Master complémentaire, Gembloux AgroBioTech, Université de Liège, Belgique..

Tamou, C., Ripoll-Bosch, R., de Boer, J.M.I., Oosting, J.S., 2016a. Pastoralists in a changing environment: the competition for grazing land in and around the W Biosphere Reserve, Benin Republic. Manuscript submitted for publication.

Tamou, C., Ripoll-Bosch, R., de Boer, J.M.I., Oosting, J.S., 2016b. Traditional ecological knowledge underlying herding decisions of pastoralists. Manuscript submitted for publication.

Tamou, C., Ripoll-Bosch, R., Oosting, S.J., 2015. Drivers of the competing use of land: the case study of the peripheral zone of the National Park W, Benin Republic, in: Conington, J., Klopčič, M., Lauridsen, C., Pollott, G., Santos, A., Sauerwein, H., Simianer, H., Spoolder, H., Tichit, M., van Duinkerken, G., Vangen, O. (Eds.), Book of Abstracts of the 66th Annual Meeting of the European Federation of Animal Science. Wageningen Academic Publishers, Wageningen, The Netherlands, pp. 338.

Tang, R., Gavin, M.C., 2016. A classification of threats to traditional ecological knowledge and conservation responses. Conservation and Society 14, 57-70.

Tarhule, A., 2005. Damaging Rainfall and Flooding: The Other Sahel Hazards. Climatic Change 72, 355-377.

Tessema, Z., De Boer, W., Baars, R., Prins, H., 2011. Changes in soil nutrients, vegetation structure and herbaceous biomass in response to grazing in a semi-arid savanna of Ethiopia. Journal of Arid Environments 75, 662-670.

Tessema, Z.K., de Boer, W.F., Baars, R.M.T., Prins, H.H.T., 2012. Influence of Grazing on Soil Seed Banks Determines the Restoration Potential of Aboveground Vegetation in a Semi-arid Savanna of Ethiopia. Biotropica 44, 211-219.

Thébaud, B., Batterbury, S., 2001. Sahel pastoralists: opportunism, struggle, conflict and negotiation. A case study from eastern Niger. Global Environmental Change 11, 69-78.

Thompson, G.G., Withers, P.C., 2003. Effect of species richness and relative abundance on the shape of the species accumulation curve. Austral Ecology 28, 355-360.

Thompson, K., Grime, J.P., 1979. Seasonal Variation in the Seed Banks of Herbaceous Species in Ten Contrasting Habitats. Journal of Ecology 67, 893-921.

Thornton, P., Van de Steeg, J., Notenbaert, A., Herrero, M., 2009. The impacts of climate change on livestock and livestock systems in developing countries: A review of what we know and what we need to know. Agricultural systems 101, 113-127.

Thornton, P.K., 2010. Livestock production: recent trends, future prospects. Philosophical Transactions of the Royal Society B: Biological Sciences 365, 2853-2867.

Tilman, D., 2001. Functional diversity. Encyclopedia of biodiversity 3, 109-120. 
Tilman, D., Lehman, C., 2001. Human-caused environmental change: Impacts on plant diversity and evolution. Proceedings of the National Academy of Sciences 98, 5433-5440.

Todd, S.W., Hoffman, M.T., 1999. A fence-line contrast reveals effects of heavy grazing on plant diversity and community composition in Namaqualand, South Africa. Plant Ecology 142, 169178.

Tongway, D.J., Ludwig, J.A., 2005. Heterogeneity in Arid and Semiarid Lands, in: Lovett, G.M., Turner, M.G., Jones, C.G., Weathers, K.C. (Eds.), Ecosystem Function in Heterogeneous Landscapes. Springer New York, New York, NY, USA, pp. 189-205.

Toutain, B., Visscher, M.-N.D.E., Dulieu, D., 2004. Pastoralism and Protected Areas: Lessons Learned from Western Africa. Human Dimensions of Wildlife 9, 287-295.

Tresoldi, G., Schütz, K.E., Tucker, C.B., 2016. Assessing heat load in drylot dairy cattle: Refining onfarm sampling methodology. Journal of Dairy Science 99, 8970-8980.

Tsegaye, D., Moe, S.R., Vedeld, P., Aynekulu, E., 2010. Land-use/cover dynamics in Northern Afar rangelands, Ethiopia. Agriculture, Ecosystems \& Environment 139, 174-180.

Turner, M.D., 1999. No space for participation: pastoralist narratives and the etiology of park-herder conflict in southeastern Niger. Land Degradation \& Development 10, 345-363.

Turner, M.D., Ayantunde, A.A., Patterson, K.P., Patterson, E.D., 2011. Livelihood Transitions and the Changing Nature of Farmer-Herder Conflict in Sahelian West Africa. J Dev Stud 47, 183-206.

Turpie, J.K., Marais, C., Blignaut, J.N., 2008. The working for water programme: Evolution of a payments for ecosystem services mechanism that addresses both poverty and ecosystem service delivery in South Africa. Ecological Economics 65, 788-798.

UNEP, 2008. Carbon in drylands: Desertification, climate change and carbon finance. Istanbul: A UNEP- UNDP-UNCCD Technical Note for Discussions at CRIC 7. 03-14 November, 2008.

Van der Zijpp, A.J., 2011. Special Issue: Assessment for Sustainable Development of Animal Production Systems. Livestock Science 139, 1-2.

Van Langevelde, F., Van De Vijver, C.A.D.M., Kumar, L., Van De Koppel, J., De Ridder, N., Van Andel, J., Skidmore, A.K., Hearne, J.W., Stroosnijder, L., Bond, W.J., Prins, H.H.T., Rietkerk, M., 2003. Effects of fire and herbivory on the stability of savanna ecosystems. Ecology 84, 337-350.

Vandvik, V., Klanderud, K., Meineri, E., Måren, I.E., Töpper, J., 2016. Seed banks are biodiversity reservoirs: species-area relationships above versus below ground. Oikos 125, 218-228.

Viera, A.J., Garrett, J.M., 2005. Understanding interobserver agreement: the kappa statistic. Family Medicine 37, 360-363.

Walsh, M., 2012. 'The not-so-Great Ruaha and hidden histories of an environmental panic in Tanzania. Journal of Eastern African Studies 5, 303-335.

Walther, O., 2009. A mobile idea of space. Traders, patrons and the cross border economy in Sahelian Africa. Journal of Borderlands Studies 24, 34-46.

Whitford, W.G., 2002. Ecology of Desert Systems. Academic, London, UK.

Williams, P.R., Congdon, R.A., Grice, A.C., Clarke, P.J., 2005. Germinable soil seed banks in a tropical savanna: seasonal dynamics and effects of fire. Austral Ecology 30, 79-90.

Worthington, R., Bigalke, R., 2001. A review of the infectious diseases of African wild ruminants. The Onderstepoort journal of veterinary research 68, 291-323.

Wu, N., Ismail, M., Joshi, S., Yi, S.-l., Shrestha, R.M., Jasra, A.W., 2014. Livelihood diversification as an adaptation approach to change in the pastoral Hindu-Kush Himalayan region. Journal of Mountain Science 11, 1342-1355.

Wynne-Jones, S., 2013. Connecting payments for ecosystem services and agri-environment regulation: An analysis of the Welsh Glastir Scheme. Journal of Rural Studies 31, 77-86.

Yang, W., Liu, W., Viña, A., Luo, J., He, G., Ouyang, Z., Zhang, H., Liu, J., 2013. Performance and prospects of payments for ecosystem services programs: Evidence from China. Journal of Environmental Management 127, 86-95.

Young, H., Behnke, R., Sulieman, H., Robinson, S., Mohamed, A., 2016. Risk, Resilience, and Pastoral mobility. Feinstein International Center. Somerville, MA, USA. http://fic.tufts.edu/assets/TUFTS_1611_Risk_Resilience_mobility_V6_online.pdf 


\section{References}

Youssao, A.I., Assogba, M., 2002. Prévalence de la fasciolose bovine dans la vallée du fleuve Niger au Bénin. Revue d'élevage et de médecine vétérinaire des pays tropicaux 55, 105-108.

Zuur, A.F., Ieno, E.N., Walker, N.J., Saveliev, A.A., Smith, G.M., 2009. GLM and GAM for Count Data, in: Zuur, A.F., Ieno, E.N., Walker, N.J., Saveliev, A.A., Smith, G.M. (Eds.), Mixed effects models and extensions in ecology with R. Springer, New York, USA, pp. 209-243. 
Samenvatting

\section{Samenvatting}

De competitie om land, speciaal die tussen pastoralisten en landbouwers, maar ook die tussen pastoralisten en natuurbeschermingsinstituties is een bron van zorg een een oorzaak van conflicten geworden. De Biosphere Reserve W (WBR) in de republiek Benin en het omringende land liggen in de zogenaamde agro-pastorale contactzone in West Afrika, hetgeen betekent dat het land zowel voor landbouw als voor pastoralisme geschikt is en dat er, derhalve, competitie om land mogelijk is. In, en speciaal in de periferie van de WBR, wordt de natuurlijke vegetatie (grasland) vervangen door landbouwgewassen. Dit betekent niet alleen een verlies van graslanden met een specifieke biodiversiteit, maar het kan ook een effect hebben op het pastoralisme als systeem. Veranderingen in het systeem van pastoralisme kunnen leiden tot verlies van traditionele ecologische kennis (TEK). Daarnaast kan het de bijdrage van pastoralisten aan het in stand houden van diversiteit in lokale veerassen onder druk zetten. Om de sociaal-economische en ecologische voordelen van pastoralisme te behouden is het van belang om pastoralisten en hun relatie met hun veranderende omgeving te begrijpen. De doelstelling van dit proefschrift was dan ook om de relaties tussen pastoralisten en hun veranderende natuurlijke omgeving te begrijpen.

De eerste stap op weg naar het begrijpen van deze relaties is om inzicht te krijgen in de drijfveren van de veranderingen van het landgebruik en de competitie om land in en rondom de WBR. De doelstelling van hoofdstuk 2 was dan ook om een beschrijving en analyse te geven van i) de veranderingen van het landgebruik om de drijfveren ervan te begrijpen en ii) de standpunten van belangrijke belanghebbenden om de competitie om land in en rondom de WBR te begrijpen. Ik verzamelde kwantitatieve en kwalitatieve gegevens over het landgebruik. Het areaal landbouwgrond rondom de WBR nam toe, terwijl het areaal grasland afnam. Bevolkingsgroei en toenemende vraag naar voedsel- en commerciële gewassen, aangezwengeld door overheidssteun aan de katoensector, waren indirecte redenen van de afname van het grasland. Conflicterende aanspraken op land bestonden tussen landbouwers en pastoralisten, tussen landbouwers onderling en tussen landbouwers, pastoralisten en de WBR-autoriteiten vanwege verdrijving van het land in het verleden, onrechtvaardige en onvolledige implementatie van de WBRregelgeving en de veranderende levenswijze van pastoralisten. De resultaten van 
Samenvatting

hoofdstuk 2 suggereren dat pastoralisme bedreigd is en dat het voortbestaan ervan afhankelijk is van beleid om graslanden te beschermen.

Om vervolgens het effect van pastoralisme op plantengemeenschappen te bestuderen bepaalde ik in hoofdstuk 3 het effect van een lage (L) of hoge (H) begrazingsintensiteit op de botanische diversiteit in de bovengrondse vegetatie en in de zaadopslag in de bodem. Het doel van hoofdstuk 3 was om te evalueren of het huidige begrazingsregime in het grensgebied van en in de WBR een negatief effect heeft op de plantengemeenschappen door de volgende subdoelstellingen aan de orde te stellen: i) het bepalen van het effect van begrazingsintensiteit op de hoeveelheid planten en de soortenrijkdom in de bovengrondse vegetatie, ii) het bepalen van het effect van begrazingsintensiteit op de hoeveelheid zaden in en de soortenrijkdom van de zaadopslag in de bodem en iii) het bepalen van het effect van begrazingsintensiteit op de overeenkomst tussen het voorkomen van soorten in bovengrondse vegetatie en in de zaadopslag in de bodem. Ik maakte een inventarisatie van planten in de bovengrondse vegetatie voor $\mathrm{L}$ en $\mathrm{H}$ op 8 bemonsteringsplekken. Een potexperiment met een gerandomiseerde blokopzet werd gebruikt om de ontkieming van zaden uit de bovenste en iets diepere lagen van de bodem te bepalen. Monsters hiervoor werden verzameld op dezelfde plaatsen als waar de inventarisatie van de bovengrondse vegetatie was gedaan. In de bovengrondse vegetatie vergrootte begrazing de soortenrijkdom, speciaal die van kruidige planten. In de zaadbank in de bodem vergrootte begrazing de hoeveelheid planten, de hoeveelheid kruidige planten en vlinderbloemige bomen en slechts de soortenrijkdom van kruidige planten en vlinderbloemige bomen. Er ontkiemden meer planten uit de bovenste dan uit de diepere bodemlaag. Eénjarige soorten domineerden de bovengrondse vegetatie en de zaadopslag in de bodem. Er werd een groot verschil vastgesteld tussen soorten die voorkomen in de bovengrondse vegetatie en in de zaadopslag in de bodem. De resultaten van hoofdstuk 3 laten zien dat de huidige mate van begrazing de soortenrijkdom in de WBR verhoogt en dat herintroductie van meerjarige soorten in de graslanden humane interventie nodig kan hebben.

Vervolgens betekent hoeden van vee dat er beslissingen genomen moeten worden omdat er getrokken wordt met vee op zoek naar voer. Beslissingen ten aanzien van het hoeden van vee zijn gebaseerd op vaststelling van karakteristieken van bodem, 
Samenvatting

ruwvoer en vee. Als we begrijpen hoe dergelijke karakteristieken zich verhouden tot plaats en moment van het hoeden van het vee krijgen we inzicht in hoe pastoralisten natuurlijke bronnen gebruiken en dat kan vervolgens de mogelijkheid bieden voor duurzame landgebruiksplanning en graslandbeheer. Hoofdstuk 4 had daarom de volgende doelstellingen: i) inventariseren en vaststellen hoe pastoralisten de kwaliteit van bodem en ruwvoerders in hun omgeving karakteriseren, ii) analyseren hoe bodem-, ruwvoer- en veekarakteristieken zich verhouden tot beslissingen over het hoeden van vee en iii) vast te stellen of TEK die bijdraagt aan beslissingen over het hoeden van vee verschilt tussen generaties. Informatie werd verzameld door middel van focusgroepdiscussies en individuele interviews met 72 pastoralisten, verspreid over drie generaties en uit drie verschillende agro-ecologische zones. Met behulp van een schaal met drie niveaus (hoog, medium, laag), werd de voedingswaarde voor melk- en vleesproductie, gezondheid en uithoudingsvermogen van vier grassen en drie van bomen en struiken afkomstige ruwvoeders vastgesteld. Op basis van door henzelf vastgestelde visuele criteria bleek dat de pastoralisten vijf bodemtypen onderscheidden, die ze selecteerden in verschillende jaargetijden. Pokuri was het beste bodemtype vanwege de goede drainage-eigenschappen, terwijl Karaal het slechtste bodemtype was omdat er nauwelijks ruwvoer op groeit. Meerjarige planten zoals Andropogon gayanus en Loxoderra ledermannii hadden een hoge voederwaarde maar aan de éénjarige Andropogon pseudapricus en Hyparrhenia involucrata werd een lage voedingswaarde toegeschreven. Afzelia africana had een goede voederwaarde voor melkproductie, terwijl Khaya senegalensis de beste voederwaarde had voor vleesproductie, gezondheid en uithoudingsvermogen. Pastoralisten gebruikten eerst bodem-, daarna ruwvoer- en uiteindelijk veekarakteristieken om hun beslissingen over het hoeden van vee te nemen, een gestructureerde redenering met duidelijke voorkeuren. De TEK van pastoralisten verschilde niet tussen generaties, maar wel tussen agro-ecologische zones. Deze studie liet zien dat pastoralisten een holistische benadering hebben waarin ze TEK over bodem, vegetatie en vee combineren. Dergelijke TEK kan een leidraad zijn voor herstel of verbetering van graslanden en van landgebruiksplanning.

Uiteindelijk kan gesteld worden dat pastoralisme geconfronteerd wordt met verlies en fragmentatie van graasgebieden, hetgeen hun productiesysteem negatief kan 
Samenvatting

beïnvloeden. Verandering in het pastorale productiesysteem kan leiden tot veranderingen in gewenste vee-eigenschappen, hetgeen op zijn beurt weer kan resulteren in verlies van lokale veerassen. Het begrijpen van de perceptie van pastoralisten ten aanzien van lokale veerassen en de eigenschappen van deze rassen is van belang om verlies van diversiteit van vee te voorkomen en om toekomstige productiesystemen te verbeteren. De doelstellingen van hoofdstuk 5 waren: i) een inventarisatie te maken van lokale koeienrassen en hun prestaties op een aantal eigenschappen, ii) te analyseren wat de voorkeuren van pastoralisten waren voor verschillende koeienrassen en de redenen van deze voorkeuren en iii) vast te stellen of de kennis over koeienrassen en eigenschappen van deze rassen overgegeven werd van de ene generatie aan de andere en of de kennis consistent was tussen agroecologische zones. Informatie werd verzameld door middel van focusgroepdiscussies en individuele interviews met 72 pastoralisten. De geïnterviewden behoorden tot drie generaties en bewoonden drie agro-ecologische zones in de periferie van de WBR. Vanuit de focusgroepdiscussies identificeerden we de meest voorkomende koeienrassen in de regio (nl. Keteeji, Jaliji, Bodeeji, Tchiwali en Gudali) en de belangrijkste eigenschappen (nl. melkproductie, vleesproductie, uithoudingsvermogen om te lopen en tolerantie tegen trypanosomiasis) om de rassen op te evalueren volgens de pastoralisten. Daarna scoorden de individuele geïnterviewden de prestatie van de koeienrassen wat de vier eigenschappen betreft op een driepuntenschaal (hoog, medium en laag). Uiteindelijk bepaalden we de consistentie van deze kennis van pastoralisten vast tussen generaties en tussen agro-ecologische zones. Keteeji werd gewaardeerd voor zijn uithoudingsvermogen en tolerantie tegen trypanosomiasis, Bodeeji werd gewaardeerd voor zijn uithoudingsvermogen en Gudali werd gezien als van hoge waarde voor melk- en vleesproductie, maar van een lage waarde voor uithoudingsvermogen. Keteeji was het meest geliefde koeienras van de meerderheid van de pastoralisten (bijna 50\%), in het bijzonder vanwege het aanpassingsvermogen (bijvoorbeeld het kunnen doorstaan van honger) en niet vanwege de productie-eigenschappen. Gudali was het minst gewaardeerde ras (11\%). Tachtig procent van de pastoralisten verkoos het meest gewenste ras op basis van niet-productie-eigenschappen zoals het kunnen doorstaan van honger, intelligentie (om de herder te gehoorzamen) of weerstand tegen ziekte. Deze studie liet zien dat pastoralisten aanpassingsvermogen belangrijker vonden dan productieeigenschappen van koeienrassen om zo om te kunnen gaan met de veranderende en 
ongunstige omstandigheden in hun leefomgeving. De kennis van pastoralisten over de eigenschappen van de koeien verschilde niet tussen generaties, maar er waren enkele verschillen tussen agro-ecologische zones.

In hoofdstuk 6 werd de toekomst van pastoralisme bediscussieerd op basis van de resultaten van de voorafgaande hoofdstukken. Deze discussie liet zien, dat, met het voortschrijdende verlies van graasgebieden, en afhankelijk van de omvang van de veestapel van de pastoralisten, er drie strategieën te bedenken zijn: hanging-in, stepping-up en stepping-out. Van deze drie strategieën lijkt de stepping-up onwaarschijnlijk. Arme pastoralisten zullen de hanging-in strategie waarschijnlijk benutten op de korte of middenlange termijn, hetgeen inhoudt dat ze vasthouden aan mobiliteit in het hoeden van vee, maar dan op marginale graslanden in combinatie met kleinschalige gewasproductie. Het is echter waarschijnlijk dat deze strategie op de lange termijn niet duurzaam is en dat de arme pastoralisten hun activiteiten zullen opgeven (stepping-out) en zelfs het gebied kunnen gaan verlaten (bijvoorbeeld naar stedelijke of peri-urbane gebieden zullen migreren). Rijkere pastoralisten zullen mogelijk al eerder de regio verlaten, waar vanwege de omvang van hun kuddes (hun rijkdom) onvoldoende voer is in de huidige situatie. Uiteindelijk zullen sommigen van de rijkere pastoralisten de stepping-out strategie volgen door zich met veehandel bezig te gaan houden, om zo de stedelijke gebieden in het land te voorzien, maar ook de steden in Nigeria. Twee mogelijke institutionele interventies zouden pastoralisme in de regio kunnen behouden. Deze interventies zijn i) betalingen voor levering van ecosysteemdiensten door de pastoralisten, bijvoorbeeld in de vorm van landgebruiksrechten en economische ondersteuning aan landeigenaren die land uitlenen aan pastoralisten en ii) associaties tussen pastoralisme en natuurbehoud in zogenaamde pastorale bufferzones. In de praktijk zal implementatie van deze interventies echter zeer moeilijk zijn. Uiteindelijk concludeert de discussie dat er op de lange termijn maar weinig opties zijn om pastoralisme te behouden, hetgeen impliceert dat op de korte tot middenlange termijn de kwetsbaarheid van pastoralisten en hun leefwijze zal toenemen. 


\section{Acknowledgements}

The accomplishment of this PhD thesis would not have been possible without the invaluable contribution of a number of organisations and people that have supported me during all these years. I am very grateful to these organisations and people, and I would hence like to acknowledge them in this section.

This thesis was funded by the Netherlands organisation for international cooperation in higher education (NUFFIC) and the Animal Production Systems (APS) group of Wageningen University \& Research. I would like to thank both organisations for their generous support. To Wageningen University \& Research, I am grateful for the excellent facilities at Forum, including the Library, and the office at the APS group, which have been exciting environments for my research and scholarly pursuit. I will always miss these environments.

Apart from these organisations (hardware), a PhD study requires software, people with intellectual background and scientific rigor, to nurture and guide the PhD work. First, I would like to thank my promotor Prof. Dr Imke J.M. de Boer, who accepted my PhD application at the Animal Production Systems group. Your encouragement, guidance and invaluable contribution in all the chapters, despite your busy planning, were determinant in the finalisation of this thesis.

Next I would like to thank my daily supervisor Dr. Simon J. Oosting for the inspiring suggestions, encouragement, his availability at any time and his patience. You have been a very human support to all my requests during these years and I was very lucky to have you at my side.

To my co-supervisor Dr. Raimon Ripoll-Bosch, I am grateful for your critical comments, suggestions and advice. As my officemate, I really appreciate your (close) encouragement and your humour that relieved me, when everything looked very dark.

I thank Prof. Issiaka Youssao Abdou Karim for being my 'home supervisor', for allowing me to complete my $\mathrm{PhD}$ application documents, and for encouraging me and for contributing useful discussions.

At the APS group, I am indebted to Fokje Steenstra for statistical assistance and for formatting this thesis for printing, Laura Webb for critical reading and improving the 
Acknowledgements

English, Akke Kok (my beloved Dutch sister) for critical reading of some papers, and Hannah for being a perfect officemate. I am also grateful to Ymkje Tamminga for her support during sad events that spoiled my PhD journey. I would like to thank people of APS for the pleasant environments they contributed to: Eddy, Theo, Kees, Corina, Heleen, Linda, Steven, Kebebe, Avhafunani, Sally, Aart, Iris, Brain, Cindy, Simon, Edit, Nicole, Abigail, Windi, David and Eliza. I would also like to thank Paul for his inspiring suggestions in selecting the propositions belonging to this thesis.

I experienced my PhD study as a journey, a long and hard one. Thinking back, my PhD journey started with a friend and colleague Dr. Latifou Idrissou, who visited me when I was field officer in a forest restoration project in Benin. I am grateful to you for suggesting and encouraging me to do a PhD. I would also like to thank Dr. Guiriguissou A. Maboudou and Dr. Augustin Kouevi for accommodating me during my first visit in Wageningen to meet Prof. Imke J.M. de Boer and Dr. Simon J. Oosting. I would like to thank Dr. Gaoue Orou Gande, Dr. Ismael Moumouni, Dr. Honore Biaou and Dr. Armand Natta for useful discussions and for their encouragement. Also many thanks to Doortje, the Dutch-Beninese, for the Beninese dinners she prepared for Beninese students, to Djalal, Soule, Nathalie, Edmond, Akpo, Euloge, Nicodeme, Harold, Fola, Waliou, Faly, Jonas, Olga, Raoul for their friendship, advice and the nice times we had during these years in Wageningen.

I am also grateful to people who assisted me, in all kinds of ways, during my field work. I would like to mention the authorities of the $\mathrm{W}$ Biosphere Reserve, the AVIGREF members, the Fulbe leaders and pastoralists, and crop farmers whom I interviewed. I am mostly grateful to Boni Yacoubou for assistance in botanical identification and useful discussions, to Nassirou Orou N'goye (my field assistant) for Fulfulde translation, to Kader Chabi Touri for accommodation and useful discussions, and to Mathieu for taking care of the soil seed bank experiment, and also to Hakirou, Gado, Soule, Zakou, Amidou, Seidou for guidance on the field work and providing accommodation. Thank you very much!

This thesis would not have been possible without the unconditional love, sacrifice and encouragement of my wife Zoubera. And my sons: Yarou, Guera and Sacca, please consider this thesis as the reason of my long absence, that I hope you have understood and have accepted. You missed me during these years, and I missed you too. I hope this thesis will express my deep gratitude to you. 
Acknowledgements

Finally, to my late father and mother, who both passed away during my PhD study, I wish to express my sincerest thanks. My appreciation to my late mother for schooling me, and my appreciation to my late father for encouraging me to pursue this hard, yet exciting journey.

Parakou (Benin), March 14 $4^{\text {th }}, 2017$

Charles Tamou 


\section{About the author}

Charles Tamou was born on March $3^{\text {rd }}, 1976$ in Banikoara (northern Benin). In 1996, after his secondary school (levels I and II), he entered the University of AbomeyCalavi (former National University of Benin) where he studied Chemistry-BiologyGeology at the Faculty of Sciences and Technics. In 1997, he left this faculty after he was awarded a national scholarship to study at the Faculty of Agricultural Sciences, where he obtained his Agricultural Engineer degree in 2002, with focus on rangeland ecology and transhumant pastoralism. He conducted his fieldwork in the peripheral zone of the W Biosphere Reserve (former W National Park), with the financial support of the ECOPAS project (Ecosystèmes Protégés en Afrique SoudanoSahélienne). After two years of working as assistant researcher at the Laboratory of Applied Ecology of the Faculty of Agricultural Sciences, he worked for development projects in Benin, such as the Forests' Restoration project (PAMF), the Root and Tubers project (PDRT), and the African Development Foundation of USA (USADF) partnership for funding community-based organisations. In 2010, he was awarded a scholarship from the CUD (Coopération Universitaire pour le Développement) for an Advanced Master (Master complémentaire) in Liege, Belgium in animal and plant resource management in the tropics. In 2011 he graduated for this Advanced Master (with grande distinction) at Gembloux AgroBioTech, University of Liege. He studied the dynamics of livestock market development in Benin: the case study of the village of Alibori B. In 2012, he was awarded a fellowship from the Netherlands organisation for international cooperation in higher education (NUFFIC) for a PhD study at the Animal Production Systems group of Wageningen University. His PhD study focussed on pastoralism and its changing environment in and around the $\mathrm{W}$ Biosphere Reserve. Results of his work have been presented at the $66^{\text {th }}$ Annual meeting of European Federation of Animal Production (EAAP) in 2015 and at the Tropentag 2015. Manuscripts related to the chapters of his $\mathrm{PhD}$ thesis have been submitted to peer-reviewed scientific journals.

Charles Tamou's research interests include grassland ecology, pastoralism and its related domains such as traditional ecological knowledge, management of socialecological system and livestock biodiversity.

Author's email is: tamouc@gmail.com 


\section{Publications}

\section{Articles in peer-reviewed scientific journals}

Tamou, C., Ripoll-Bosch, R., de Boer, I.J.M., Oosting, S.J., 2016. Pastoralists in a changing environment: the competition for grazing land in and around the W Biosphere Reserve, Benin Republic. Under revision AMBIO. A journal of the Human Environment

Tamou, C., de Boer, I.J.M., Ripoll-Bosch, R., Oosting, S.J., 2017. Understanding traditional ecological knowledge underlying herding decisions of pastoralists. Under revision Animal. The International Journal of Animal Biosciences

Tamou, C., de Boer, I.J.M., Ripoll-Bosch, R., Oosting, S.J., 2017. Understanding roles and functions of cattle breeds for pastoralists in Benin. Submitted

Tamou, C., Ripoll-Bosch, R., de Boer, I.J.M., Oosting, S.J., 2017. Effect of grazing on aboveground vegetation and soil seed banks in the W Biosphere Reserve, Benin Republic. Submitted

\section{Abstracts in conference proceedings}

Tamou, C., Ripoll-Bosch, Oosting, S.J., 2015. Drivers of the competing use of land: the case study of the peripheral zone of the National Park W, Benin Republic. In: Book of Abstracts of the 66th Annual Meeting of the European Federation of Animal Science. Warsaw, Poland, p. 338

Tamou, C., Ripoll-Bosch, R., de Boer, I.J.M., Oosting, S.J., 2015. Competing land use in the area of the W Biosphere Reserve, Benin Republic. In: Book of Abstracts of the Tropentag 2015. Berlin, Germany, p. 36

Tamou, C., Ripoll-Bosch, R., de Boer, I.J.M., Oosting, S.J., 2016. Traditional knowledge about local breeds of cattle across generations of Fulbe pastoralists around the W Biosphere Reserve in Benin. Presented at WIAS Science Day 2016, Wageningen University (The Netherlands)

Tamou, C., de Boer, I.J.M., Ripoll-Bosch, R., Oosting, S.J., 2017. The future of indigenous cattle breeds of pastoralists in Benin. Accepted to be presented at 68th Annual Meeting of the European Federation of Animal Science, Tallinn, Estonia 


\section{WIAS Education certificate}

\section{Completed training and supervision plan ${ }^{1}$}

\section{The Basic Package (3 ECTS)}

WIAS introduction course, Wageningen, October 2012

Ethics and Philosophy in Life Sciences Wageningen, November 2015

\section{International conferences (2.7 ECTS)}

Annual Meeting of the European Association for Animal Production, Warsaw, August-September 2015

Trogentag, Berlin, September 2015

\section{Seminars and workshops (o.9o ECTS)}

WIAS Science Day, Wageningen, February 2013

Family Farming workshop organised by WaCASA, Wageningen, May 2014

WIAS Science Day, Wageningen, February 2016

\section{Presentations (5 ECTS)}

Oral presentation at Annual Meeting of the European Association for Animal Production (2015)

Poster presentation at Tropentag (2015)

Oral presentation at WaCASA meetings (2016)

Poster presentation at WIAS Science Day (2016)

Oral presentation (invited speaker) Course on Sustainability assessment of animal systems (2016)

\section{In-Depth Studies (10 ECTS)}

Tropical livestock farming system research and development, February 2013

Making an Impact - How to increase the societal relevance of your PhD research, May 2016

WIAS Advanced Statistics Course Design of Experiments, October 2012

Ecological modelling in R (MSc course), October-December 2012

Professional Skills Support Courses (4.2 ECTS)

Project and Time Management (P\&TM), January- February 2013

Information Literacy including EndNote Introduction (ILP), June 2014

WGS PhD Workshop Carousel, June 2014

Course Techniques for Writing and presenting a scientific paper, October 2015

Brain training, March 2016

WGS PhD Workshop Carousel, April 2016

\section{Research Skills Training (7.8 ECTS)}

Preparing own $\mathrm{PhD}$ research proposal

Understanding of statistical analysis with R, Parakou (Benin), July 2013

\section{Total: 33.60 ECTS}

1With the activities listed, the PhD candidate has complied with the requirements set by the Graduated School of Wageningen University Institute of Animal Science (WIAS). One ECTS equals a study load of 28 hours. 


\section{Colophon}

The research described in this thesis was financially supported by the Netherlands University Foundation for International Cooperation (NUFFIC) and the Animal Production Systems group of Wageningen University. The Dr Judith Zwartz foundation contributed to the covering of the printing costs.

Cover drawing by Zoulkifouli Gbadamassi, Phone: (+229) 97102638, Benin Republic.

Printed by ProefschriftMaken, Vianen 